NUREG-1522

\title{
Assessment of Inservice Conditions of Safety-Related Nuclear Plant Structures
}

\section{U.S. Nuclear Regulatory Commission}

Office of Nuclear Reactor Regulation

H. Ashar, G. Bagchi
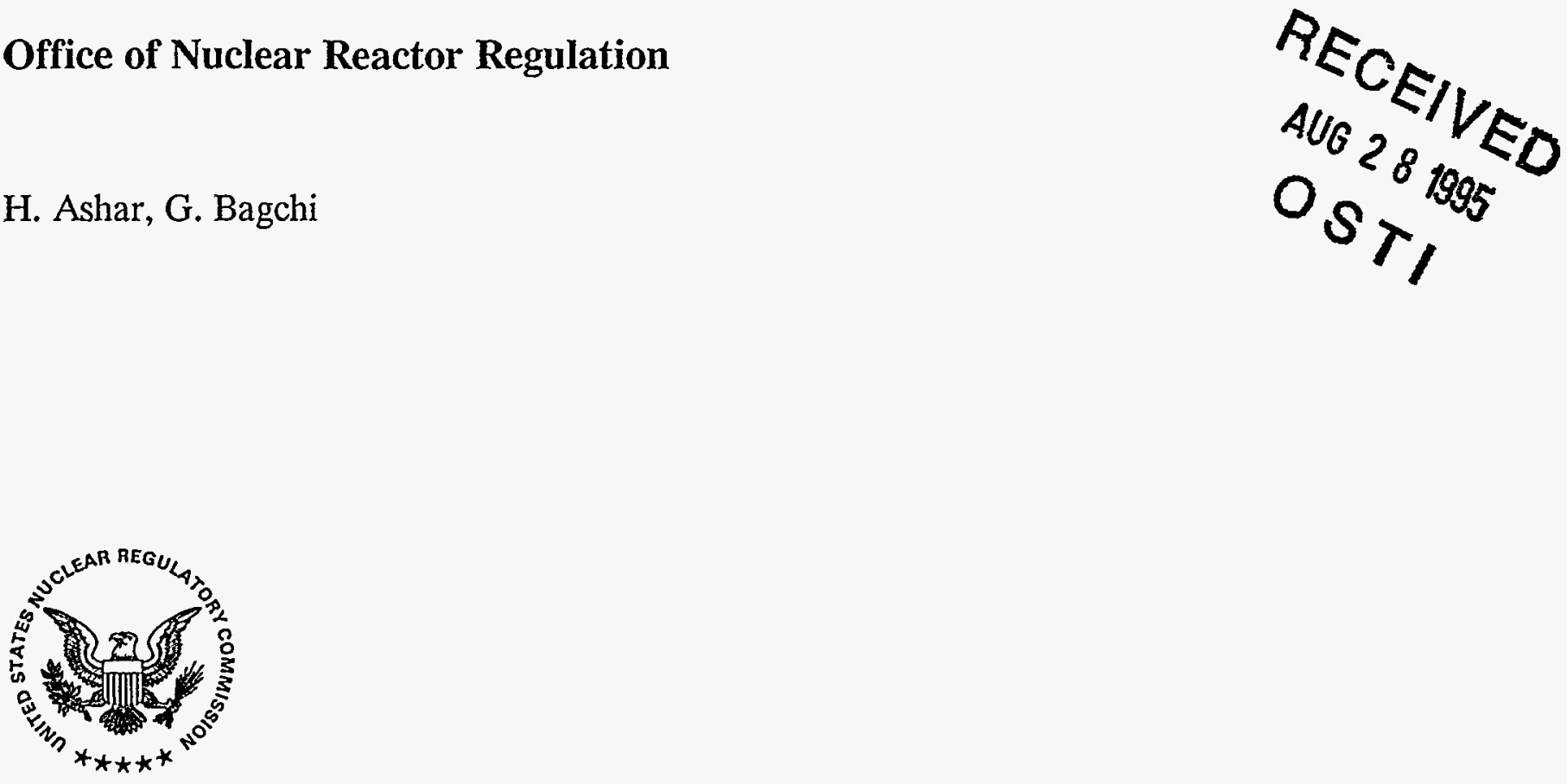


\section{AVAILABILITY NOTICE}

\section{Availability of Reference Materials Cited in NRC Publications}

Most documents cited in NRC publications will be available from one of the following sources:

1. The NRC Public Document Room, 2120 L Street, NW., Lower Level, Washington, DC 20555-0001

2. The Superintendent of Documents, U.S. Government Printing Office, P. O. Box 37082 , Washington, DC 20402-9328

3. The National Technical Information Service, Springfield, VA 22161-0002

Although the listing that follows represents the majority of documents cited in NRC publications, it is not intended to be exhaustive.

Referenced documents available for inspection and copying for a fee from the NRC Public Document Room include NRC correspondence and internal NRC memoranda; NRC bulletins, circulars, information notices, inspection and investigation notices; licensee event reports; vendor reports and correspondence; Commission papers; and applicant and licensee documents and correspondence.

The following documents in the NUREG series are available for purchase from the Government Printing Office: formal NRC staff and contractor reports, NRC-sponsored conference proceedings, international agreement reports, grantee reports, and NRC booklets and brochures. Also available are regulatory guides, NRC regulations in the Code of Federal RegulatJons, and Nuclear Regulatory Commission Issuances.

Documents available from the National Technical Information Service include NUREG-series reports and technical reports prepared by other Federal agencies and reports prepared by the Atomic Energy Commission, forerunner agency to the Nuclear Regulatory Commission.

Documents available from public and special technical libraries include all open literature items, such as books, journal articles, and transactions. Federal Register notices, Federal and State legislation, and congressional reports can usually be obtained from these libraries.

Documents such as theses, dissertations, foreign reports and translations, and non-NRC conference proceedings are available for purchase from the organization sponsoring the publication cited.

Single copies of NRC draft reports are available free, to the extent of supply, upon written request to the Office of Administration, Distribution and Mail Services Section, U.S. Nuclear Regulatory Commission, Washington DC 20555-0001.

Copies of industry codes and standards used in a substantive manner in the NRC regulatory process are maintained at the NRC Library, Two White Flint North, 11545 Rockville Pike, Rockville, MD 20852-2738, for use by the public. Codes and standards are usually copyrighted and may be purchased from the originating organization or, if they are American National Standards, from the American National Standards Institute, 1430 Broadway, New York, NY 10018-3308. 


\section{DISCLAIMER}

This report was prepared as an account of work sponsored by an agency of the United States Government. Neither the United States Government nor any agency thereof, nor any of their employees, make any warranty, express or implied, or assumes any legal liability or responsibility for the accuracy, completeness, or usefulness of any information, apparatus, product, or process disclosed, or represents that its use would not infringe privately owned rights. Reference herein to any specific commercial product, process, or service by trade name, trademark, manufacturer, or otherwise does not necessarily constitute or imply its endorsement, recommendation, or favoring by the United States Government or any agency thereof. The views and opinions of authors expressed herein do not necessarily state or reflect those of the United States Government or any agency thereof. 


\section{DISCLAIMER}

Portions of this document may be illegible in electronic image products. Images are produced from the best available original document. 
NUREG-1522

\section{Assessment of Inservice Conditions of Safety-Related Nuclear Plant Structures}

Manuscript Completed: March 1995

Date Published: June 1995

H. Ashar, G. Bagchi

Division of Engineering

Office of Nuclear Reactor Regulation

U.S. Nuclear Regulatory Commission

Washington, DC 20555-0001

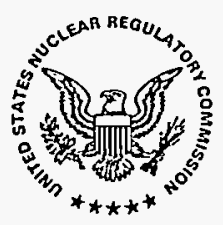


For sale by the U.S. Government Printing Office

Superintendent of Documents, Mail Stop: SSOP, Washington, DC 20402-9328 ISBN $0-16-048149-x$ 


\section{ABSTRACT}

The report is a compilation from a number of sources of information related to the condition of structures and civil engineering features at operating nuclear power plants in the United States. The most significant information came from the hands-on inspection of the six old plants (licensed prior to 1977) performed by the staff of the Civil Engineering and Geosciences Branch (ECGB) in the Division of Engineering of the Office of Nuclear Reactor Regulation. For the containment structures, most of the information related to the degraded conditions came from the licensees as part of the Licensing Event Report System (10 CFR 50.73), or as part of the requirement under limiting condition of operation of the plantspecific Technical Specifications. Most of the information related to the degradation of other structures and civil engineering features was extracted from the industry survey, the reported incidents, and the plant visits.

The report discusses the condition of the structures and civil engineering features at operating nuclear power plants and provides information that would help detect, alleviate, and correct the degraded conditions of the structures and civil engineering features. 



\section{CONTENTS}

Page

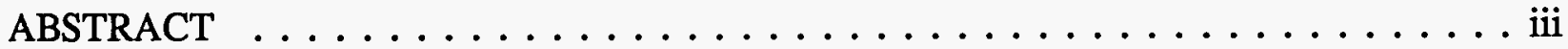

ABBREVIATIONS $\ldots \ldots \ldots \ldots \ldots \ldots \ldots \ldots \ldots \ldots \ldots \ldots \ldots \ldots \ldots \ldots$ vii

EXECUTIVE SUMMARY $\ldots \ldots \ldots \ldots \ldots \ldots \ldots \ldots \ldots \ldots \ldots \ldots \ldots$ ix

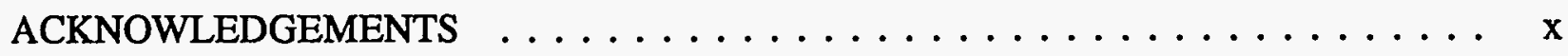

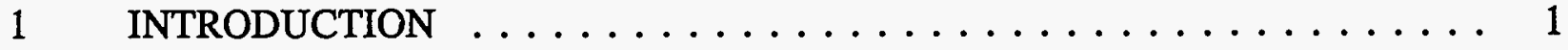

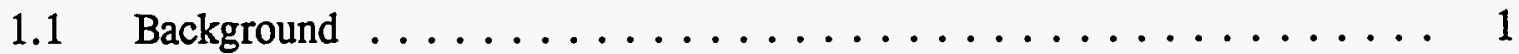

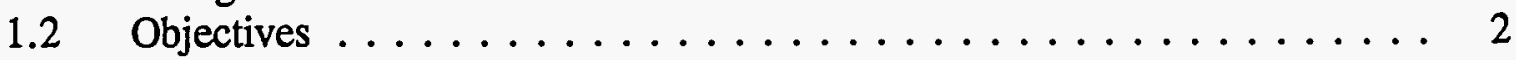

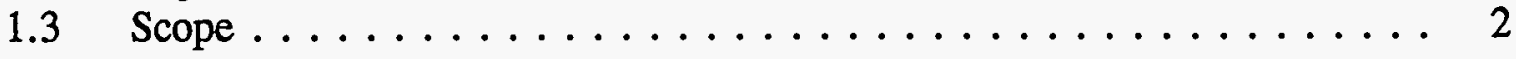

2 DEGRADATION OF CONTAINMENT STRUCTURES $\ldots \ldots \ldots \ldots \ldots .3$

2.1 Reinforced and Prestressed Concrete Containments . . . . . . . . 3

2.2 Steel Containments . . . . . . . . . . . . . . . . 6

3 DEGRADATION OF OTHER STRUCTURES $\ldots \ldots \ldots \ldots \ldots \ldots \ldots$

3.1 Description . . . . . . . . . . . . . . . . 9

3.2 Experience With Structural Degradation ............. 9

4 INSPECTIONS OF SIX PLANTS $\ldots \ldots \ldots \ldots \ldots \ldots \ldots \ldots \ldots$

4.1 Audit-Inspection Process . . . . . . . . . . . . . . 13

4.2 Observations and Findings $\ldots \ldots \ldots \ldots \ldots \ldots \ldots \ldots \ldots \ldots$

4.2.1 Containment Structures . . . . . . . . . . . . . 15

4.2.2 Intake Structure and Pumphouse . . . . . . . . . 15

4.2.3 Other Safety-Related Structures . . . . . . . . . . 15

4.2 .4 Civil Engineering Features $\ldots \ldots \ldots \ldots \ldots \ldots \ldots$

$5 \quad$ FINDINGS . . . . . . . . . . . . . . . . . . . 19

5.1 Containment Structures . . . . . . . . . . . . . . . 19

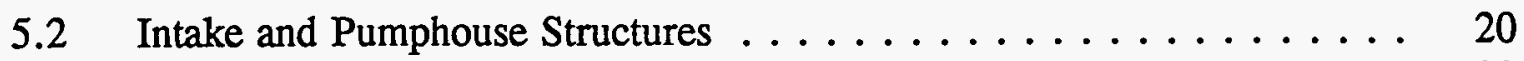

5.3 Other Prestressed Concrete Structures $\ldots \ldots \ldots \ldots \ldots \ldots \ldots$

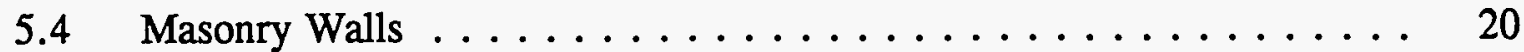

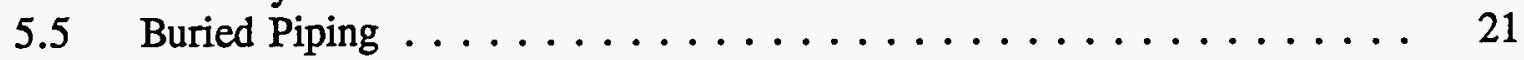

5.6 Settlement of Structures and Seismic Gaps $\ldots \ldots \ldots \ldots \ldots \ldots \ldots 21$

5.7 Safety-Related Water Storage Tanks . . . . . . . . . . . . 21

5.8 Piping and Equipment Anchorage Deficiencies . . . . . . . . . 21

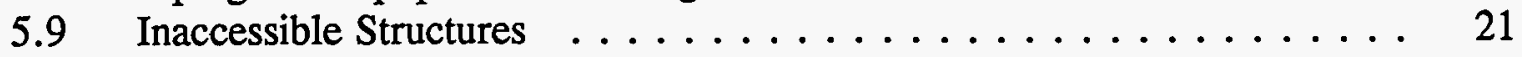


5.10 Evaluations Under 10 CFR $50.59 \ldots \ldots \ldots \ldots \ldots \ldots \ldots \ldots \ldots$

6 OBSERVATIONS AND CONCLUSIONS $\ldots \ldots \ldots \ldots \ldots \ldots \ldots \ldots$

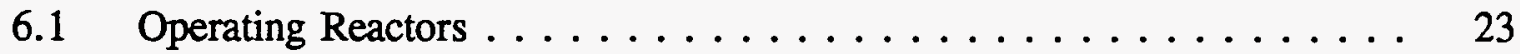

6.2 Future Reactors . . . . . . . . . . . . . . . . . 24

6.3 Conclusions ........................ 25

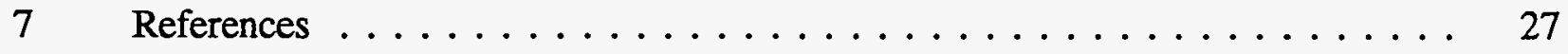

Appendix BNL Technical Report, "Assessment of Aging Degradation of

Civil/Structural Features at Selected Operating Nuclear

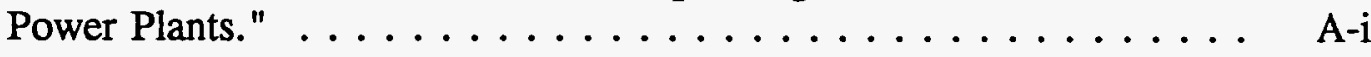




\section{ABBREVIATIONS}

$\mathrm{ACl} \quad$ American Concrete Institute

ASME American Society of Mechanical Engineers

BNL Brookhaven National Laboratory

B\&PV Boiler \& Pressure Vessel (Code)

BWR boiling-water reactor

ECGB Civil Engineering and Geosciences Branch

EPRI Electric Power Research Institute

ESGB Structural and Geosciences Branch

FP\&L Florida Power and Light Co.

IPEEE individual plant examination of external events

NSAC Nuclear Safety and Analysis Center

NUMARC Nuclear Management and Resources Council, Inc.

NEI Nuclear Energy Institute

NRR Office of Nuclear Reactor Regulation

PCC prestressed concrete containment

PDLR License Renewal and Environmental Review Project Directorate

PWR pressurized-water reactor

RCC reinforced-concrete containment

RSIB Special Inspection Branch

SC steel containment

SSCs structures, systems, and components

USGS U.S. Geological Survey 



\section{EXECUTIVE SUMMARY}

The nuclear power plant structures are designed to withstand the low probability natural phenomena and reactor accident loadings, and are constructed utilizing stringent quality control requirements. They are robust and have not been subjected to the low probability challenges for which they are designed except on two occasions: the accident at Three Mile Island, Unit 2, and the fierce wind loadings imposed by Hurricane Andrew on the structures of Units 3 and 4 of Turkey Point Nuclear Station. Structures subjected to the loadings from these events withstood the loads without appreciable damage. However, information on the failures of non-nuclear structures (highway bridge-decks and parking garages) indicates that the age-related degradation of well-designed and properly constructed structures could weaken them sufficiently to cause them to fail without being subjected to abnormal loadings. Several incidents of age-related degradation of the nuclear structures have been reported. This report documents such instances of degradation, indicates their root causes, and suggests preventive and corrective measures.

The report contains information from various sources on the condition of structures and civil engineering features at operating nuclear power plants. The most significant information came from the inspection of the six old plants (licensed before 1977) by the staff of the Civil Engineering and Geosciences Branch (ECGB) in the Division of Engineering of the Office of Nuclear Reactor Regulation. Most of the information on the degraded conditions of containment structures was submitted by the licensees for the Licensing Event Report System (10 CFR 50.73), or in fulfilling the requirement under limiting conditions of operation of technical specifications for their plants. Most of the information on the degradation of other structures and civil engineering features comes from an industry survey, reported incidents, and plant visits.

Industry reports such as Nuclear Management and Resources Council Technical Report 90-06 (NUMARC 1990) on Class I structures and Electric Power Research Institute report NP6041-SL (EPRI 1991) on seismic margin methodology have been quite useful in presenting the industry perspective on various aspects of structural degradation and how it can affect the assessment of structures and civil engineering features. Moreover, this report lists the regulatory documents relevant to the design, inservice tests or inspections, and maintenance of the structures that could be useful in assessing the structures and civil engineering features.

The authors found that the safety-related nuclear power plant structures need to be periodically inspected and maintained. Taking remedial actions to repair concrete cracks and spalls or to recoat corroded steel surfaces is more effective in maintaining structures than performing evaluations to justify postponing correction of degradation until it becomes a safety issue. 


\section{ACKNOWLEDGEMENTS}

The authors acknowledge and appreciate Messrs. Joseph Braverman and Rich Morante of Brookhaven National Laboratory who took meticulous notes and excellent photographs during the plant visits. David Jeng, Robert Rothman, Young Kim, John Ma (NRC, ECGB); HaiBoh Wang (NRC, RSIB); David Tang (NRC, PDLR); Joseph Carasco (NRC, Region I); Joseph Lenahan (NRC, Region II); James Gavula and Jack Gadzala (NRC, Region III); Michael Runyan (NRC, Region IV); and Clifford Clark (NRC, Region V) contributed to this report through their observations and input during and after the plant walkdown inspections. The authors acknowledge and appreciate their valuable contribution. We particularly thank the licensees (Portland General Electric, Wisconsin Electric Power Company, Florida Power and Light Company, Carolina Power and Light, Dusquene Light Company, and Nebraska Public Power District) and their engineering staffs for facilitating the NRC staff's walkdown activities.

Special thanks to Mrs. Serona Mosby (NRC, ECGB) for efficiently typing and compiling the report and to Rayleona Sanders (NRC, ADM) for editing it. 


\section{INTRODUCTION}

\subsection{Background}

As of January 1995, 109 commercial nuclear power reactors are licensed to operate in the United States. Fifty-five operating reactors received their licenses before mid-1976, and fifty-four operating reactors were licensed after mid-1976. The median operating life of the current operating reactors is 18 years.

A number of incidents involving degraded safety-related structures and civil engineering features have been reported in the last 14 years. Incidents of corrosion of steel containments, corrosion of reinforcing bars of intake structures, and grease leakage and low prestressing forces in prestressed concrete containments are known throughout the nuclear industry.

Safety-related structures are designed to withstand loadings from a number of low-probability external and internal events, such as earthquake, tornado, and loss-of-coolant accidents. Consequently, they are robust and are not subjected to high enough stresses during normal operation to cause any appreciable degradation. Hence, the reported incidents of structural degradation are mainly attributable to the combined environmental and age-related effects. But with the increasing age of the operating reactors, more age-related degradations can be expected.

General Design Criterion 53 of Appendix A to Part 50 of Title 10 of the Code of Federal Regulations (10 CFR Part 50) requires that the reactor containment shall be designed to permit its inspection and leak testing. Appendix J to 10 CFR Part 50 requires leak-rate testing of the containment, and a general inspection of the accessible interior and exterior surfaces of the containment before the leak-rate testing. Thus, the regulations explicitly incorporate the inservice inspection requirements for containment structures. Recognizing the potential vulnerabilities of the highly stressed prestressing components of the prestressed concrete containments (PCCs), the staff issued guidance in Regulatory Guides 1.35 and 1.90 for monitoring the vital features of the prestressing systems of the PCCs. Thus, the PCCs of the operating reactors are inspected under an inspection program. Additionally, Regulatory Guide 1.127 provides guidance for developing an appropriate in-service inspection and surveillance program for dams, slopes, canals, and other water-control structures associated with emergency cooling water systems or flood protection of nuclear power plants.

NRC has not issued regulatory requirements or guidance for periodically inspecting the other safety-related structures. However, Section 50.65 of 10 CFR Part 50 requires that plant owners monitor the performance or condition of structures, systems, and components (SSCs), against the owner-established goals, in a manner sufficient to give reasonable assurance that such SSCs are capable of fulfilling their intended functions. Section 50.65 further requires the licensee to take appropriate corrective action when the performance or condition of an SSC does not conform to established goals. 
Other safety-related structures in the context of this report are (1) all structures in a nuclear plant categorized as seismic Category I and (2) those structures that are in seismic Category II or are classified as non-safety-related and whose failure could affect the safety function of safety-related SSCs. Seismic Category I structures are internal structures in the containment, shield wall, and reactor building [boiling-water reactors (BWRs)], shield building [pressurized-water reactors (PWRs)], fuel-handling building (or area), auxiliary or intermediate building, diesel generator building, service water pump-house, intake structure, and turbine building in some plants.

The civil engineering features in the context of this report are (1) the safety-related buried piping, dams, and embankments, canals for water intake or discharge, and facilities for ultimate heat sink and (2) ancillary devices, such as pumps and dehumidifiers, required to reduce water damage and environmental degradation of the structures.

These safety-related structures and civil engineering features are herein called structures.

\subsection{Objectives}

The objectives of this study are to (1) review the known information on the degradation of structures and assess their conditions with respect to their safety functions, (2) make observations as to whether these safety functions are maintained for the life of the plant, and (3) provide information that could be useful for the improved design and construction of structures of the future reactors.

\subsection{Scope}

The staff reviewed relevant licensee event reports, other industry reports, NRC research reports, the results of inservice inspections, and information gathered from staff visits to six older plants. The staff reviewed this information to assess the present condition of the structures of the operating reactors.

Section 2 describes information reported on the concrete and steel containments, results of inservice inspections, and regulatory actions taken to alert the licensees. Section 3 describes reported incidents of degradation of non-containment structures. Section 4 highlights the findings from staff inspections of the six older plants. Section 5 discusses the degradation of areas important to safety and various industry and regulatory activities intended as corrective measures. Section 6 gives information related to the combined industry and regulatory actions to alleviate similar future problems in the operating reactors, and makes suggestions for improving performance of structures in future reactors. The appendix gives detailed information on the inspections. 


\section{DEGRADATION OF CONTAINMENT STRUCTURES}

The containment structure (containment) is a vital engineered safety feature of a nuclear power plant. In normal operating conditions, the containment is subjected to various operating and environmental stressors, such as ambient pressure fluctuations, temperature variations, earthquakes, ice, windstorms. In some containment designs, the principal leaktight barrier is surrounded by another structure, such as shield wall or shield building, which protects the containment from such external events as rain, ice, missiles, and windstorms. The mechanical stresses and strains generated by transients under normal conditions and the effects of high-probability $\left(>10^{-2}\right)$ external influences are a small fraction of the limiting conditions for which the containment is designed. However, the fatigue life of the containment can be affected by the significant number of cycles of such low-stress transients. The containment is also subjected to various types of internal degradation (aging degradation) caused by its inherent material characteristics, fabrication processes, and construction methods. The rate and extent of such degradation are influenced by the sustained environmental conditions, such as temperature, humidity, water leakage, expulsion of chlorides, and acidic spills. Thus, performance of a containment under the design basis as well as under higher loads due to severe accident and seismic margin earthquake would be influenced by a complex interaction between its inherent ability and the various stresses and degradation mechanisms that act on it.

The 109 containments at operating nuclear units were constructed of various materials. Thirty-eight are steel containments (SCs), 31 are reinforced-concrete containments (RCCs), and 40 are PCCs.

\subsection{Reinforced and Prestressed Concrete Containments}

The following are notable instances of cracked concrete, spalled concrete, and delaminated reinforced-concrete components of containments. They were observed during construction.

- $\quad$ cracked basemats at Waterford, Three Mile Island, North Anna, and Fermi

- delaminated domes at Turkey Point and Crystal River

- cracked anchor heads (of prestressing tendons) at Byron and Bellafonte

- honeycombed and spalled concrete under equipment hatches, fuel-transfer canals, and other penetrations at several plants

NUREG/CR-4652 (NRC 1986) and Ashar, Tan, and Naus (ACI 1994) give detailed descriptions of a number of such instances and the corrective actions taken by the utilities. The following instances of significant degradation of RCCs and PCCs were reported during the operation of the plants: 
- In January 1985, anchor heads of vertical tendons at Joseph M. Farley Nuclear Power Plant were found to be cracked; three anchor heads were broken in pieces (see IE Information Notice 85-10, "Post-tensioned Containment Tendon Anchor Head Failure," Feb. 1985; Supplement 1, March 1985). Metallographic and fracture examinations showed that the failures resulted from hydrogen stress cracking of the anchor head material. The contributing factors were the high hardness of the anchor head material [American Iron and Steel Institute material 4140 with Rockwell hardness $\left(R_{c}\right)$ between 38 and 44], free water in the grease caps, and high stresses in the anchor heads. All of the cracked and broken anchor heads were replaced with newly designed ones, and the affected tendons were retensioned.

- The reactor vessel ${ }^{1}$ of Fort St. Vrain, which is not operating, is the only prestressed concrete reactor vessel in the United States. Approximately 6 percent of the prestressing tendons are equipped with load cells for continuous monitoring of prestressing forces. During an inspection in 1984, several wires in vertical, hoop, and bottom crossheads were found to be corroded, and some had failed. After an extensive investigation, the licensee determined that the most likely contributor to wire failures was microbiological corrosion (PSCC 1984)

- The base of the cylindrical wall of the containment at R. E. Ginna Nuclear Power Plant is unique in that it is supported on a series of neoprene pads, each consisting of two layers of neoprene separated and covered with three carbon steel shim plates, installed on the thickened basemat (ring beam) along the circumference of the cylinder (Figure 1). Thus, the cylinder can move in and out under the loads (temperature, internal pressure, earthquakes) by deforming the neoprene pads. The vertical posttensioning tendons are enclosed in stainless steel bellows when passing through the gap between the cylinder and the ring beam. The vertical tendons are coupled to the rock anchors at the bottom of the ring beam. An NRC staff member visiting the site noticed puddles of water near the base of the cylinder along the outside circumference of the cylinder. He noticed degradation of the asphalt coating on the wall and the insulation material placed between the pads. The licensee dewatered the area and placed effective berms to alleviate water accumulation and future degradation of the pads, tendons, and concrete. The licensee also reanalyzed the structure and confirmed through deformation measurements during leak rate testing that the containment behavior at the base (under the postulated loadings) will be within the established criteria.

- Mark I containment structures at Brunswick Steam Electric Plant (drywells and tori of the two units) are constructed of reinforced concrete with steel liner plates on the inside surfaces serving as leaktight membranes. During a routine inspection by in January 1993, the inspector found the liner plate of Unit 2 drywell to be corroded at various spots at the junction of the base floor and the liner (Figure 2). The licensee

${ }^{1}$ The corrosion at this prestressed concrete reactor vessel is a significant datapoint for pressure-resisting structures. 


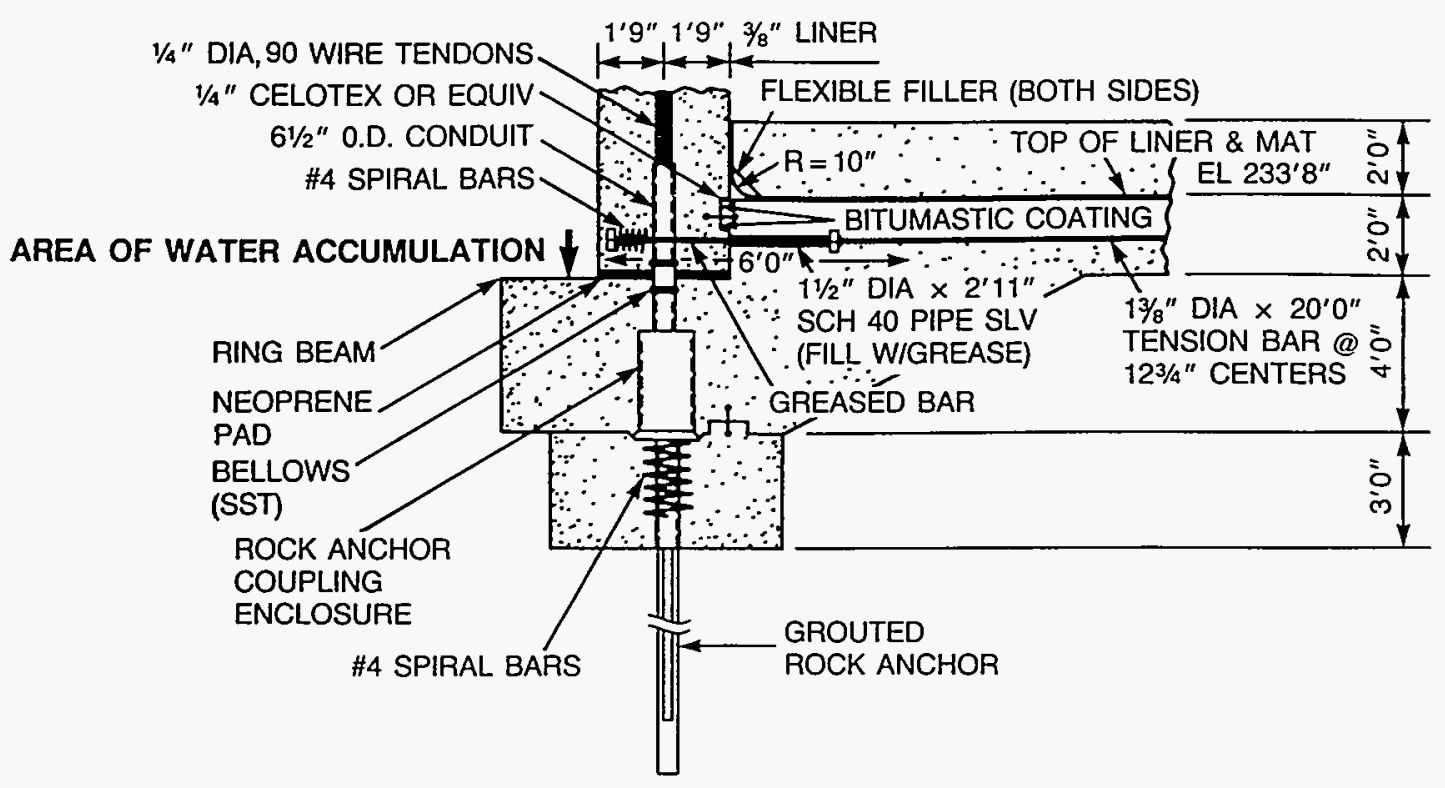

FIGURE 1 - CONTAINMENT BASE DETAILS AT GINNA

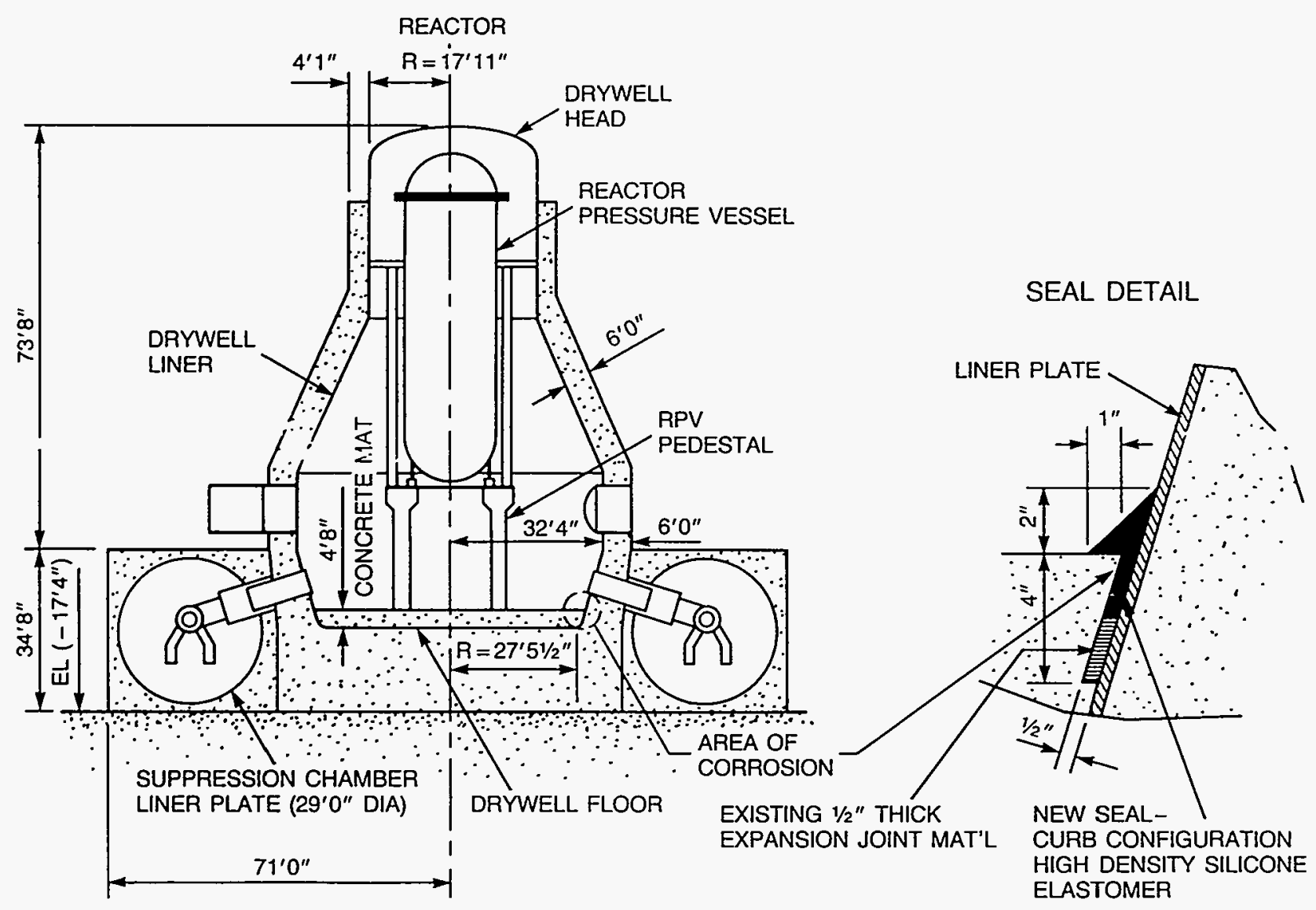

FIGURE 2 - DRYWELL LINER CORROSION AT BRUNSWICK 
later found additional corrosion areas in both the units. The sealing material along the circumference had degraded and allowed water to accumulate at the junction. Some corrosion of the liner plates in the tori had been found in earlier inspections. In the drywells, the licensee cleaned the gaps, repaired the corroded plate areas as necessary, and resealed the gaps with dense sillicon elastomer. For the corroded areas in the tori, the licensee confirmed that the noncorroded thickness of the plates is adequate for leaktightness under the postulated loading conditions, and is periodically monitoring the tori.

Several instances of higher-than-expected prestressing losses, grease leakage through concrete, and liner bulges have been observed in the PCCs of operating reactors (ACI 1994).

\subsection{Steel Containments}

NRC has received reports of incidents of steel containment corrosion. The staff discussed these incidents in the documents for its regulatory actions to alert the licensees to look for such occurrences in their plants. These incidents follow:

- $\quad$ After observing and monitoring the water leakage around various containment penetrations and floors for more than 5 years at Oyster Creek, the owner of the plant took extensive ultrasonic thickness measurements of the drywell shell to find out if the shell was being degraded. (See IN 86-99, "Degradation of Steel Containments," Dec. 1986). The measurements were taken at various locations near the sand cushion and at a higher elevation. They showed approximately $7.6 \mathrm{~mm}(0.3 \mathrm{in}$.) of the metal had been lost from the nominal metal thickness of $29.2 \mathrm{~mm}(1.15 \mathrm{in}$.) of the drywell shell in the sand-cushion areas. Measurements just above these areas in the shell indicated no reduction in the metal thickness. Figure 3 shows the area of corrosion. The licensee removed the sand from the areas affected by accumulated water and coated the drywell areas to minimize the possibility of future corrosion.

- The inside surface of the BWR Mark I containment torus shell at Nine Mile Point Nuclear Station, Unit 1, which was designed and constructed as uncoated, was evenly corroded to a thickness below the required nominal thickness in some areas of the torus. (See IN 88-82, "Torus Shells With Corrosion and Degradation of Coatings," Oct. 1988). The torus was locally pitted on the inside surface. The overall corrosion rate of the inside surface of the torus wall was estimated to be more than double the expected rate of $0.04 \mathrm{~mm} /$ year $\left(1.57 \times 10^{-3} \mathrm{in} . /\right.$ year $)$. The licensee is periodically monitoring the extent of corrosion to ensure that the remaining thickness of the torus meets the design requirements.

- The Mark I containment torus at FitzPatrick was corroded to varying degrees after the coating on the inside surface of the torus wall became severely degraded. The licensee is periodically monitoring the extent of corrosion to ensure that the remaining thickness of the torus shell in the corroded areas is adequate to meet the design requirements. 


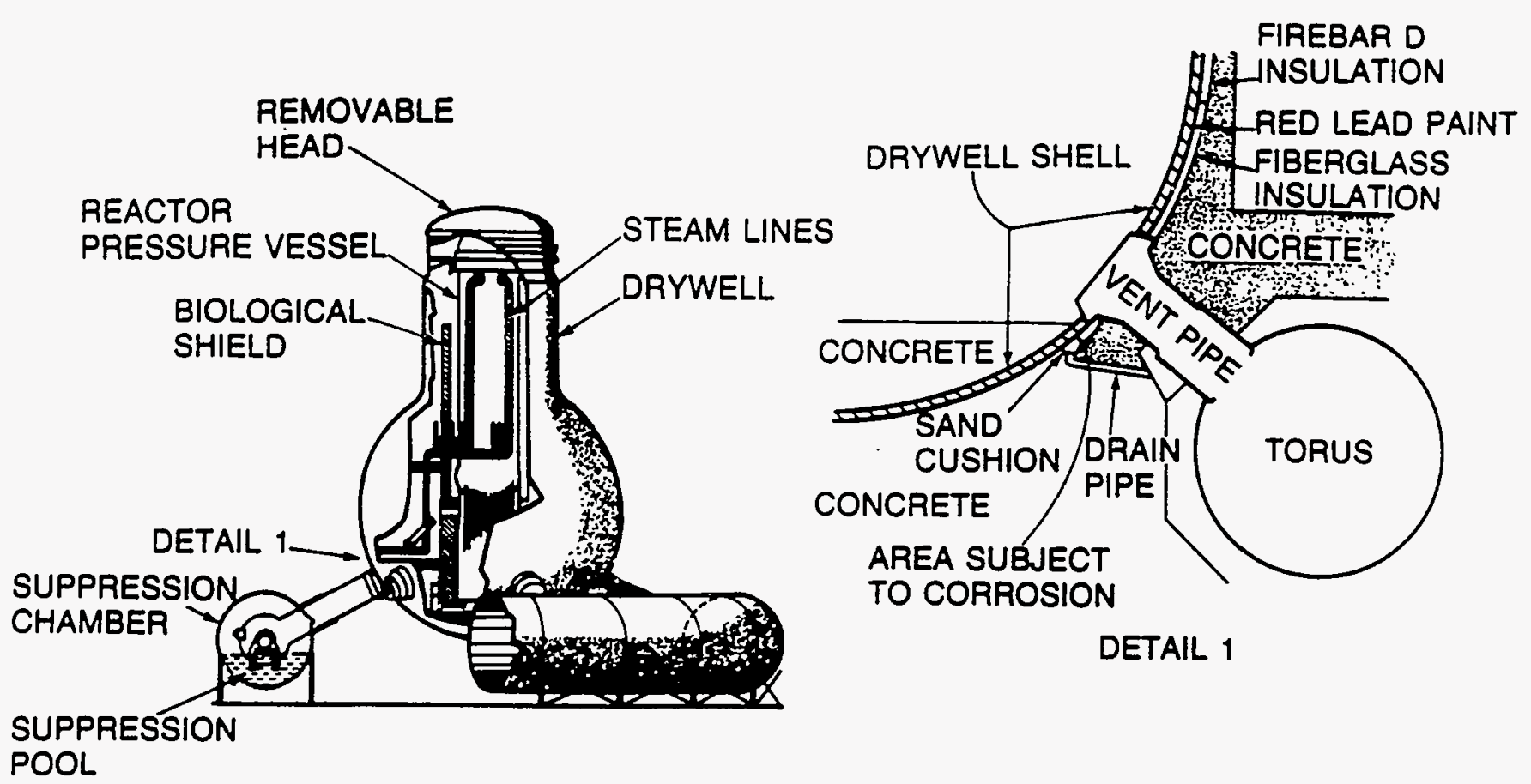

TYPICAL BWR MK 1 CONTAINMENT

\section{FIGURE 3 - DRYWELL CORROSION AT OYSTER CREEK}

- In 1989, the owner of the William B. McGuire and Catawba nuclear power plants reported significant coating damage and base metal corrosion on the outer surfaces of the steel shells of the PWR ice-condenser containments near the annulus floor levels. (See IN 89-79, "Degraded Coatings and Corrosion of Steel Containment Vessel," Dec. 1989.) The steel shells of the containments have nominal thicknesses of 25.4 $\mathrm{mm}(1 \mathrm{in}$.) near the annulus floors. The degraded areas varied in length from 5 to 10 $\mathrm{m}(16.5$ to $33 \mathrm{ft})$ along the circumferences. The average depth of corrosion was measured as $2.2 \mathrm{~mm}\left(8.7 \times 10^{-2}\right.$ in.), with pits up to $3.1 \mathrm{~mm}(0.12 \mathrm{in}$.) deep. Figure 4 shows the area of corrosion. The licensee took corrective actions to alleviate moisture accumulation and repaired the shell to ensure it was of adequate thickness.

- In 1990, the utilities reported additional instances of corrosion at higher elevations in the drywell of the Oyster Creek containment, and on the inside surfaces of the McGuire containment. (See IN 89-79, Supplement 1 "Degraded Coatings and Corrosion of Steel Containment Vessel," June 1990.) The licensees have taken actions to alleviate the possibility of future corrosion, and are periodically monitoring the affected areas. 


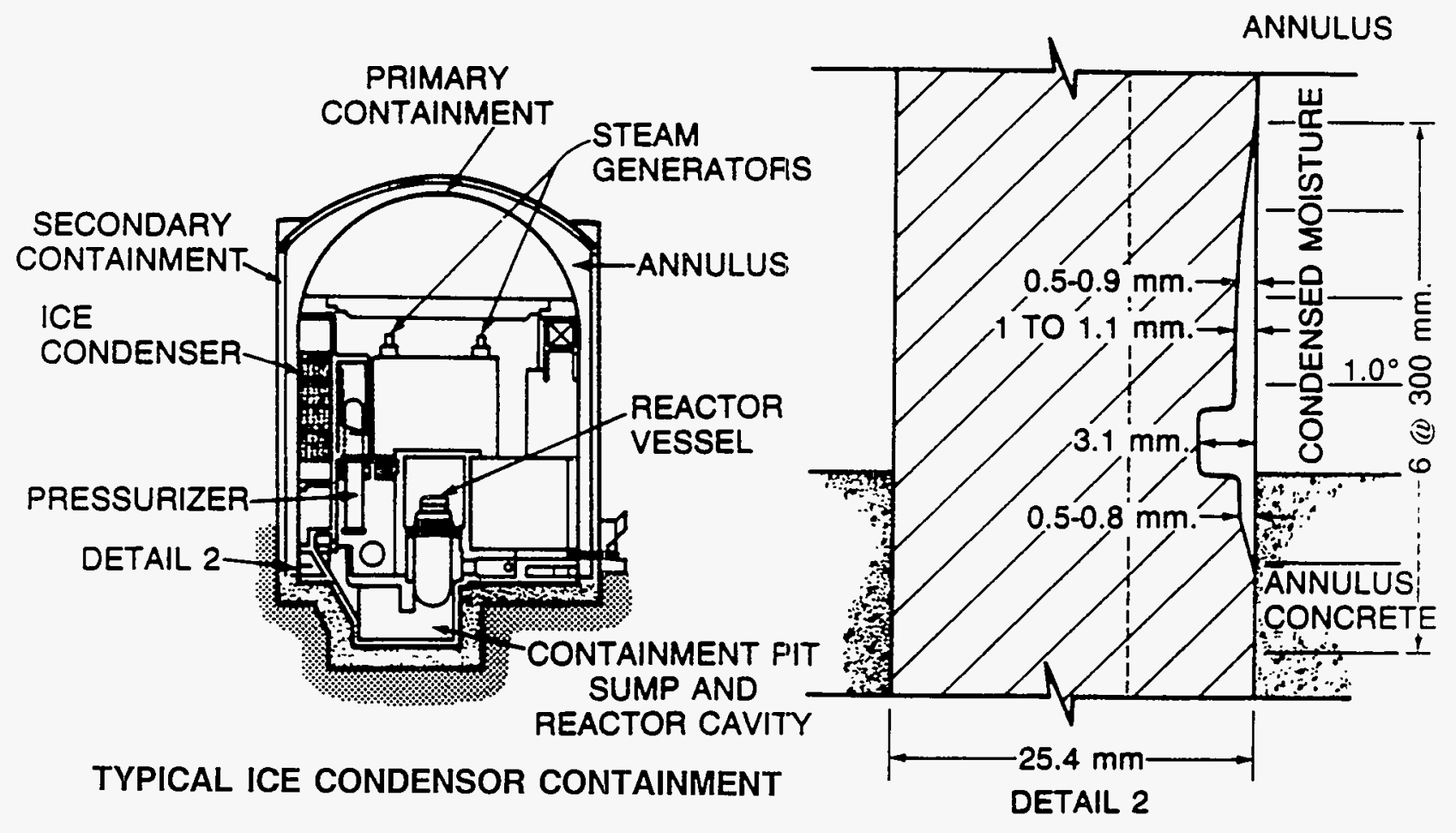

FIGURE 4 - CORROSION AT MCGUIRE 


\section{DEGRADATION OF OTHER STRUCTURES}

\subsection{Description}

The function of the other structures is to support and protect the safety-related systems and components. To satisfy these functional requirements, they are designed (1) to withstand and safely transmit the loads imposed by the supported systems and components to the foundation and (2) to safely withstand the loads imposed by the environmental events (natural and artificial). Moreover, where required, they are designed as radiation shields. Safety-related tanks are designed as reliable sources of cooling water under various environmental conditions. The other structures are primary, secondary, and biological shield walls, as well as all floors and the supporting structures in containments; reactor buildings, auxiliary (or intermediate) buildings, fuel-handling buildings, diesel generator buildings, intake structures, and service water pump-houses.

The exterior walls and roofs are constructed of reinforced concrete to protect the safetyrelated systems and components from external missiles (generated by tornados, turbine malfunctions, or aircraft) and to shield against radiation. All shield walls and buildings are constructed of reinforced concrete. The interior floors that support heavy equipment and piping are also constructed of reinforced concrete. The beams and columns that support the floors are constructed either of structural steel or reinforced concrete. Some of the interior walls in these structures are constructed of (reinforced or unreinforced) masonry blocks. The foundation mats of these structures are constructed of the reinforced concrete. The safetyrelated tanks, whether located inside structures or outside, are generally fabricated from the structural steel. Under normal plant operation, these structures (except water- or fluidretaining structures) are subjected to stresses much below their limit states. Their degradation could be attributed to sustained temperature cycles and fatigue, high humidity, and retention or spills of water or borated water. NUMARC and the Oak Ridge National Laboratory analyzed various degradation mechanisms for concrete and steel structures in nuclear power plants (NUMARC 1990, ORNL 1991).

\subsection{Experience With Structural Degradation}

NRC has issued no regulatory requirements to inspect incidents of degradation of structures in nuclear power plants or to report such incidents except as noted in Section 1.1. Thus, very little information is available in the licensee event reports or in the Nuclear Plant Reliability Data System. However, licensees have informed the NRC staff when they were considering extensive retrofitting of the structures. Moreover, in 1992, the Office of Nuclear Regulatory Research sponsored Wiss, Janney, Elstner, Inc. in.writing a survey questionnaire and distributing it to the owners of licensed nuclear power plants to obtain information on the types and location of distress in the concrete structures, the types of repairs performed, and the durability of the repairs (ORNL 1994). Twenty-nine utilities (41 reactor units) responded to the survey. The survey results pertinent to the concrete structures are summarized below: 
- Locations of Deterioration-Auxiliary building and secondary containment (shield building) walls and slabs were noted as the most common locations.

- Type of Deterioration-86 percent of the plants reported cracking, 65 percent reported spalling; over 20 percent of the respondents reported staining, honeycombing, effluorescence, and scaling.

- $\quad$ Causes of Deterioration-48 percent (of the respondents) reported deterioration resulting from drying shrinkage, 31 percent from freeze-thaw, and 24 percent from abrasion.

Krause stated that "deterioration has generally been minor due to the high initial quality of the original construction and the relatively young age of most plants" (ORNL 1994). None of the respondents reported deteriorations attributable to irradiation.

\section{Other Structures and Civil Engineering Features}

The results of the survey described in ORNL/NRC/LTR-93/28 (ORNL 1994) indicate that sodium hydroxide and sulfuric acid deteriorated the surface of structures containing neutral, acid, or caustic materials. The staff has learned about several instances of minor water leakage collected by the leakage monitoring systems from the spent fuel pools, and of leakage through cracks in stainless steel liner welds.

In one reported instance of tank deterioration, the licensee for the Haddam Neck Plant discovered a small leakage of 6 gallons per day (gpd) from the refueling water storage tank in June 1991. This cylindrical tank is 35 feet in diameter and 36 feet long, with a flat bottom and an ellipsoidal head. It is constructed of aluminum plates and structural sections and has a capacity of over 250,000 gallons. The minimum required volume of borated water is 230,000 gallons with a boron concentration of 2200 to 3000 parts per million. By September 1991, the leakage had increased to 240 gpd. After the tank was drained and decontaminated, the licensee inspected the bottom of the tank with vacuum box and soap bubble tests and found about 50 pinhole leaks. The licensee found substantial porosity in an entire length of a lap weld and determined that the tank leakage was related to weld quality. The isolated pinholes were corrected by weld overlays, and the clustered defective areas were repaired by welding plates over the defective areas.

The intake structures of the plants located in coastal areas have undergone significant degradation as described below.

- In 1987-1989, the Florida Power \& Light Co., licensee for Turkey Point, found nonconformances associated with the intake structures of Units 3 and 4 (FP\&L 1990). Extensive cracking of the reinforced-concrete beams supporting the circulating water pumps was observed. The licensee did a detailed investigation and concluded that the degradation of the beams resulted primarily from the harsh environmental conditions of Biscayne Bay where the intake structure is located and from which intake cooling 
water is supplied. The continuous exposure of the concrete to the salt water environment caused the migration of chloride ions into the concrete, corroding the reinforcing bars in the beams and causing the concrete to crack. The licensee assessed the structure of the degraded supporting beams and began corrective programs to ensure the structural integrity of the beams and minimize future penetration of chloride ions into the concrete. Although the reinforced-concrete intake structure walls were subjected to a similar environment, they did not exhibit any degradation, most likely because the reinforcing bars were protected by an adequate concrete cover [152 $\mathrm{mm}(6 \mathrm{in})$.$] .$

- During an outage inspection in 1984 at San Onofre 1, exterior concrete walls of the intake structure and concrete beams supporting service water pumps were found to have cracked extensively. The cracking occurred because chloride ions permeated the reinforcing bars, corroding the rebars. The licensee took a number of corrective actions and monitored the conditions of the walls and beams at every outage. The actions included reinforcing the walls with exterior steel plates anchored into concrete and placing sacrificial zinc anodes on the plates to protect them against corrosion. During later inspections, new areas of concrete cracking and rebar corrosion were found, but the extent of degradation was not as great. The plant has not been in operation since 1992.

- Similar incidents of rebar corrosion and concrete cracking have been reported at Pilgrim and Diablo Canyon nuclear power plants. The licensees did extensive repairs to ensure the integrity of the affected structures.

The NRC staff has observed the following types of generic degradation of other structures and civil engineering features:

- $\quad$ Equipment and piping supports inside the service water pumphouse and draft cooling towers have corroded significantly because of the sustained humid environment.

- Vent stack anchor components in unsheltered locations deteriorated because of ambient environmental exposure.

- Tendon galleries of the prestressed concrete containments degraded.

- Cracks and other deterioration of masonry-wall joints were observed.

- $\quad$ Peeled paint and minor rusting of steel structures were observed.

- Water leakage and seepage in underground structures were evident.

- $\quad$ Cast-iron buried piping was degraded.

- $\quad$ Reinforced-concrete intake tunnels were degraded. 


\section{DEGRADATION OF OTHER STRUCTURES}

- Water seepage and extensive evaporation from the ultimate heat sink ponds during droughts were evident.

- Leakage was seen through the safety-related embankments.

- Discharge canals were blocked. 


\section{INSPECTIONS OF SIX PLANTS}

Structures other than containments and the safety-related civil engineering features are not periodically inspected. Therefore, the Structural and Geosciences Branch (ESGB) prepared an inspection plan for the staff to visit six selected plants to inspect their structures. The plants were selected according to the following criteria: (1) the selected plants should be from different NRC regions, (2) the inspection activities should be coordinated with the respective regional staff and the Special Inspection Branch (RSIB) in NRR, (3) the selected plant should be from an earlier vintage (licensed before 1977) so that the age-related degradations could be observed, and (4) the containment structures of the selected plants should represent PCCs, RCCs, and SCs. Each inspection team, in general, consisted of two people from ESGB, two contractor employees (Brookhaven National Laboratory - BNL), one person from RSIB, and one person from the region. The table shows the selected plants and their significant characteristics.

\subsection{Audit-Inspection Process}

The staff and its consultant reviewed each selected licensee's commitments in the safety analysis report, the relevant licensee event reports, 10 CFR 50.59 items, and specific problem areas from the available database before each plant visit. To learn about the design basis and structural degradation problems encountered by the licensee during the operating life of the plant, the staff asked each licensee to make a presentation on the basic design, plant modifications, and procedure for maintaining the safety-related structures and civil engineering features at the plant. After the presentation and discussions of the generic items such as masonry walls, expansion anchor bolts, condition of steel water tanks, and results of containment leak rate testing and inspections, the staff did walkdown inspections of the plant structures to observe their conditions. At each plant, knowledgeable individuals from the licensee's staff accompanied the NRC staff to explain the causes of certain observations and respond to the staff's questions.

The staff maintained a log of each walkdown inspection, recording major observations, their locations, specific attributes (cracks, corrosion), photograph numbers (if taken), and comments. The staff also recorded structural components and civil engineering features in which the degradation effects might be indicated. The staff took photographs of selected items, and measured the size of cracks as appropriate to determine the severity of the degradation.

\subsection{Summary of Observations and Findings}

The appendix is a technical report prepared by the Brookhaven National Laboratory. The report contains a detailed description of the plant walkdown inspections, observations, and photographs. A summary of major problem areas found during the plant visits follows. 


\begin{tabular}{llllll}
\hline \multirow{2}{*}{ Plant } & \multirow{2}{*}{ Region } & OL Date & Containment Type & NRC & BNL \\
\hline Trojan & $\mathrm{V}$ & $05 / 76$ & PWR Dry, PCC & DJeng $^{1}$ & JBraverman \\
& & & & HAshar $^{1}$ & WGrossman \\
& & & CClark $^{2}$ &
\end{tabular}

Point

\begin{tabular}{|c|c|c|c|c|c|}
\hline Beach 1 & III & $12 / 70$ & PWR Dry, PCCs & $\begin{array}{l}\text { GBagchi }^{1} \\
\text { YKim }^{1}\end{array}$ & $\begin{array}{l}\text { JBraverman } \\
\text { RMorante }\end{array}$ \\
\hline 2 & & $10 / 72$ & PWR Dry, PCCs & $\begin{array}{l}\text { JGadzala }^{2} \\
\text { JGavula }^{2} \\
\text { HWang }^{3} \\
\text { DTang }\end{array}$ & \\
\hline
\end{tabular}

Turkey

Point 3

II $\quad 12 / 72 \quad$ PWR Dry, PCCs

RRothman ${ }^{1}$ JBraverman

HAshar ${ }^{1}$ RMorante

4

$09 / 73$

PWR Dry, PCCs

JLenahan ${ }^{2}$

Robinson 2 II

03/71

PWR Dry, RCC/PCC

GBagchi $^{1}$

JBraverman

YKim $^{1}$

RMorante

JLenahan $^{2}$

HWang $^{3}$

Beaver

\begin{tabular}{|c|c|c|c|c|c|}
\hline Valley 1 & I & $10 / 76$ & $\begin{array}{l}\text { PWR Dry, Subatm. } \\
\text { RCC }\end{array}$ & $\begin{array}{l}\text { RRothman }{ }^{1} \\
\text { JMa }^{1} \\
\text { JCarasco }^{2}\end{array}$ & $\begin{array}{l}\text { JBraverman } \\
\text { RMorante }\end{array}$ \\
\hline Cooper & IV & $07 / 74$ & BWR Mk. I, SC & $\begin{array}{l}\text { DJeng }{ }^{1} \\
\text { HAshar }^{1} \\
\text { MRunyan }^{2}\end{array}$ & $\begin{array}{l}\text { JBraverman } \\
\text { RMorante }\end{array}$ \\
\hline
\end{tabular}

${ }^{\overline{1}}$ Structural and Geosciences Branch, Office of Nuclear Reactor Regulation

${ }^{2}$ Region

${ }^{3}$ Special Inspection Branch, Office of Nuclear Reactor Regulation

4 License Renewal and Environmental Review Project Directorate, Office of Nuclear Reactor Regulation 


\subsubsection{Containment Structures}

The staff did walkdown inspections of three prestressed concrete containments, which were a good sample of the older prestressed concrete containments. Although the Trojan Nuclear Power Plant is not operating, the licensee stated that the periodic inservice inspections had repeatedly demonstrated that in spite of the grease leakages observed, the prestressing systems had performed as expected. The licensees for Turkey Point and Point Beach each stated that it had recently inspected its plant and found that although the prestressing forces of the sampled tendons were less than expected, the overall prestressing forces were acceptable. Tendon galleries of all three containments were excessively humid, and floors and walls of the galleries were damaged by sustained water infiltration. Grease had leaked through the containment concrete and was observed at Trojan and Point Beach.

Robinson 2 and Beaver Valley 1 were included in the program, not because they represented all reinforced-concrete containments, but because their condition assessment gave a general idea about the problem areas in reinforced-concrete containments. Bulging and spot corrosion of the liner plate and degradation of the liner coatings seem to be a general trend in reinforced-concrete containments as well as in prestressed concrete containments. Moreover, as expected, the surface cracking of concrete seem to be prevalent at these plants. Earlier patched concrete in both these containments seem to be deteriorating.

The inspection of the containment at Cooper gave additional data about the corrosion problems at plants with Mark I steel containments. Although the staff could not inspect the inside of the containment (drywell and torus), the licensee had identified more than 150 corrosion pits on the inside surface of the torus during previous inspections. The staff found signs of corrosion on the external surface of the torus shell, which apparently came from water that leaked from above the torus and ran down the torus shell wall, removing the red coating. This finding confirmed conclusions from the previous database that the Mark I steel containments are susceptible to corrosion.

\subsubsection{Intake Structure and Pumphouse}

The staff found degradation from water and moisture in the intake structure and pumphouse at each plant inspected. The steel and concrete components at Turkey Point were severely degraded, indicating the damaging effects of brackish water. This assessment is reinforced by the reported occurrences of corrosion and degradation at other coastal plants such as San Onofre Unit 1, Pilgrim and Diablo Canyon. The staff also found pervasive general corrosion of pump-support plates, anchor bolts, service water and circulating water pipes, and degradation of concrete surfaces at each of the five inland plants inspected.

\subsubsection{Other Safety-Related Structures}

The following observations are presented by plant rather than by structure because of the common structural features and types of degradation observed. 


\section{Trojan}

- rust buildup, corrosion, and deterioration of coatings of the containment polar crane runway rail girder, pipe supports, structural steel frame inside the containment

- concrete cracking and leaching in the bioshield wall, auxiliary building, control building, fuel building, and service water pump room

- a large vertical crack in the masonry wall in the emergency diesel room

- leakage of water from the spent fuel pool

\section{Point Beach}

- corrosion and paint blistering on service water pipes, associated valves, and cavity coolers inside the Unit 2 containment

- concrete cracking and degradation of the enclosure surrounding the large discharge pipes and general concrete cracking in the pumphouse walls, auxiliary building walls, and emergency diesel generator building

- cracking in the joints of masonry walls

- $\quad$ ground-water seepage in the underground portions of safety-related structures

- cathodic protection system relied on to prevent the corrosion of piles supporting the containment and the fuel pool basemats (The licensee tested the system and verified it functioned adequately.)

\section{Turkey Point 3 and 4}

- heavy deterioration of about $2 \mathrm{~m}^{2}\left(20 \mathrm{ft}^{2}\right)$ of the ceiling in the Unit 3 fuel handling building caused by concrete cracking and water

- cracks in the joints of unreinforced masonry walls

- very low readings (indicating lack of significant corrosion activity) in some of the anodes of the cathodic protection system installed to protect the containment liner plate, reinforcing steel, and tendon assemblies

- corrosion of the visible portion of the base plate, and bent plates on the anchor bolt chairs

\section{Robinson 2}

- corrosion of a main feedwater line support, valves, and piping of the component cooling water system inside the containment

- $\quad$ severe cracking of fill concrete covering the basemat containment liner plate

- cracking and spalling of concrete (in limited areas) in the walls and ceilings of the reactor auxiliary building, emergency diesel generator room, and intake structure. 
- corrosion of nuts at beam seats at the refueling water storage tank and primary water storage tank

- $\quad$ minor cracks in the joints of the unreinforced masonry walls

\section{Beaver Valley 1}

- long cracks in the reinforced-concrete ceilings of diesel generator rooms, primary auxiliary building, and service building

- cracks, water infiltration, and calcium deposits in the ceilings and walls of the service building, safeguard structure, and steam generator drain tank

- support deficiencies and cracks in the masonry walls of the primary auxiliary building, service building, and cable vault structure

- degradation of the foundation and corrosion of steel supports in the switchgear room

- corrosion of steel supports under the fan coil unit, the main steamline, and the feedwater piping in the cable vault structure

- corrosion of structural steel items in the safeguard structure

\section{Cooper}

- cracking and spalling of concrete in the service water booster pump room and in the exterior walls of the diesel generator building and reactor building.

- $\quad$ severe corrosion and degradation of piping supports, anchorages, and tanks in the control building. These components are associated with the residual heat removal service water booster pump.

- corrosion of pipes and supports and other steel items in lower levels of the control building and reactor building and at the base of the release tower

- deficiencies in anchorages, such as missing bolts and nuts, gaps between the anchor head and the base plates, insufficient thread engagement of anchor nuts, and missing anchors

\subsubsection{Civil Engineering Features}

Buried Piping and Pipe Tunnels. Almost every plant has buried certain safety-related piping such as the service water and the diesel fuel lines. Piping carrying the primary water from a storage tank to the pumps may be partially buried. The licensees for three of the six plants visited stated that they had found degradation on the internal coating and the base metal (carbon-steel or cast-iron) of buried piping. At two plants, long lengths of large-size pipe-tunnels are used to bring service water from a lake and a river. Submerged in water, they are accessible for inspections only by divers. However, the licensees stated that they inspected pipe-tunnels when they found signs that normal water flow was obstructed by accumulated salt, sand, and debris. 
Safety-Related Dams and Cooling Canals. The H. B. Robinson plant has a safety-related dam which had shown appreciable leakages from the spillway gates, concrete cracking, and corrosion of spillway bridge beam seats. The licensee planned to make necessary repairs. The dam is inspected by the licensee in accordance with Regulatory Guide 1.127. The Turkey Point plant has an extensive network of conling canals in which the flow is affected by silting and clogging. The licensee stated that it frequently dredged the canals to ensure efficient flow of water.

Settlement Monitoring and Seismic Gaps. The plant sites where the soil conditions warranted monitoring of the ground (foundation) settlement had settlement monitoring plans. The settlement monitoring at Point Beach and Beaver Valley indicated ground settlements under structures. However, the licensees stated that the settlement readings were within the design limits of structures. Before NRC issued the operating license for Beaver Valley, the outfall structure at the plant experienced appreciable differential settlement. The structure was underpinned with piles.

The licensees of all the plants visited stated that the plant designs required seismic gaps of between $5 \mathrm{~cm}$ ( 2 in.) and $10 \mathrm{~cm}(4 \mathrm{in}$.$) . None of the licensees monitored the gaps after$ construction. The staff observed quite a variation in the actual seismic gaps at accessible visible areas. In some cases, the expansion fillers had been worn out due to the partial closure of the gaps. In other cases, the expansion fillers and. debris had settled down due to the enlargement of the gaps. It could not be determined whether these observations were due to the differential settlement (i.e., tilting) of the structures or whether they reflected the original configurations during the construction with minor adjustments resulting from the operating loads and aging of the materials.

Ground-Water Effects. Portions of the safety-related structures at all the plants are located below the normal ground-water level at the sites. All these structures are constructed with some type of waterproofing provisions on the exterior portions of the below-grade structures. Water infiltration and water-related degradation had been noticed at all the plants. At Trojan, Turkey Point, Point Beach, and Cooper, the water infiltration in the below-grade structures resulted more from the improper drainage of the surface water rather than from the ground-water infiltration.

Seismic Instrumentation. Each plant had a seismic instrumentation program (seismic event detection and maintenance). Turkey Point has only one seismograph in Unit 3. However, additional field recorders are planned in coordination with the State of Florida and U.S. Geologic Survey (USGS) network to determine seismic attenuation factors in the Southeast United States. Point Beach has four seismic event indicators (digital cassette accelerographs): one in the free field and the other three at lower elevations in the safetyrelated structures. The licensees were not planning to upgrade the programs to address the guidelines in EPRI NP-5930 (1988). 


\section{FINDINGS}

Recognizing a need to monitor the effectiveness of maintenance activities for safety related SSCs, the Commission issued a final "maintenance rule" in 10 CFR 50.65, in July 1991. The main objective of the "maintenance rule" is to monitor the overall continuing effectiveness of maintenance programs used by the licensees of the operating reactors to ensure that safetyrelated (and certain non-safety-related) SSCs are capable of performing their intended functions. The rule requires the licensees of operating reactors to establish performance (or condition) goals for the SSCs and to monitor their performance (condition) against the established goals. Though the rule is performance based, and not prescriptive, it gives adequate guidance for licensees to establish effective maintenance programs without duplicating efforts. The rule is applicable to the monitoring of effectiveness of the licenseeestablished maintenance program for the structures.

A properly established inspection and maintenance program will be beneficial to the plant owners in ensuring the integrity of the plant structures. For the types of materials (normalweight, medium-strength concrete and mild steel) used in the building structures of the nuclear power plants, it is evident that "concrete cracks and steel corrodes." To minimize the consequences of this degradation, codes of practice and specifications require minimum reinforcing to control cracks, even when the design indicates low or no reinforcing. The codes and specifications emphasize quality control at each stage of concrete construction, controlled fabrication processes, and painting of steel structures. These measures alone do not ensure long-term durability of the structures, particularly when the structures are subjected to sustained adverse environmental conditions. For example, the life of a structure can be reduced by the corrosion of reinforcing bars in the intake structures caused by the high chloride content of brackish water. The life of a structure can also be reduced when high moisture and humidity cause corrosion of the drywell and torus of a Mark I containment.

The importance of periodic inspections of the structures, as a part of the systematic maintenance program, cannot be over emphasized. Substantial safety and economic benefit can be derived if the scope of inspections is comprehensive and includes degradation sites of difficult access that may not otherwise be inspected. Timely repair or remedial action to arrest continuing or benign degradations will ensure continued safety of the structures, particularly in the areas of difficult access.

\subsection{Containment Structures}

The inside surfaces of the torus of the Mark I containment structure at Cooper Nuclear Station are coated with Carbo Zinc II, a coating material that was qualified to withstand the pressures and temperatures of the steam environment of design-basis accidents. Coating degradation and base metal pitting were most severe near the bottom of the torus. This observation indicates that the coated steel surfaces require periodic inspections even in the oxygen-deficient areas. A systematic maintenance program is needed for other steel containments and for the steel liners of the concrete containments. 


\section{FINDINGS}

Prestressing forces in PCCs are periodically monitored by monitoring programs generally following the provisions in Regulatory Guide 1.35 . While visually examining PCCs before doing integrated leak rate testing, the licensee can easily find any gross degradation of the accessible surfaces of the steel, reinforced-concrete, or prestressed concrete containment. However, experience indicates that without detailed and comprehensive inspection provisions, the conditions of these structures in the operating reactors cannot be assessed with confidence.

\subsection{Intake and Pumphouse Structures}

The nuclear industry is aware that debris, biofouling, and icing can restrict flow at intake and pumphouse structures. The NRC staff has issued generic communications such as Generic Letter 89-13 and IE Bulletin 81-03 to ensure proper operation of the service water systems at nuclear power plants. These actions do not incorporate any guidance or recommendations for periodic inspections and maintenance of intake and pumphouse structures. However, during the plant visits, the visiting teams observed that the licensees were, in general, conducting surveillances and repairs to ensure the continued functioning of the structures.

\subsection{Other Prestressed Concrete Structures}

Although prestressed concrete containment structures are monitored by periodic inspections, licensees do not consistently maintain other structures (or structural components) of prestressed concrete construction such as spent fuel pool girders, ice-condenser floor systems, and reactor cavity walls. The prestressing tendons in these structures are protected from corrosion by corrosion-inhibiting grease or by Portland Cement grout. Although NRC has no regulatory provisions to periodically monitor these structures and their prestessing systems, economics alone would dictate that they should be monitored to prevent any unexpected or early loss of prestressing force or corrosion degradation of prestressing components.

\subsection{Masonry Walls}

Safety-related masonry walls (reinforced and unreinforced) have little seismic resistance, and most are not part of the primary load-transferring structures in nuclear power plants. These walls are either partition walls between equipment areas or supports for raceways and smalldiameter piping. Their failure under a postulated seismic event could affect the functioning of the safety-related equipment or jeopardize the functioning of the supported components. In IE Bulletin 80-11, the staff gave criteria for ensuring the seismic adequacy of masonry walls. Section 5.3.1 of NUMARC (now NEI) Report 90-06 states that cracks in the masonry wall joints are likely to appear at all plants (NUMARC 1990). During the plant visits, the inspection team observed cracks in the masonry walls of all plants. The staff issued Information Notice 87-67 to alert licensees to deficiencies in masonry walls and has received reports that the steel supporting systems designed to give lateral support to the unreinforced masonry walls in several plants are not properly anchored. 


\subsection{Buried Piping}

The staff found degradation of internal coatings of buried piping at three of the six plants visited. Licensees took remedial action after the degradation resulted in inadequate flow conditions or unacceptable water quality. The degraded buried piping could pose difficulties in the transfer of adequate cooling water, particularly if the piping suffers differential settlement during a seismic event.

\subsection{Settlement of Structures and Seismic Gaps}

Seismic gaps between adjoining buildings at the plants visited are not in accordance with design. Some variation in gap sizes is expected as a result of construction tolerances and temperature-related movements of the buildings. If differential settlement of one or both of the building structures caused changes in the gaps, the distress from the settlements should be apparent at the structural hard spots, such as large piping penetrations and large doorways. Observing and assessing the effects of settlement of the structures should be a part of the inspection and maintenance program for all structures - safety-related structures and nonsafety-related structures that could affect safety-related structures, systems, and components. Maintaining a minimum seismic gap (as required by the calculated drift of the structures under the safe shutdown earthquake) is important to prevent damage to the affected structures, or failure of the affected equipment and component (e.g., critical relays) from being a dominant contributor to seismic risk. (EPRI 1991)

\subsection{Safety-Related Water Storage Tanks}

During the plant walkdown inspections, the inspection teams observed missing nuts, corroded chairs, bent support plates. Implementation of the resolution of unresolved safety issues A40 through USI A-46 and individual plant examination of externally initiated events (IPEEE) programs require thorough walkdown inspections and evaluations of the safety-related storage tanks.

\subsection{Piping and Equipment Anchorage Deficiencies}

During the walkdown inspections of the six plants, the staff observed separation of grout beneath the equipment base plates, corroded anchor bolt nuts, and corroded plates. Serious degradations were found in the intake structures and service water pumphouse structures. Subsection IWF of Section XI of the American Society of Mechanical Engineers (ASME) Code (ASME 1992b) contains requirements for inspecting the pipe and equipment supports. This industry standard should be useful to plant owners in maintaining these components.

\subsection{Inaccessible Structures}

Parts of various structures and civil engineering features at nuclear power plant sites are not accessible for periodic inspections. Degradations in inaccessible structures or parts of structures are uncovered usually when difficulties in operation are encountered, such as those 
involving intake structures at Turkey Point and San Onofre Unit 1. Thus, areas inaccessible for periodic inspections, such as underground or underwater portions of the structures, need to be realistically evaluated for susceptibility to degradation mechanisms and sustained as well as infrequent stressors. These evaluations should include consideration of site-specific (plant-specific) characteristics, experience at other nuclear power plants, and the history or testing of such features (e.g., piles) under similar conditions. Where feasible, these features should be closely inspected at an appropriate interval (e.g., 10 years) using divers or ground exploration. A similar inspection philosophy can be used for areas of high radiation, such as around the reactor, inside containment, and inside BWR suppression pools. The periodic inspection (evaluation) of inaccessible areas should be considered for incorporation in all requirement and guideline documents for the maintenance of structures at nuclear power plants.

\subsection{Evaluations Under 10 CFR 50.59}

The staff reviewed the methods used by the six licensees to document changes, modifications, or additions that they might have been performed under 10 CFR 50.59 for structures or components. The regulation gives the licensees latitude in performing changes, modifications, or additions on the safety-related structures, systems, and components without acquiring prior approval from the Commission. However, the licensees have to determine that such operations would not reduce the existing safety margins, or generate unreviewed conditions which would affect safety. Even when a specific operation (change, modification, or addition) has been found acceptable under this regulation, the regulation requires that the evaluation of safety impact of the operations be properly documented, and the documentation be made available to the Commission staff when requested. The staff reviewed such documentation on the structures and civil engineering features during the plant visits and found that the evaluations done before 1989 were not as comprehensive as the ones performed since the publication of NSAC-125 guidelines in May 1989 (EPRI 1989). The quality of evaluations was found to have improved significantly. Though the NRC has not endorsed the guidelines and the licensees have not adopted them in their procedures to evaluate 10 CFR 50.59 items, the effect of the guidelines was visible in a few recent evaluations that the staff reviewed. 


\section{OBSERVATIONS AND CONCLUSIONS}

In Chapter 9 of the appendix, the BNL staff describes a degradation rating system based on the severity of the degradations observed during the staff visits to the six selected plants. It also makes several observations for repair and maintenance of such degradations. The rating system developed by the BNL staff could be useful in developing graded maintenance programs. However, the recommendations made in the chapter regarding the actions to be taken by the NRC staff are not endorsed by the NRC staff. The following information incorporates the results of the BNL's findings together with the other available information and ongoing industry and NRC activities.

\subsection{Operating Reactors}

The following information for monitoring and maintaining the structures in nuclear power plants should be helpful to the licensees of operating reactors in establishing suitable performance goals commensurate with the safety functions of the structures:

(1) Subsections IWE and IWL of Section XI of the ASME Boiler and Pressure Vessel Code contain rules for inspecting the steel and concrete containments and criteria for evaluating, repairing, and replacing the degraded areas (ASME 1992a,c). NRC is in the process of amending 10 CFR 50.55a to endorse these subsections. The licensees will significantly enhance the safety of containments in the nuclear power plants by implementing the amended rule.

(2) Committee 349 of the American Concrete Institute (ACI) is in the process of publishing a guideline document for the proper inspection, evaluation, repair, and maintenance of the concrete structures in nuclear power plants including intake structures, pump houses, and prestressed concrete structures (ACI 1993). The documentation (when finally published) will be useful to the licensee in developing inspection program for safety- related concrete structures.

(3) As discussed in section 5.4, safety-related masonry walls and their steel supporting structures need attention to ensure their safety functions. The actions implemented by the plant owners to conform to the existing provisions (i.e., IE Bulletin 80-11) and repairing the cracks will help maintain the intended functioning of the masonry walls.

(4) The settlement and seismic gap of structures are more relevant to overall risk studies than to the operating behavior of the structures. EPRI has discussed the importance of this issue in Appendix A to EPRI NP-6041-SL, Revision 1 (EPRI 1991). The issue is being addressed for focused scope and full scope seismic evaluations during the implementation of Supplement 4 to GL 88-20. Evaluation of the adequency of seismic gaps between the structure should be performed during the implementation of GL 8820.

(5) Proper implementation of the resolution of USI A-40 and USI A-46 program related to the safety-related tanks followed by an appropriate periodic inspection program 


\section{OBSERVATIONS AND CONCLUSIONS}

commensurate with the safety functions of the tanks will assure the safety performance of the safety-related water storage tanks.

(6) Paragraph (g)(4) of 10 CFR 50.55a requires inservice inspections of Class 1, 2, and 3 components and their supports in accordance with ASME Section XI. The staff observed degradation of support anchorages in various Class 2 and 3 piping, and that of buried piping. The staff had issued two generic communications to alert the licensees regarding such degradations. Generic Letter 91-18 gives information on resolving degraded and nonconforming conditions affecting all safety-related SSCs. The staff issued adequate guidance in Information Notice 95-09 for the maintenance of Class 1, 2, and 3 piping and its structural supports.

\subsection{Future Reactors}

The following information for improvements in the design and construction of structures of the future reactors is based on the experience with the performance of the structures in the operating reactors. An appropriate use of this information will enhance the service performance of these structures.

(1) The recommendations made by Ashar, Tan, and Naus (ACI 1994) for alleviating the types of problems encountered in prestressed concrete containments of the operating reactors could be useful for better designs of future PCCs.

(2) Most of the degradations of the steel shell and steel liners of reinforced and prestressed concrete containments are associated with the presence of high humidity or water, even in the oxygen-deficient areas. Improved coatings, liberal corrosion allowance, state-of-the-art methods for remotely monitoring corrosion, and use of impressed current corrosion protection system for sites susceptible to degradation would help alleviate the problems encountered in the operating reactors.

(3) Use of low-permeability concrete, epoxy-coated reinforcing bars, stainless steel liners, proven coating systems, and state-of-the-art methods for monitoring the corrosion of reinforcing bars in concrete structures, particularly in areas difficult to inspect, such as water-intake, and pumphouse structures (which are likely to be exposed to brackish or corrosive fluids) are suggested means of alleviating such problems.

(4) Proper drainage of the expected surface water at the site, and use of reliable waterproofing and water-stops for underground portions of the structures to alleviate the types of degradation found in the underground portions of the structures in the operating reactors.

(5) Avoiding the use of masonry walls as safety-related structures, and non-ductile expansion anchor bolts would alleviate the types of problems encountered with their use in the operating reactors.

(6) Installation of remote corrosion protection and corrosion monitoring systems in buried piping and steel piles will be helpful in monitoring these difficult to access structres. 


\subsection{Conclusions}

Although quality of construction is the primary factor in ensuring the durability of nuclear structures, it is not a substitute for periodic inspections and maintenance of the structures and civil engineering features. The observations and information related to these structures support the fact that such construction should be followed by periodic inspections and a systematic maintenance program to ensure the expected useful life of the structures. This principle underlies NRC's maintenance rule, 10 CFR 50.65. 



\section{REFERENCES}

ACI 1993

American Concrete Institute, "Evaluation of Existing Nuclear SafetyRelated Concrete Structures," ACI 349 3R-94 (Draft). Detroit, Michigan, 1993.

ACI 1994 H. Ashar, C.P. Tan, and D. Naus. "Prestressing in Nuclear Power Plants." Concrete International. Detroit, Michigan: American Concrete Institute, May/June 1994.

ASME 1992a American Society of Mechanical Engineers. Boiler and Pressure Vessel Code, Section XI, Subsection IWE, "Inservice Inspection Requirements for Class MC and Metallic Liners of Class CC Components of LightWater Cooled Reactors." New York, New York, 1992.

ASME 1992b American Society of Mechanical Engineers. Boiler and Pressure Vessel Code, Section XI, Subsection IWF, "Inservice Inspection Requirements for Class 1, 2, 3, and MC Component Supports of Light-Water Cooled Reactors." New York, New York, 1992.

ASME 1992c American Society of Mechanical Engineers. Boiler and Pressure Vessel Code, Section XI, Subsection IWL, "Inservice Inspection Requirements for Class CC Concrete Components of Light-Water Cooled Reactors." New York, New York, 1992.

EPRI 1988 Electric Power Research Institute. "A Criterion for Determining Exceedance of the OBE," EPRI NP-5930. Palo Alto, California, July 1988.

EPRI 1989 Electric Power Reaserch Institute, Nuclear Safety Analysis Center. "Guidelines for 10 CFR 50.59 Safety Evaluations," NSAC-125. Palo Alto, California, May 1989.

EPRI $1991 \quad$ Electric Power Research Institute. "A Methodology of Assesșment of Nuclear Power Plant Seismic Margin," EPRI NP-6041-SL, Rev. 1. Palo Alto, California, August 1991.

FP\&L $1990 \quad$ Florida Power and Light Company. "Structural Assessment of Units 3 and 4 Intake Structures," JPN-PTN-SECS-90-094. NRC Dockets 50-250 and 50-251. September 1990.

NRC 1986 U.S. Nuclear Regulatory Commission. "Concrete Component Aging and Its Significance Relative to Life Extension of Nuclear Power Plants," NUREG/CR-4652. Oak Ridge Tennessee: Oak Ridge National Laboratory, September 1986. 
NUMARC 1990 Nuclear Management and Resources Council, Inc. "Class Structures, License Renewal Report," Technical Report 90-06. Washington, D.C.: Nuclear Energy Institute, June 1990.

ORNL 1991 C. Hookam. "Structural Aging Assessment Methodology for Concrete Structures in Nuclear Power Plants," ORNL/NRC/LTR-90/17. Oak Ridge, Tennessee: Oak Ridge National Laboratory, March 1991.

ORNL 1994 P. Krause. "Repair Materials and Techniques for Concrete Structures in Nuclear Power Plants, " ORNL/NRC/LTR-93/28. Oak Ridge, Tennessee: Oak Ridge National Laboratory, March 1994.

PSCC 1984 Public Service Company of Colorado. "Examination of Failed Tendon Wires From Fort St. Vrain," Lab Report 52. NRC-PDR Docket 50-267. Denver, Colorado, December 1984. 
APPENDIX A

ASSESSMENT OF AGING

DEGRADATION OF CIVIL/STRUCTURAL FEATURES

AT SELECTED OPERATING NUCLEAR POWER PLANTS

\section{by}

J. Braverman

R. Morante

C. Hofmayer

Brookhaven National Iaboratory

Engineering Research and Applications Division Upton, NY 11973

May 1993 

CONTENTS

Page

1 OBJECTIVE AND SCOPE . . . . . . . . . . . . . . . A-1

2 AUDIT PROCESS . . . . . . . . . . . . . . . A-3

3 TROJAN NUCLEAR POWER PLANT . . . . . . . . . . . . A-5

4 POINT BEACH NUCLEAR PLANT - UNITS 1 \& 2 . . . . . . . A-15

5 TURKEY POINT NUCLEAR POWER PLANT - UNITS 3 \& 4 . . . . A-25

6 H.B. ROBINSON NUCLEAR PLANT - UNIT 2 . • • • • • . . . A-35

7 BEAVER VALLEY POWER STATION - UNIT 1 . . . . . . . . A-47

8 COOPER NUCLEAR STATION . . . . . . . . . . . . A-59

9 CONCLUSIONS AND RECOMMENDATIONS . . . . . . . . . . A-69

\section{PIATES}

1. Trojan Nuclear Power Plant - Grease Leakage

From Tendon Casings . . . . . . . . . . . . . . . . A-9

2. Trojan Nuclear Power Plant - Tendon Gallery -

3. Trojan Nuclear Power Plant - Tendon Gallery -

4. Trojan Nuclear Power Plant - Turbine Building and Intake structure - Concrete Degradation, Water

Infiltration, and concrete cracking . . . . . . . A-12

5. Trojan Nuclear Power Plant - Control Building -

6. Point Beach Nuclear Plant - Unit 1 containment, Buttress D Horizontal Tendon Anchors - Concrete Damage and Grease Leakage . . . . . . . . . . . A-20

7. Point Beach Nuclear Plant - Unit 2 containment Miscellaneous Observations . . . . . . . . . . . A-21

8. Point Beach Nuclear Plant - Unit 2 Tendon Gallery -

9. Point Beach Nuclear Plant - North Service Water

10. Point Beach Nuclear Plant - Central Auxiliary • • • A-23 Building - Evidence of Water Seepage . . . . . . . A-24

11. Turkey Point Nuclear Power Plant - Unit 3 Tendon Gallery - Grease Leakage, Metal Corrosion, and Concrete Cracking . . . . . . . . . . . . . . A-30

12. Turkey Point Nuclear Power Plant - Unit 3 Containment Dome - Peeling of Dome Coating Material - A-31 
Page

13. Turkey Point Nuclear Powr Plant - Intake Structure . . A-32

14. Turkey Point Nuclear Power Plant - Unit 3 Spent Fuel Building and Air Handling Room in Control Building Area of Discoloration and Gap Between Masonry Wall and Angle Support . . . . . . . . . . . . . . A-33

15. Turkey Point Nuclear Power Plant - Unit 3 condensate Storage Tank - Deterioriation/Corrosion . . . . . . A-34

16. H.B. Robinson Nuclear Plant, Unit 2 - Inside Containment - Corrosion .. . . . . . . . . . A-40

17. H.B. Robinson Nuclear Plant, Unit 2 - Inside Containment - Peeling and cracking of coating on Basemat . A-41

18. H.B. Robinson Nuclear Plant, Unit 2 - Reactor Auxiliary Building - Membrane Tear and water Infiltration . . . . . . . . . . . . . . . . . . A-42

19. H.B. Robinson Nuclear Plant, Unit 2 - Intake Structure - Corrosion, Degradation, and Cracking . . A-43

20. H.B. Robinson Nuclear Plant, Unit 2 - Intake Structure - severe Pitting of Service Water Line, Below Grade . . . . . . . . . . . . . . . $\mathrm{A}-44$

21. H.B. Robinson Nuclear Plant, Unit 2 - Seismic Class 1 Area of Turbine Building and Beam seat of Primary Water Storage Tank -Corrosion . . . . . . . A-45

22. Beaver Valley Power Station, Unit 1 - outside Containment Wall - Concrete Crack Pattern . . . . . A-51

23. Beaver Valley Power Station, Unit 1 - Containment and Safeguards structure - Corrosion and Water Infiltration . . . . . . . . . . . . . . . A-52

24. Beaver Valley Power Station, Unit 1 - Intake Structure - Cracking, Degradation, and Corrosion . . A-53

25. Beaver Valley Power Station, Unit 1 - South wall of Diesel Generator Building and steam Generator Drain Tank - Concrete Spall, Corrosion, Cracking, and Water Infiltration . . . . . . . . . . . . . . A-54

26. Beaver Valley Power Station, Unit 1 - Primary Auxiliary Building - Cracking, Discoloration, and Degradation . . . . . . . . . . . . . . . . A-55

27. Beaver Valley Power Station, Unit 1 - Safeguards Structure and Service Building - Corrosion and Water Infiltration . . . . . . . . . . . . . . A-56

28. Beaver Valley Power Station, Unit 1 - Service Building, Control Room Condenser Unit - Degradation and Corrosion . . . . . . . . . . . . . . A-57

29. Cooper Nuclear station - Reactor Building Torus and Exterior Concrete Wall - Corrosion and Water Infiltration... . . . . . . . . . . . . . . A-63

30. Cooper Nuclear station - Intake structure, Service Water Pump Room - Degradation . . . . . . . . . A-64

31. Cooper Nuclear Station - Intake Structure -
Corrosion in Service water Pump Room - Corrosion . . . A-65 
Page

32. Cooper Nuclear station - Control Building, Service Water Gland Water System - Corrosion/Degradation . . . A-66

33. Cooper Nuclear station - Control Building, RHR Service Water Booster Pump - Corrosion . . . . . . . A-67

34. Cooper Nuclear station - Reactor Building and Elevated Release Point Tower - Cracks, Spalling, and Corrosion . . . . . . . . . . . . . . A-68 


\section{OBJECTIVE AND SCOPE}

\section{OBJECTIVE}

The objective of this evaluation effort was to obtain information about the performance of structures at operating plants and to draw some generic conclusions based on the information obtained from the plant visits. To achieve this objective, an assessment of the existing condition and past performance of structures and civil engineering features at six plants was performed. Any failures, degradations, maintenance activities, surveillance programs, modifications/repairs of safety-related structures were of interest.

SCOPE

To achieve the objective described above, six representative older vintage plants were selected by the NRC. These plants were selected on the basis that they are older vintage (generally pre1975) plants, are non SEP plants, are geographically diverse (from different NRC regions), have different containment designs, and have unique design features.

The six plants are listed below along with the date of commercial operation, NRC region, type of containment, and the date at which the audits/walkdowns were conducted.

\begin{tabular}{||l|c|c|c|c||}
\hline $\begin{array}{l}\text { Plant } \\
\text { Name }\end{array}$ & $\begin{array}{c}\text { Commercial } \\
\text { Operation }\end{array}$ & $\begin{array}{c}\text { NRC } \\
\text { Region }\end{array}$ & $\begin{array}{c}\text { Containment } \\
\text { Design }\end{array}$ & Plant Visit \\
\hline Trojan & $5 / 76$ & V & $\begin{array}{c}\text { Prestressed } \\
\text { Concrete }\end{array}$ & $7 / 22-25 / 91$ \\
\hline $\begin{array}{l}\text { Point } \\
\text { Beach } \\
\text { \& } 2\end{array}$ & $\begin{array}{l}12 / 70 \\
10 / 72\end{array}$ & III & $\begin{array}{l}\text { Prestressed } \\
\text { Concrete }\end{array}$ & $10 / 21-24 / 91$ \\
\hline $\begin{array}{l}\text { Turkey } \\
\text { Point } \\
3 \text { \& 4 }\end{array}$ & $\begin{array}{c}12 / 72 \\
9 / 73\end{array}$ & II & $\begin{array}{l}\text { Prestressed } \\
\text { Concrete }\end{array}$ & $1 / 13-17 / 92$ \\
\hline $\begin{array}{l}\text { H.B. } \\
\text { Robinson } \\
2\end{array}$ & $3 / 71$ & II & $\begin{array}{l}\text { Prestressed } \\
\text { Concrete }\end{array}$ & $4 / 13-16 / 92$ \\
\hline $\begin{array}{l}\text { Beaver } \\
\text { Valley 1 }\end{array}$ & $10 / 76$ & I & $\begin{array}{l}\text { Reinforced } \\
\text { Concrete }\end{array}$ & $6 / 15-19 / 92$ \\
\hline Cooper & $7 / 74$ & IV & steel & $8 / 17-21 / 92$ \\
\hline \hline
\end{tabular}


The type of structures and civil engineering features that were included in the scope of review were seismic category I buildings; tanks; cable tray, conduit, and HVAC supports; underground structures; water intake structures; and anchorages. The Seismic Category I buildings reviewed include reactor building, containment, radwaste building, control building, fuel handling building, water intake structure, diesel generator building, safety-related areas of the turbine building, and release stacks. Both the interior and exterior portions of building structures were examined. Structural components reviewed include the reinforcedconcrete and structural steel - floors, walls, ceilings, and roofs; masonry walls; and fuel racks. 


\section{AUDIT PROCESS}

To gain an understanding of the scope of Seismic Category I structures and the type of loads the structures are required to survive at each specific site, the Licensee was requested to make a formal presentation prior to the walkdowns. The presentations provided a brief description of the seismic design criteria, design codes/standards, and what provisions have been made to design or protect safety-related plant structures from the effects of various loads such as wind, tornado, flood or dam failure.

The presentation also served to inform the audit team about degradations identified by the Iicensee. Thus, the presentations generally covered topics which include containment testing and surveillance results and plant experience with settlement of structures, ground water or surface water infiltration, cracking of concrete structures, corrosion of steel, problems with anchorages, cracks in masonry walls, problems with equipment foundations (e.g., tanks) and maintenance/operability of seismic instrumentation. Also reviewed were civil/structural Licensing Event Reports (LERs), 10 CFR 50.59 evaluations, and past dispositions of structural issues identified in previous NRC staff inspection reports.

Following the presentation and discussion with the Licensee about their observations and experience with the performance of structures with respect to degradation, walkdowns were conducted. The audit team consisted of two representatives from $B N L$, and several representatives from the NRC. The Licensee also provided personnel who were assigned to guide us throughout the plant and to answer questions raised by the audit team. If questions could not be immediately answered, they were recorded for follow-up by the plant staff.

During all the walkdowns a log was maintained in which the team recorded for each observation the building/area, elevation, location, component/item, aspect reviewed, photograph number, and any comments. Data were recorded for structural components where aging degradation effects were present as well as where they were not. Photographs were taken for selected items to enhance the documentation; these were noted in the log. In addition, measurements were taken when appropriate (such as crack size), to determine the severity of the degradation.

Throughout the audit, Licensee representatives provided responses and documents in an effort to address and resolve many of the questions and concerns raised by the audit team during the formal presentation session and during the walkdowris. The audit team then reviewed and discussed the observations noted. A list of the more meaningful observations, including those that would be of benefit to the Licensee was compiled. The observations, which are discussed in the following chapters, were conveyed verbally to each Licensee at the exit meetings. 



\section{TROJAN NUCLEAR POWER PLANT}

Walkdown Description

July 23, 1991:

The walkdown for structures began inside containment. The audit team was separated into two teams ( $A$ and $B$ ). Team $A$ examined the polar crane, elev. 205' steel platform, and containment steel liner while Team B examined structures/supports internal to the bioshield. Then the two teams joined together to examine the remaining structures inside containment.

During the afternoon, Team $A$ examined the tendon gallery, outside containment near ground level, and areas of the turbine building. Team B examined areas of the fuel, aux, and control building.

July 24, 1991:

A formal presentation was made by Portland General Electric Company (PGE) personnel. Some of the topics covered include analysis/design criteria (seismic, tornado, codes/standards), performance of containment tendons, support anchorages, spent fuel pool and racks, intake structure, masonry walls, gaps between structures, groundwater problems, seismic instrumentation, tanks, and disposition of structural issues.

July 25, 1991:

During the morning period, Team A examined additional areas of the turbine building (emergency diesel generator room, turbine bay area, switchgear room, etc.) and the intake structure. Team $B$ examined the main steam support structure area and the tendon gallery.

During these activities, a third team was formed which reviewed and evaluated the 10 CFR 50.59 changes at Trojan. This team reviewed the Trojan Nuclear Division Procedure NDP 100-5 and the corresponding training module in detail to evaluate: (1) the effectiveness of the Licensee's training program to provide a thorough understanding of 50.59 requirements and (2) the procedures utilized to implement 50.59 evaluations for civil/structural related changes. The procedure establishes requirements for the preparation of safety evaluations required by NRC Regulations (10 CFR 50.54 and 50.59) and Section 6.5 of the Trojan Technical Specifications for changes to the facility, changes to procedures and licensing documents, and for conducting tests or experiments. It is used to document and ensure the completeness of safety evaluations and to determine whether NRC approval is required prior to implementing the change or conducting the test or experiment. 
The team selected and reviewed eleven 50.59 safety evaluation packages in detail. The team selected packages to review which provided a mix of different subjects, modification size, building location and safety impact.

\section{Results/Observations}

Containment-Interior

1. At Containment E1. 61' near the entrance to the pressurizer, the seal between the floor slab on top of the masonry wall and the liner plate appeared to be in poor condition. At El. 77' between azimuths $60^{\circ}$ and $90^{\circ}$, the seal between the floor slab and the liner is also in poor condition. At El. 77', there is evidence of deformation of flashing and grout between containment wall and internals. The concern is that water leakage through the seal could cause corrosion in the liner.

2. Ripples in the liner plate were observed at horizontal welds consistently around containmment. In addition, the containment liner plate at azimuth $300^{\circ}$, elevation $130^{\prime}$ had an inward horizontal bulge of approximately 1 1/2" that was tapered over a 10' vertical span. Bulges in the liner plate were also observed at both sides of the access hatch to containment at El. 45'. When the plate was tapped it sounded hollow behind the liner.

3. The paint on the containment polar crane runway rail girder and its supports was observed to be cracked and was peeling at various locations.

4. It was observed that the containment El. 205' structural steel under the air coolers had a white buildup on the surface.

5. At El. 45' azimuth $280^{\circ}$ inside the containment on the outside of the bioshield wall, it appears there was a baseplate with anchor bolts removed from the wall. On the face of the wall there are numerous horizontal and vertical cracks in the concrete.

6. On the pipe support that snubber $s S-1105$ is attached to, at the $45^{\prime}$ elevation inside containment near the recirc. sump, the nuts on the baseplate anchor bolts do not have full thread engagement.

7. Examination of the containment liner indicated that the liner plate had missing/peeling areas of coating at El. $45^{\prime}, 160^{\circ}$ azimuth.

8. Inside containment, rusting and lack of coatings was noted on several recently modified major pipe supports. 
Containment - Exterior

1. On the exterior of the containment structure it was observed that near the base, grease has been leaking from vertical cracks in the concrete spaced approximately $3^{\prime}$ on center (Plate 1).

2. On the exterior of the containment structure mid-height it was observed that at the construction opening a gutter has been installed to catch grease leaking from the construction joint (Plate 1).

Containment - Tendon Gallery (Plates 2 and 3)

1. A grease filler leak was noted at the cap seal on tendon $V$ 104. Grease leakage from the cap of V 116 and V 110 were also noted.

2. A conduit and short pipe section next to the inside wall across from V $201 \mathrm{~W}$ has rust deposits.

3. A lot of water was noted in the drainage slot next to the exterior wall and at the entrance sump. This suggests water infiltration has occurred.

4. Spalled concrete was identified on the floor next to the inside wall at the entrance azimuth.

5. What appears to be calcium carbonate deposits next to $V 216$ and V 108 were observed.

\section{Other structures}

1. Concrete cracking and evidence of relative displacement at joint between Area 12 and auxiliary building was noted.

2. Concrete cracking at the ceiling of the control building El. $105^{\prime}$ was observed.

3. In the auxiliary building at El. $77^{\prime}$ there are cracks in the wall at column line 55. Also some cracking was noted at El. $61^{\prime}$.

4. Rust was observed on support HBD-27-3 SR 813, El. 45' of the fuel building. Rust exists behind the baseplate with no visible water source. Support is on the Hut enclosure.

5. Rust marks were noted on a steam generator support base plate.

6. On the fuel building El. 77', Rm. $217 \mathrm{~s}$. Wall, cracks appear on the outside wall of the spent fuel pool cask loading pit. 
7. Cracking was observed at the discontinuity between EI. $61^{\prime}$ and 65" in control building "B" switchgear room. A crack in the floor at the East wall shows signs of spalling (Plate 5).

8. In the control room East wall, cracking appears to have reoccurred after grouting was performed.

9. At control building El. 65', in the East wall of the East battery room, cracking above the door was observed.

10. Cracks above fuel building, El. 45', were observed on the outside of the spent fuel pool walls near the junction of the basemat and wall.

11. Approximately 4 inches below the El. 93' slab on the turbine pedestal is a horizontal crack in the concrete.

12. At El. 25' in the turbine building, seepage from the walls and floors was observed (Plate 4). A 6" $x$ 3" section of concrete has spalled as a result of this condition.

13. Leakage of water from the spent fuel pool walls had occurred previously. PGE personnel were aware of this problem and had performed an evaluation.

14. Emergency diesel room "B", El. 45', North waIl; a large vertical crack in masonry wall was observed (Plate 4). Also, masonry wall spalling in "A" EDG $\mathrm{rm}$. behind electrical cabinet No. C101A was observed.

15. Diagonal cracks with paint covering most of them were observed at the West wall A - EDG room.

16. Diagonal wall cracks approximately $1 / 16 "$ were noted at El. 25' intake structure (Plate 4). In addition, stains streaking down this wall from the top were observed. 
Plate 1 - Trojan Nuclear Power Plant

Grease Leakage From Tendon Casings
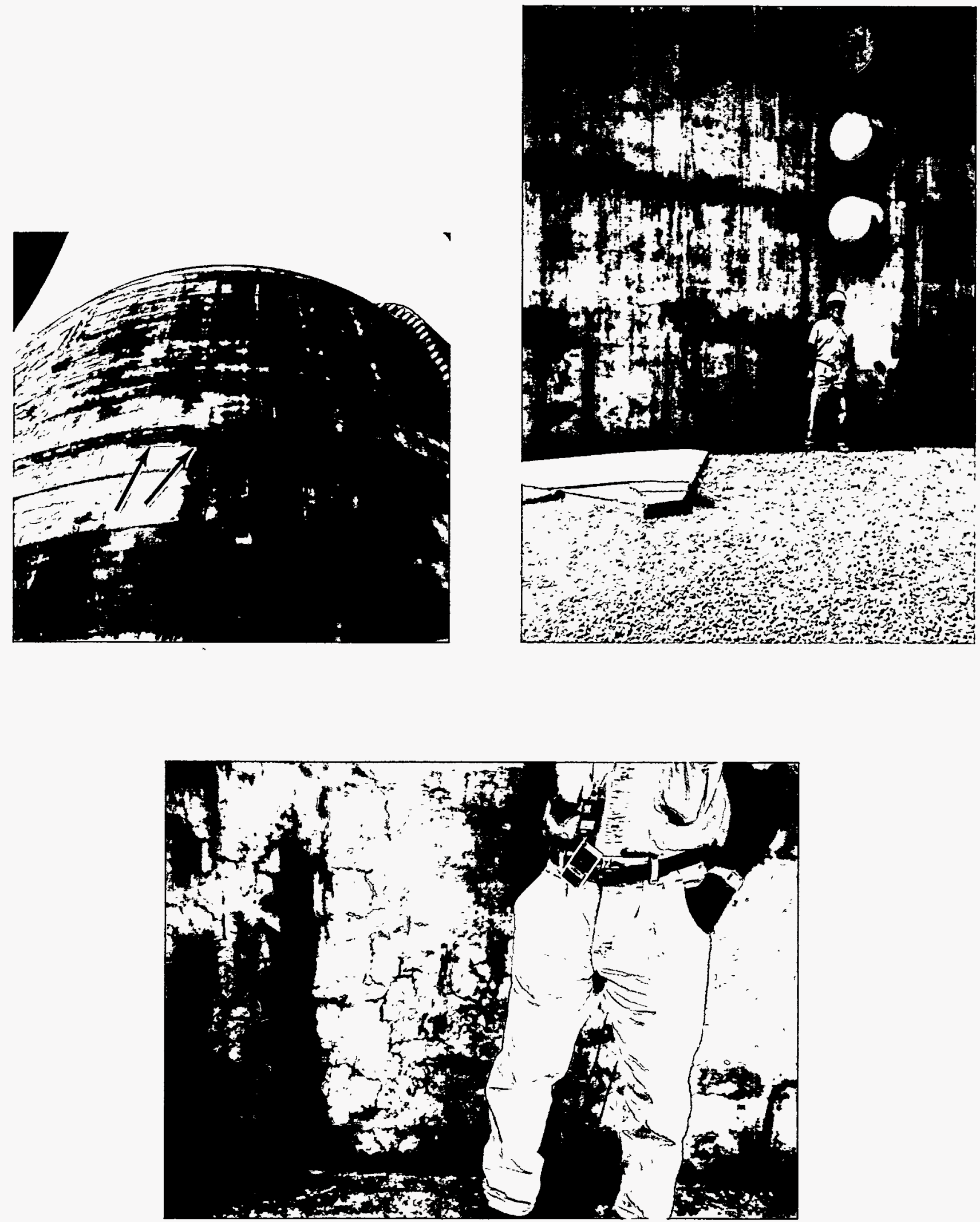

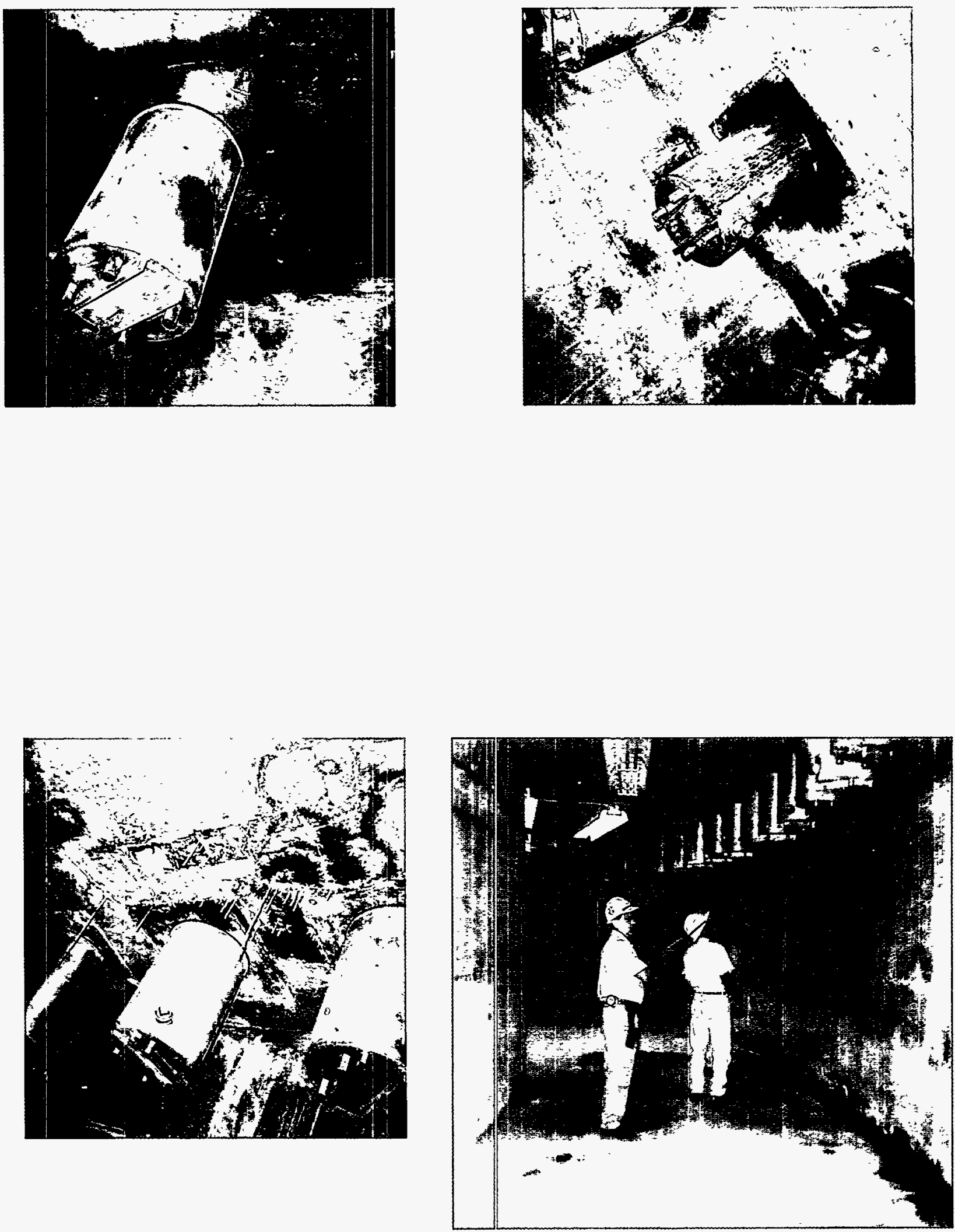


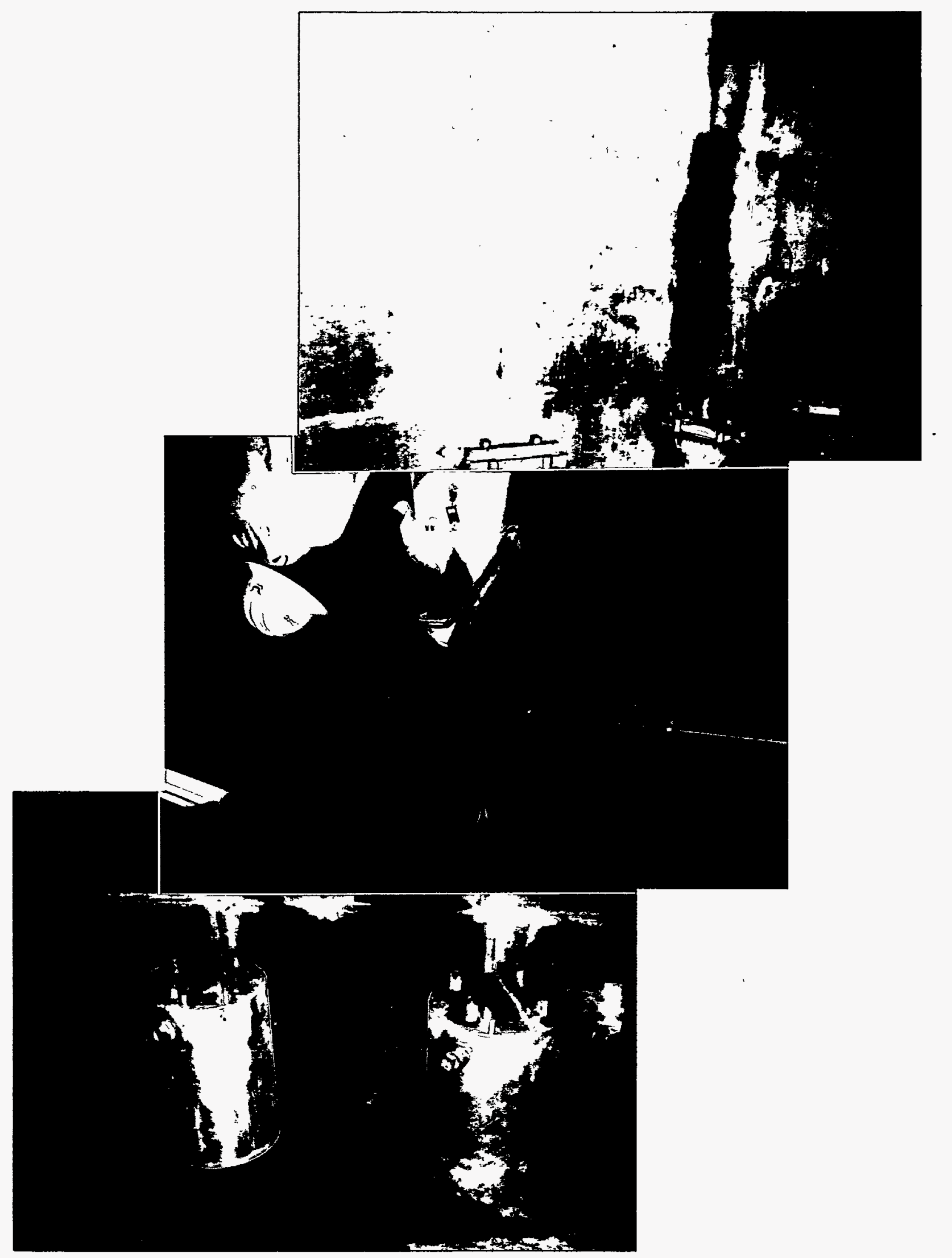

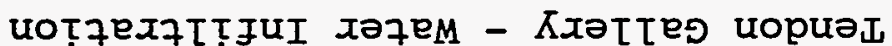

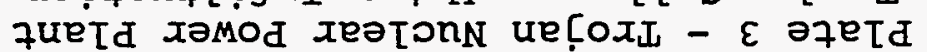


Plate 4 - Trojan Nuclear Power Plant

A- Turbine Building (EI. 25'); B- Intake Structure (El. 25')

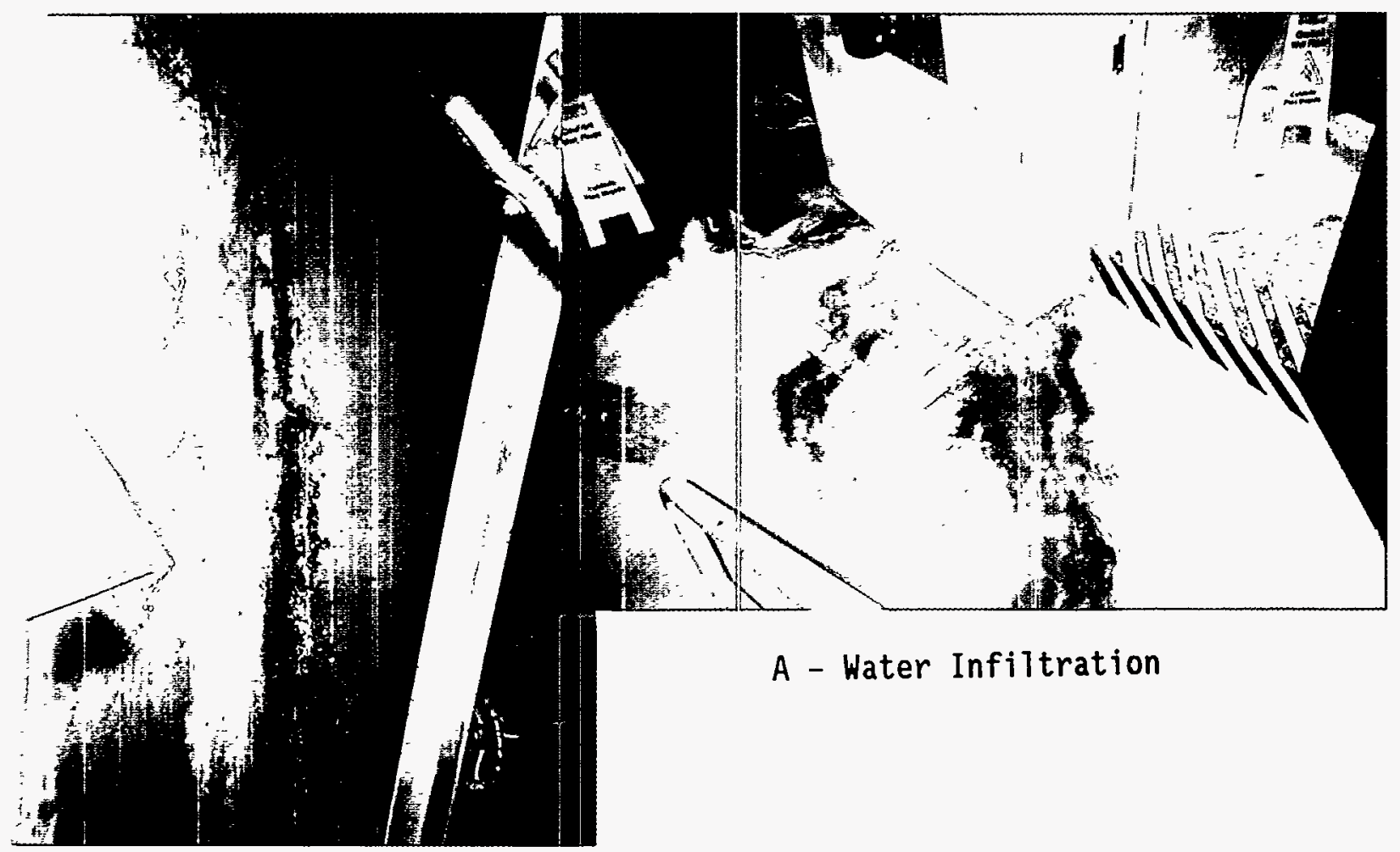

A - Concrete Degradation

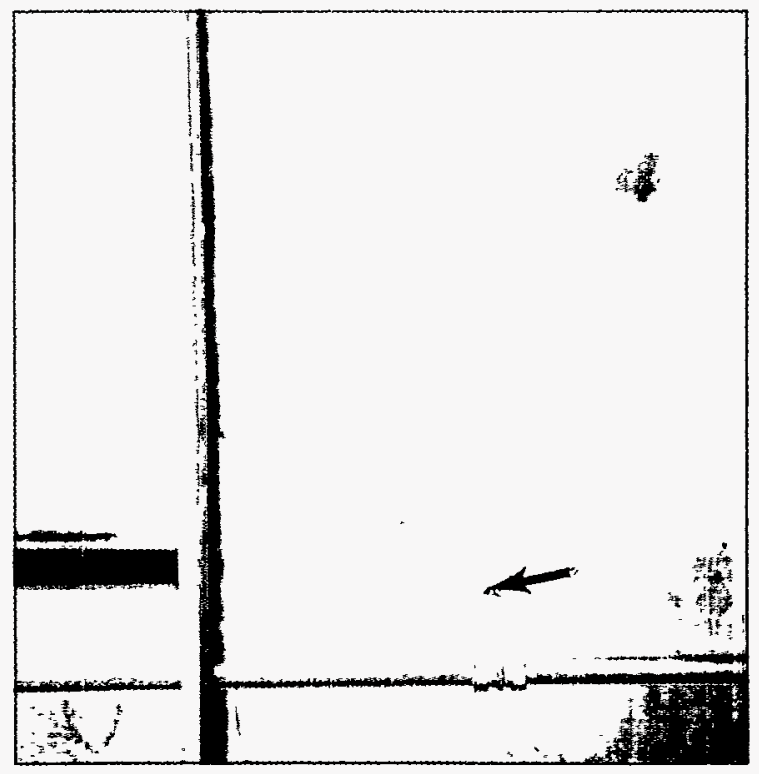

B - Diagonal Crack in Concrete Wall 


\section{Plate 5 - Trojan Nuclear Power Plant Control Building (El, 61')}

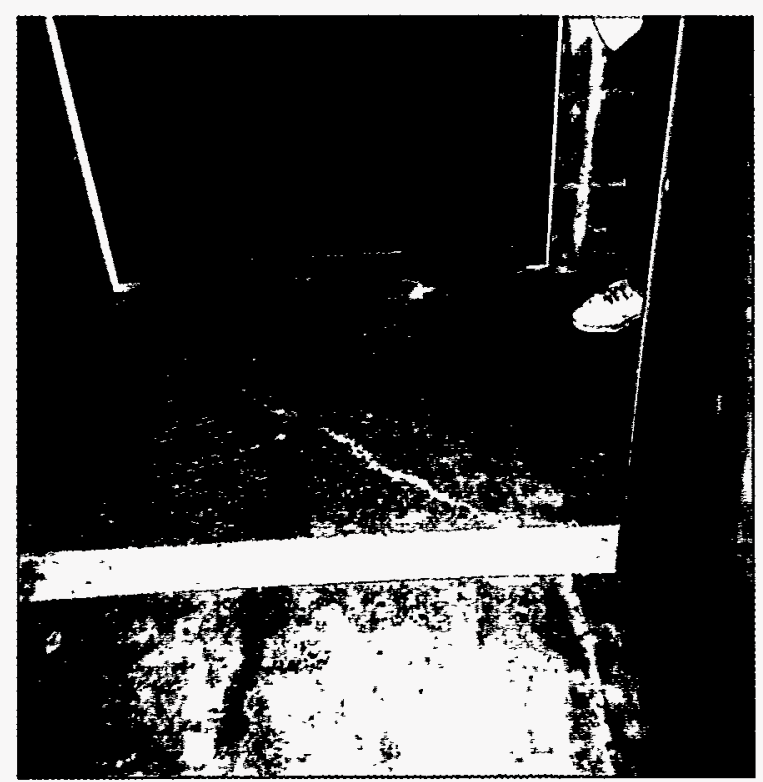

Concrete Crack in Floor
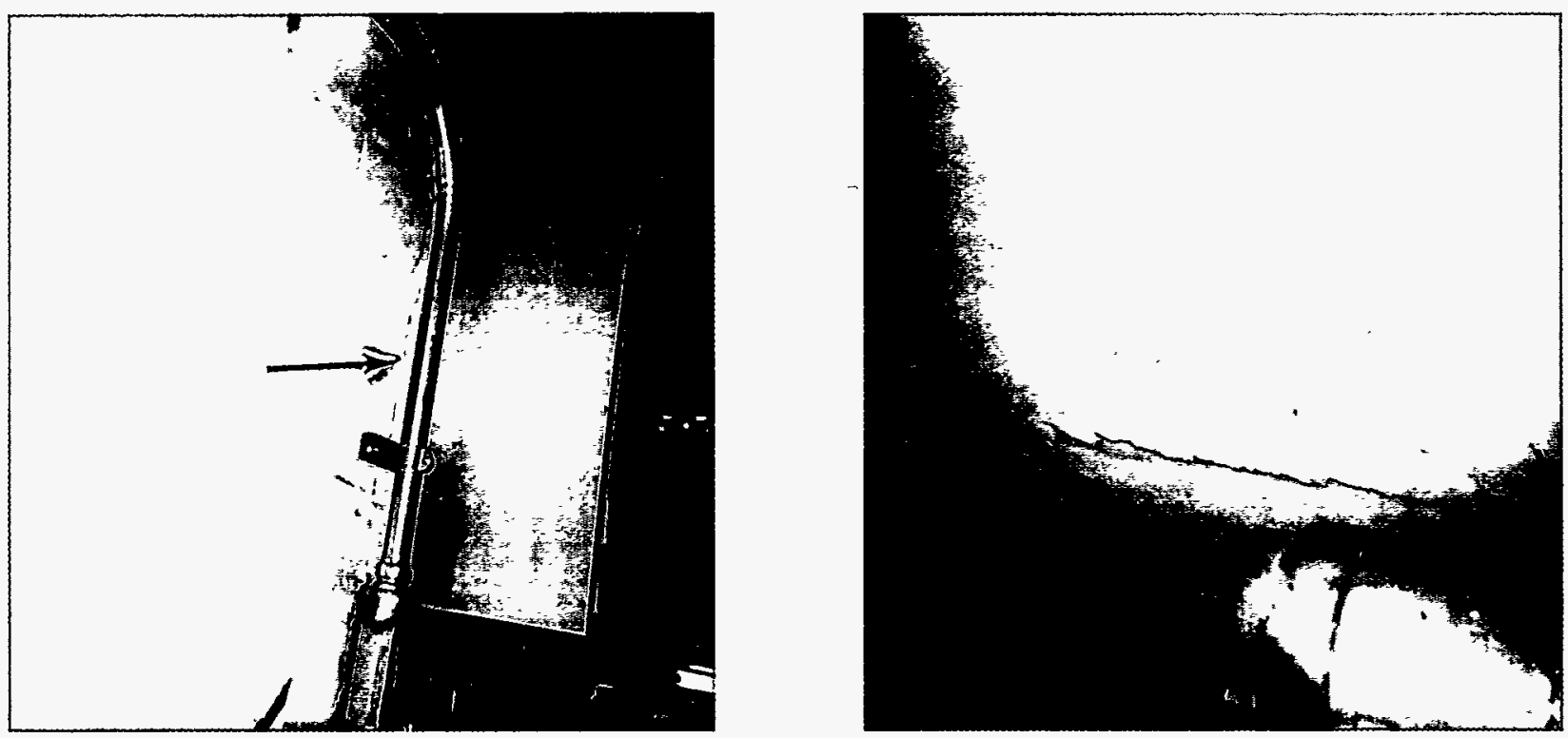

Cracks in Masonry Walls 



\section{POINT BEACH NUCLEAR PLANT - UNITS $1 \& 2$}

\section{Walkdown Description}

October 22,1991 :

A formal presentation was made by Wisconsin Electric Power Company (WE) personnel. Some of the topics covered include design/codes for category 1 structures, seismic design criteria, containment tendon surveillance, support anchorages, spent fuel pool and racks, intake structure, masonry walls, free spaces/settlement monitoring, and civil/structural LERs. Another important topic for discussion was the use of cathodic protection systems at the site for selected structural components, particularly the piles which support the two containments and fuel pool basemats.

October 23,1991 :

During the initial walkdown inside the Unit 2 containment, the audit personnel were separated into two teams ( $A$ and $B$ ). Team A began the walkdown inside containment from the top down, while Team $B$ conducted its walkdown from the basemat of the containment working up, until the two teams met.

Team A examined the polar crane and crane girder, containment liner dome region, and containment spray/supports from a distance, by standing on a steel platform beneath the crane girder. Team $A$ also examined the structural steel at the top of the shield wall surrounding the steam generator, the main steam pipe support anchorage to shield wall, supports to the accident fan coolers, conduit/supports, and the shield wall. In addition, the containment liner below the dome was examined up close at various elevations and near the containment personnel hatch and equipment hatch.

Team $B$ examined the accessible areas on Elevations $8^{\prime}$ and $21^{\prime}$. specifically, the containment liner; the "leak chases" which enclose the liner butt welds; the liner deflection monitoring gages; concrete floors and walls; structural anchorage to walls and floors; the service water piping; containment cavity cooling units; and containment penetrations were reviewed for signs of degradation and conditions which may warrant monitoring or remedial action.

In the latter part of the morning, the two teams joined to perform walkdowns of the Unit 2 tendon gallery, Units 1 \& 2 outside containment, and facade structure surrounding the containment. The entire tendon gallery was examined (all $\left.360^{\circ}\right)$ and included the concrete floor, walls, ceiling, tendon bearing plates, and tendon grease caps. The review of the outside containment encompassed the containment vertical wall, mat, and dome; buttresses; and tendon 
bearing plates/tendon grease caps. Although the facade structure was examined, it is not a Seismic Category I structure.

In the afternoon, the entire audit team examined areas in the auxiliary building (elevations $-19 \mathrm{ft}$ to $+26 \mathrm{ft}$ ), turbine building (elevations $8 \mathrm{ft}$ to $44 \mathrm{ft}$ ), control building (elevations $8 \mathrm{ft}$ to 44 ft) and fuel pool building. These reviews included walkdowns in the diesel rooms, cable spreading room, battery/rack room, vital switchgear room, and control room. Structural components reviewed include concrete floors, walls, and ceiling; conduit; cable tray; piping support anchorages; seismic gaps; equipment supports; tanks; and masonry walls.

October 24, 1991:

In the morning, the entire audit team examined the pumphouse (ground elevation); the fore-bay structure; the exterior walls of the auxiliary building, turbine building, and control building; the tornado missile protection for the cliesel generators; and the fuel oil pumphouse (including the fuel oil tank, pumps, and associated supports). In the water intake pumphouse, the primary areas of review included the pumphouse structure, North and south pump rooms, and equipment support/anchorages. The other areas include the fore-bay concrete structure, water baffle concrete structure, and discharge piping. The intake crib could only be visually observed at a distance since it is located 1750 feet offshore. The $14 \mathrm{ft}$. diameter intake piping between the intake crib and fore-bay structure is buried below the lake bed and obviously could not be viewed.

\section{Results/Observations}

Inside Containment (Unit 2)

1. At several locations inside containment, the liner plate is separated from the concrete. There is a concern that voids may exist in the concrete. Another potential concern is the one observed by Dr. Newmark in his report to the NRC (page 68, Appendix D) dated 3/11/70. The report described the possibility that a snap through of the liner plate could lead to larger than normal deformations. Although the liner separation is being monitored, no evaluation has been made.

2. Gouges in the liner of approximately 1/8" depth were observed at two locations (elev. 66' and about elev. 46'). The audit team asked if there is any acceptance criteria for such cases. $W E$ indicated that at least in one case the gouge was in existence at the time of construction and evaluated for acceptability. The staff suggested that criteria should be established to evaluate the acceptability of any gouges in the liner that may occur in the future, during refueling outages or repair work. 
3. Extensive corrosion and paint blistering was identified in the service water piping and associated valves. Substantial corrosion was also noted on the containment cavity coolers. WE has replaced some of the piping in the service water piping system and is examining the cause of this degradation to prevent its occurrence in the future.

4. In several locations (e.g., elev. $66^{\prime}$ East side) the liner paint has either peeled off or was scratched. In addition, some structural supports inside containment (at top of shield wall) were not painted/coated. WE has no acceptance criteria or procedure for the evaluation or repainting of these surfaces.

outside Containment

1. At the buttresses, substantial corrosion of the tendon plates and grease caps was observed at several locations (Plate 6).

2. Grease leakage was found at several horizontal tendons (e.g., Unit 1 , buttress A, azimuth $250^{\circ}$ ). In addition, grease leakage (possibly from a vertical tendon) to the outside surface of the containment concrete wall was located at Unit 2 Elevation $6^{\prime}-6^{\prime \prime}$ near azimuth $350^{\circ}$ (Plate 7).

3. Horizontal cracks in the buttresses along the centerline of the hoop tendons were found at a number of locations (e.g. Unit 1 , buttress $D$, azimuth $70^{\circ}$ ) (Plate 7 ). It was suggested that WE may want to determine if the tendons associated with the largest concrete cracks lose prestressing force more than the other tendons.

4. Chunks of concrete were missing at the edge of several buttresses, next to bearing plates for the hoop tendons. An example of this is Unit 1, Elevation 85', Buttress D (Plate 6).

5. Minor radial cracks on the concrete ledge of the containment foundation mat were observed, uniformly spaced around much of the containment. These cracks were more numerous in Unit 1 than Unit 2 .

6. In the Unit 2 tendon gallery, groundwater was seeping in through cracks in the walls and ceiling at several locations. Corrosion in the vertical tendon bearing plates and localized degradation of concrete was observed (Plate 8).

7. WE relies on cathodic protection systems (CPS) to prevent corrosion of the steel piles which support the containment and fuelpool basemats. Based on CPS operating data, WE has concluded that the system is functioning properly and consequently, preventing corrosion. No visual or other verification means have been attempted. The audit team could 
not conclude based on WE's input whether or not CPS is effective in eliminating corrosion of the piles. Additional information on CPS and data on long term integrity of steel piles need to be reviewed as part of the assessment of this issue.

The audit team expressed the opinion that physical inspection of a properly selected sample is required to assess the performance of cathodic protection systems in preventing corrosion of the piles and to assess the current condition of the piles.

Intake structure (Crib and Forebay)

1. Because the fourteen (14) ft. diameter intake pipes were inaccessible, the audit team could make no observations nor draw any conclusions. WE indicated that periodic inspection is performed using divers and no significant indications of degradation have been reported. It was pointed out by $G$. Bagchi that if significant leakage develops through the joints of this piping, the surrounding soil can be dissolved/removed leading to the development of large voids in the ground causing foundation failure. This situation occurred at the Bailey fossil fuel power plant.

2. WE's diving inspection procedure used for the crib structure and forebay area of the pumphouse was reviewed. Although the procedure calls for various observations to be made, it does not include inspection of damage to concrete structures. It was suggested that the procedure be revised to include inspection for damage to concrete structures, so that timely repairs can be made if needed. No conclusions for submerged structures could be reached due to lack of accessibility and inspection data.

3. The concrete surrounding the two large discharge pipes has developed cracks and appears to have degraded chemically.

Pumphouse

1. There are a number of cracks in the exterior concrete walls and roof of the pumphouse. The cracks in the roof show some signs of water infiltration and possible concrete degradation.

2. The grout beneath some of the safety-related equipment base plates is severely degraded. In some cases a significant portion of the grout is missing. The equipment is located in the North and South service water pump rooms. Examples where this problem exists is beneath the screen wash pump check valve, service water pump $\mathrm{P}-32 \mathrm{E}$, and the Zurn strain-o-matic base plates (Plate 9). 
Auxiliary Building

1. In the central auxiliary building, elevation -19', there are several small cracks in the concrete walls. In addition, groundwater is seeping in through the floor and some of the cracks in the walls. The walls show sign of calcium formation and the floor has a bulge where the ground water has infiltrated (Plate 10). All of these indicate that some concrete degradation has occurred.

2. Also, in the central portion of the auxiliary building, on the West side, there are two large vertical cracks. These may need to be monitored.

other

1. A seismic gap at the front wall and basemat elevation between the control building and turbine building could not be located. According to $\mathrm{WE}$, a 2" seismic gap should be present between structures to accommodate building seismic movement.

2. Anchor bolts/nuts in several equipment supports did not have full thread engagement. Examples of this include the starting air receiver tanks for the diesel generators.

3. There is no surveillance/visual examination program for the identification and subsequent repair of cracks in seismic category 1 masonry walls. This is important since the seismic calculations assumed the masonry walls were unreinforced and thus relied on the full bending capability of the masonry walls (without cracks).

4. Concrete cracks were observed above the two diesel generator exhaust piping penetrations, on the exterior of the emergency diesel generator building East (lakeside) wall.

5. In various areas where groundwater seepage is occurring it may be necessary to test core samples to determine whether or not there is any concrete strength reduction. Reduction in strength may occur due to loss of alkalinity.

The following items were observed for non-safety-related structures/components or are not directly related to aging degradation:

1. In the turbine building, Elevation $26^{\prime}$, at Valve No. 1P/P-481, there is visible vibration of the piping and apparent shifting of the deadweight support stanchions.

2. Inservice surveillance reports for containment were requested to gain insights on trends of the loss of prestressing force. 


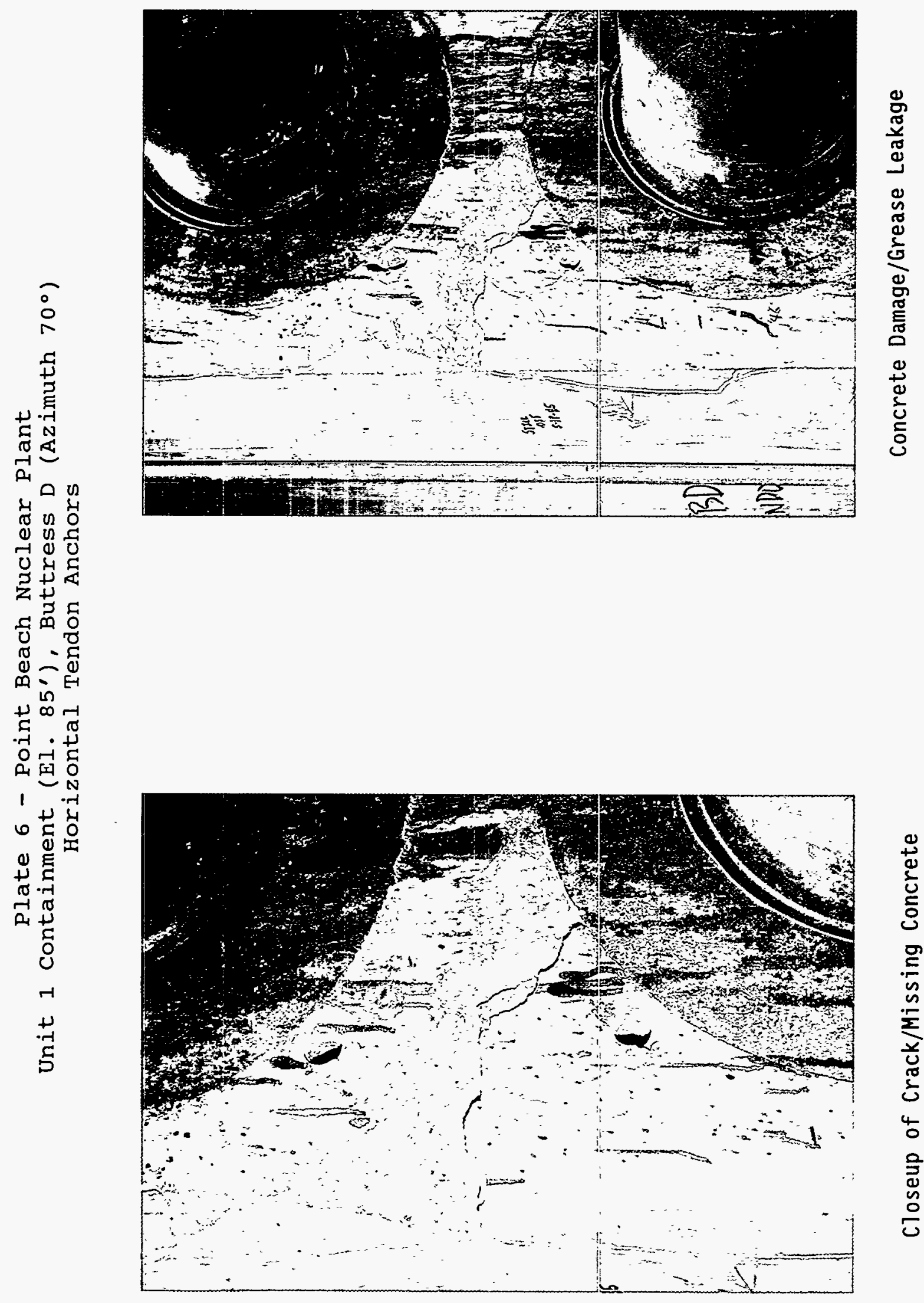


Plate 7 - Point Beach Nuclear Plant

Unit 2 Containment - Miscellaneous observations

Dי
0
0
0
0
0
0
0
0
0

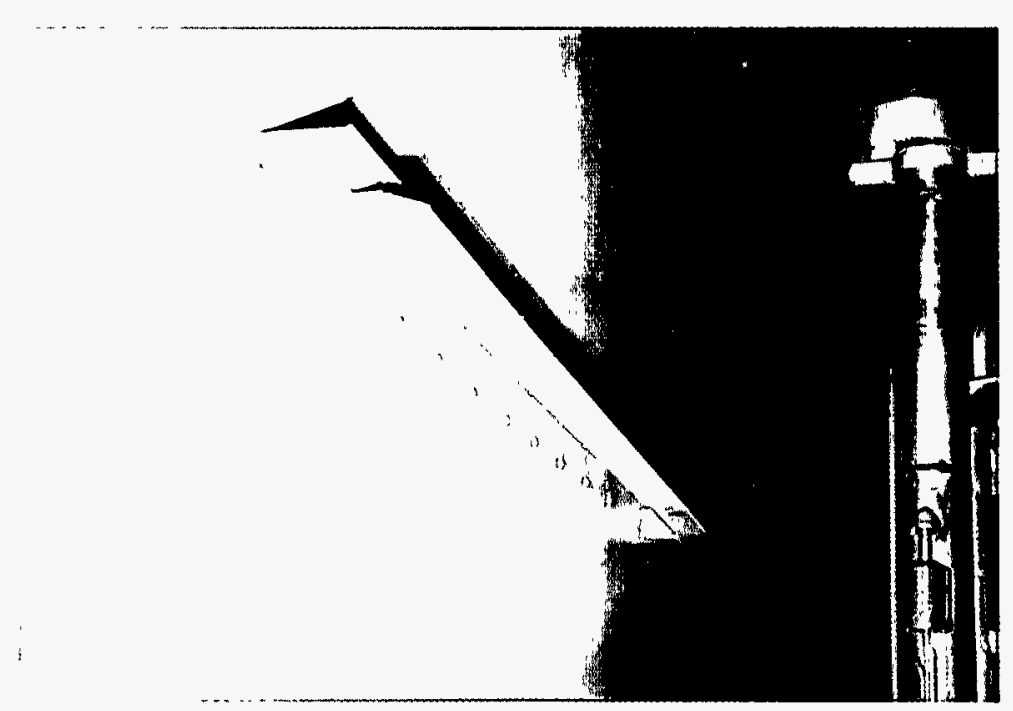

1

Liner Monitoring Gage at El. 21' (Typical)
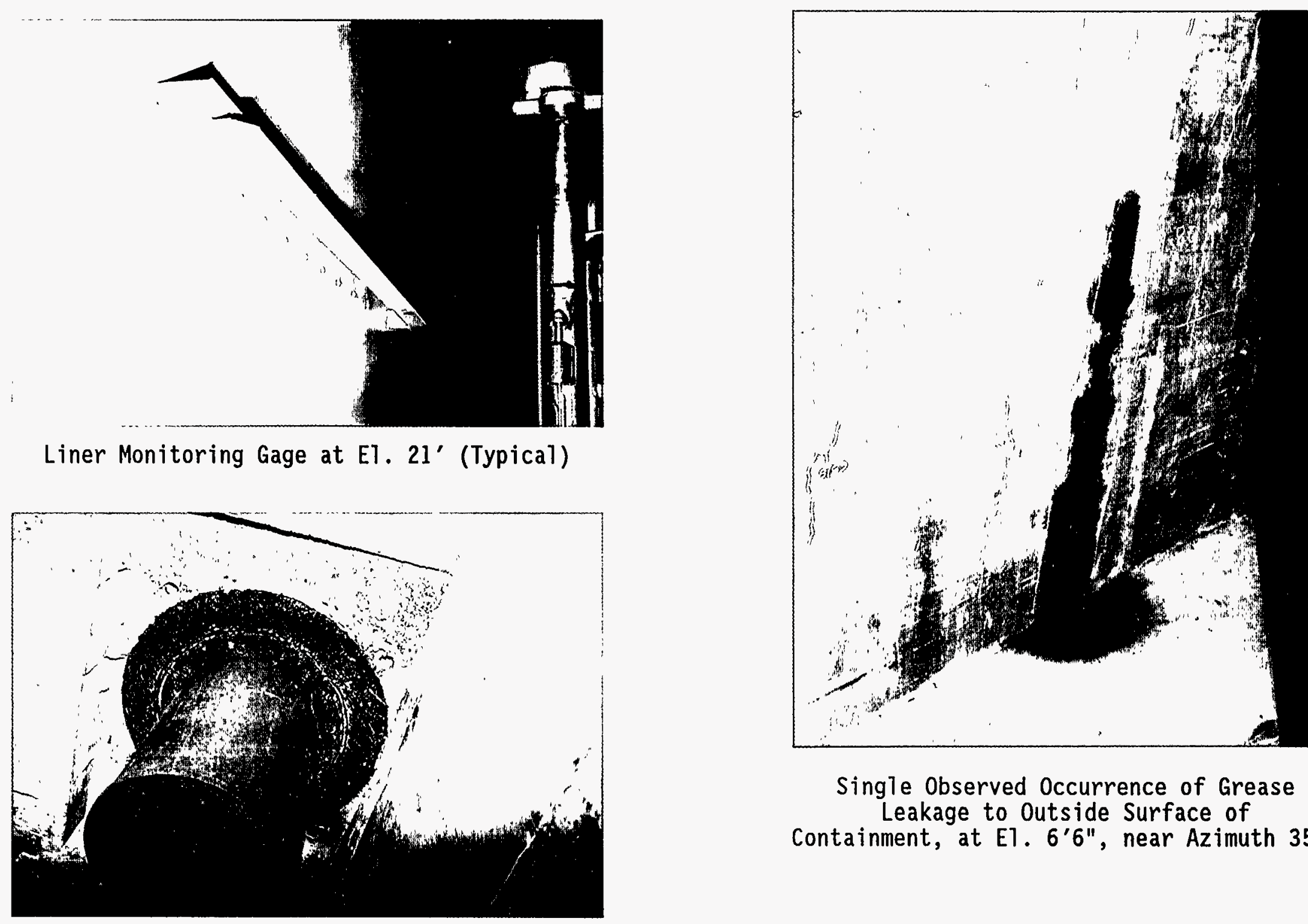

Single Observed 0ccurrence of Grease Leakage to Outside Surface of Containment, at El. 6'6", near Azimuth $350^{\circ}$

Worst Case of Anchor Corrosion Observed in the Vertical Tendon Gallery 
Plate 8 - Point Beach Nuclear Plant

Unit 2 Tendon Gallery

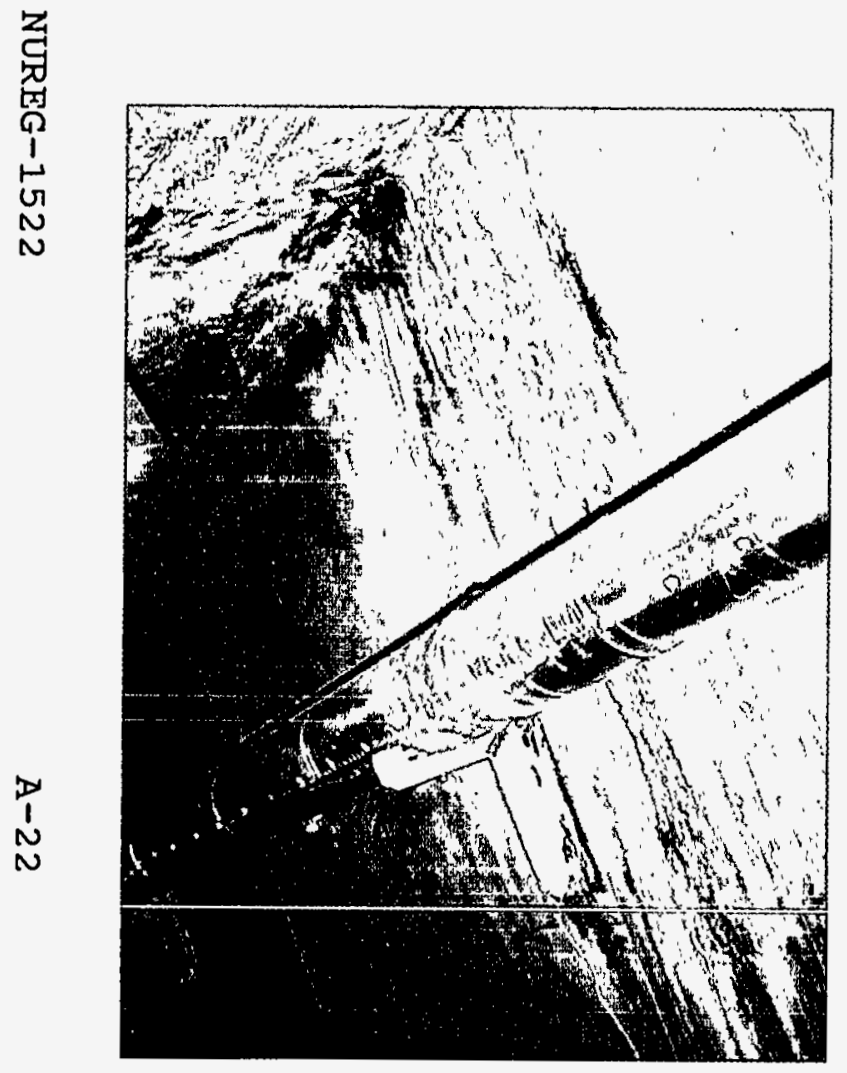

Water Dripping From Ceiling to Floor Near Tendon 212

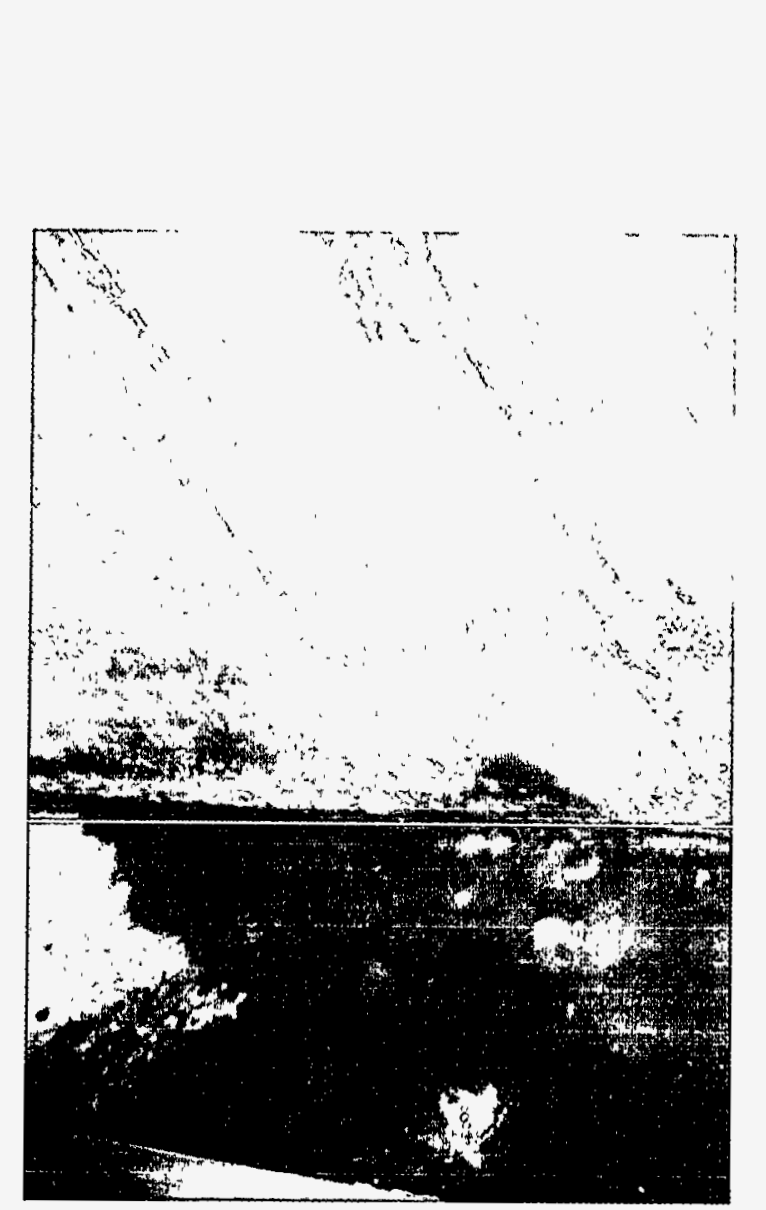

Floor Below the Water Drip Showing Mineral Deposits Near Tendon 212

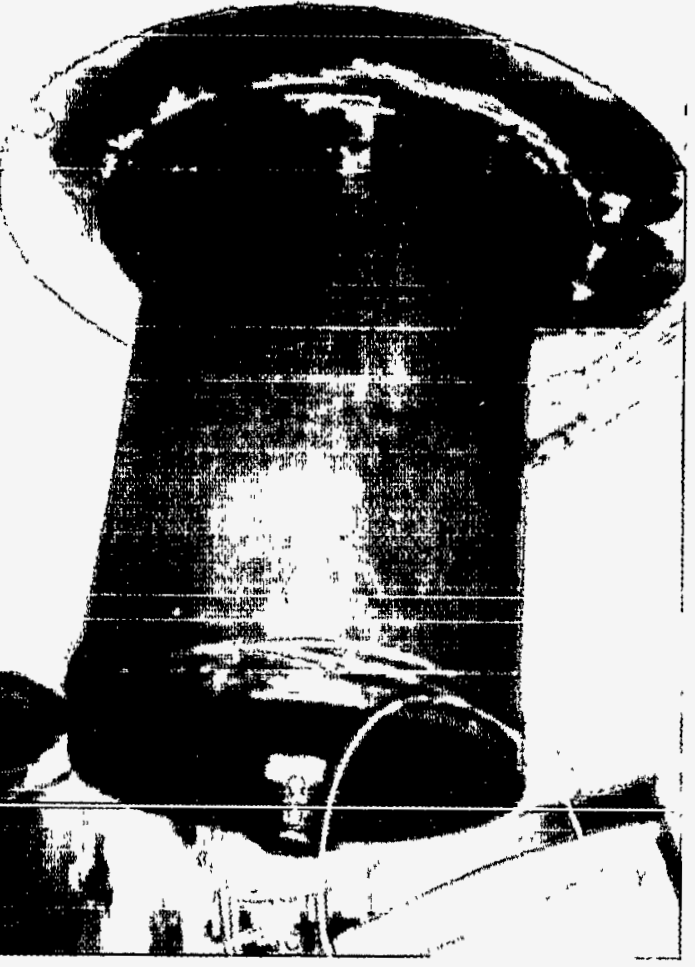

Grease Leakage at Tendon 291 
Plate 9 - Point Beach Nuclear Plant

North Service Water Pump Room - Grout Degradation

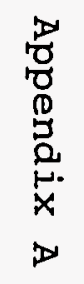

$\underset{\substack{1 \\ \omega}}{\sim}$
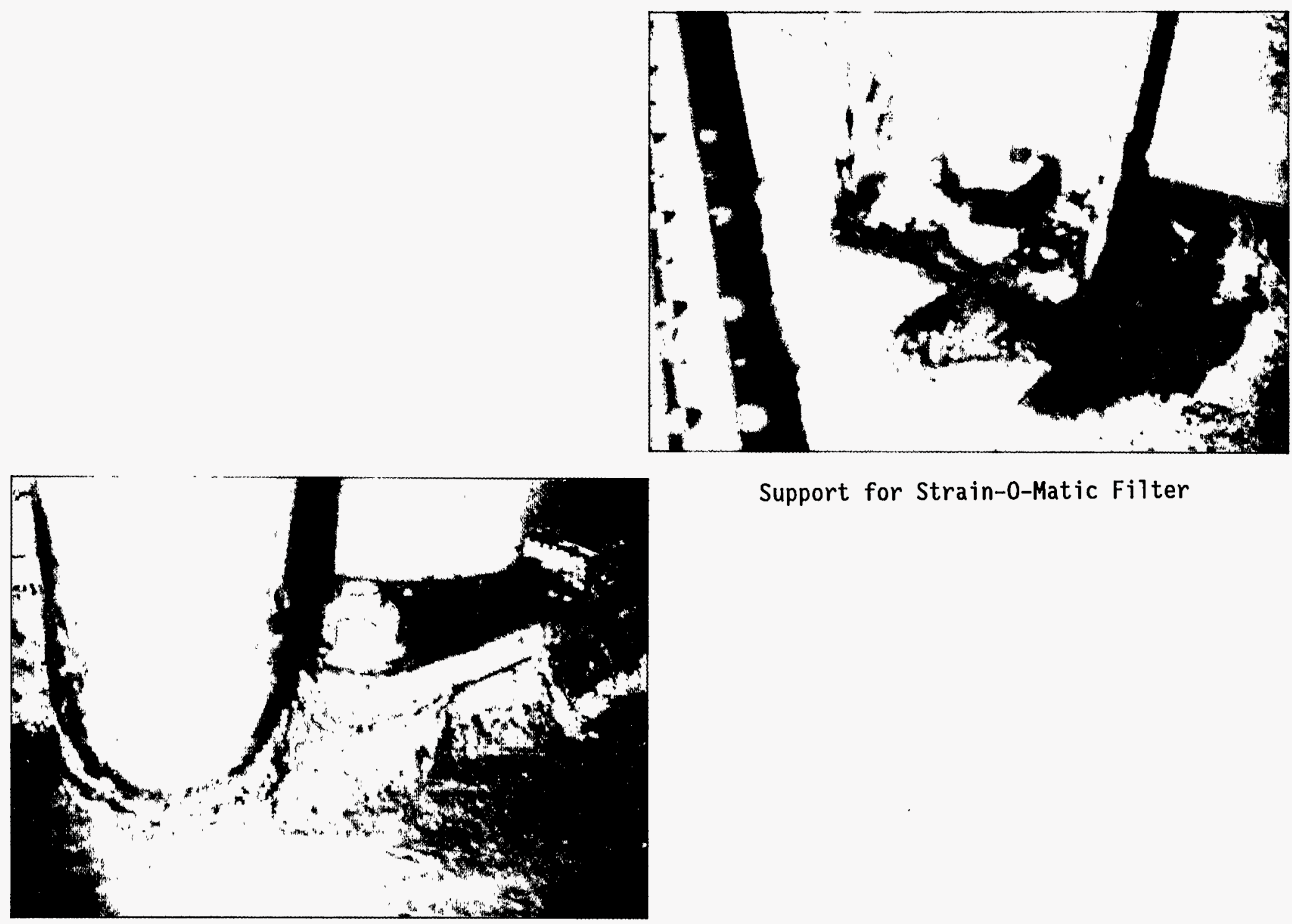

Support for Strain-0-Matic Filter

Support for Service Water Pump 
Plate 10 - Point Beach Nuclear Plant

Central Auxiliary Building - Evidence of Water seepage

$Z$
$C$
000
0
0
1
$心$
$N$
$N$

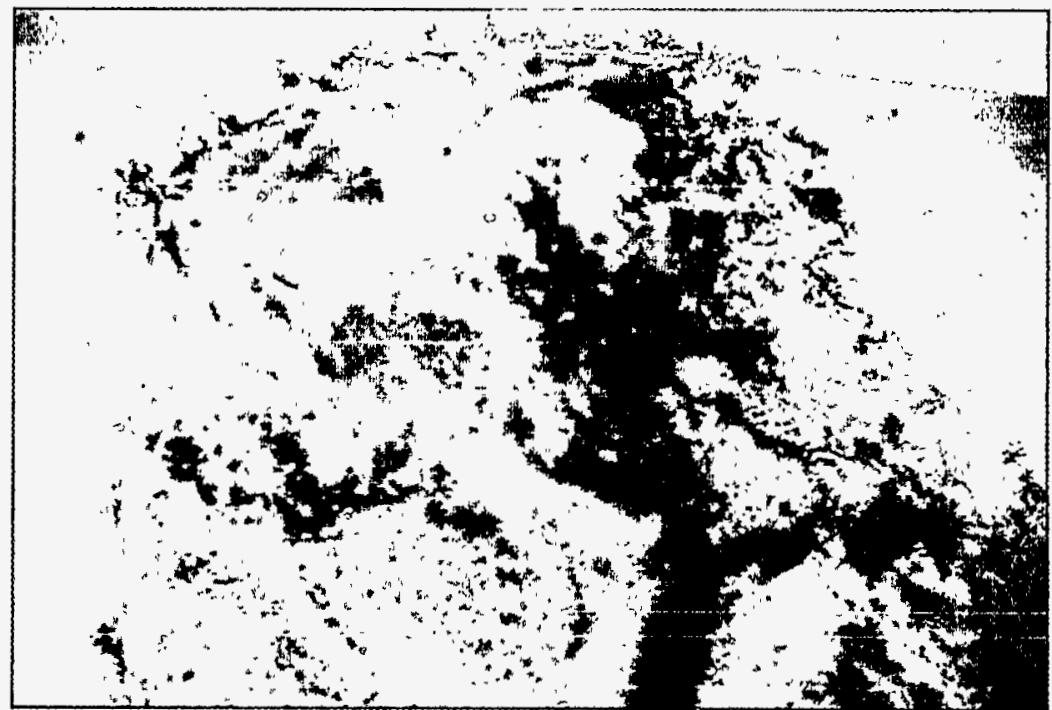

N

Basemat, EI. 19' - Crack in Floor/Bulge in Concrete

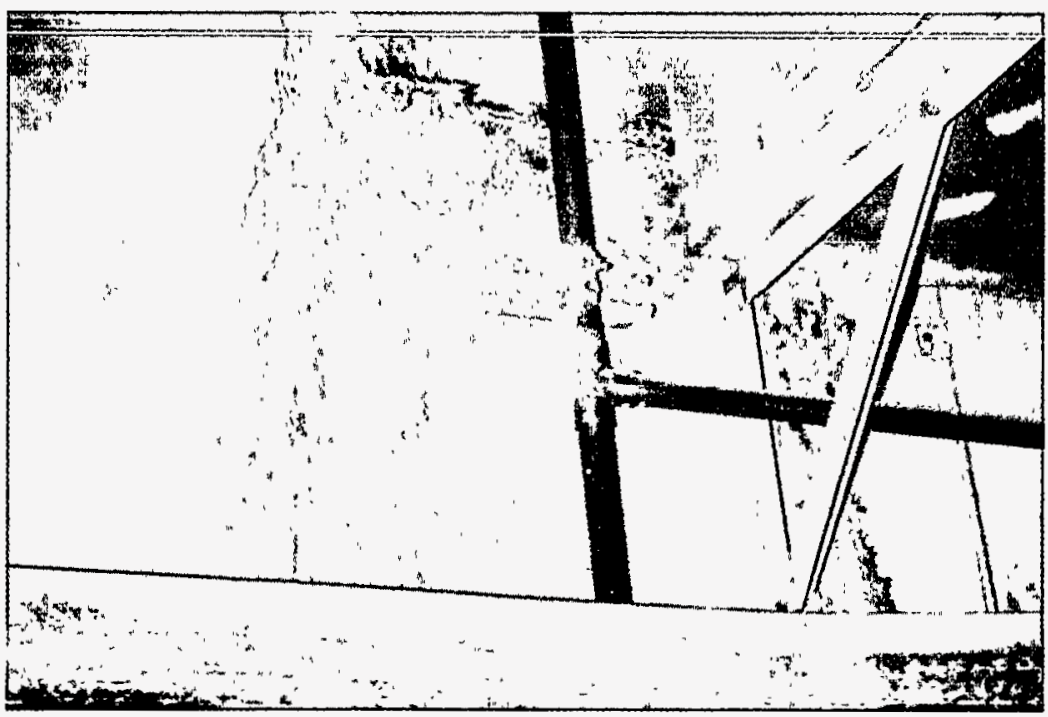

West Wa11, E1. 5' - Water Source Unknown

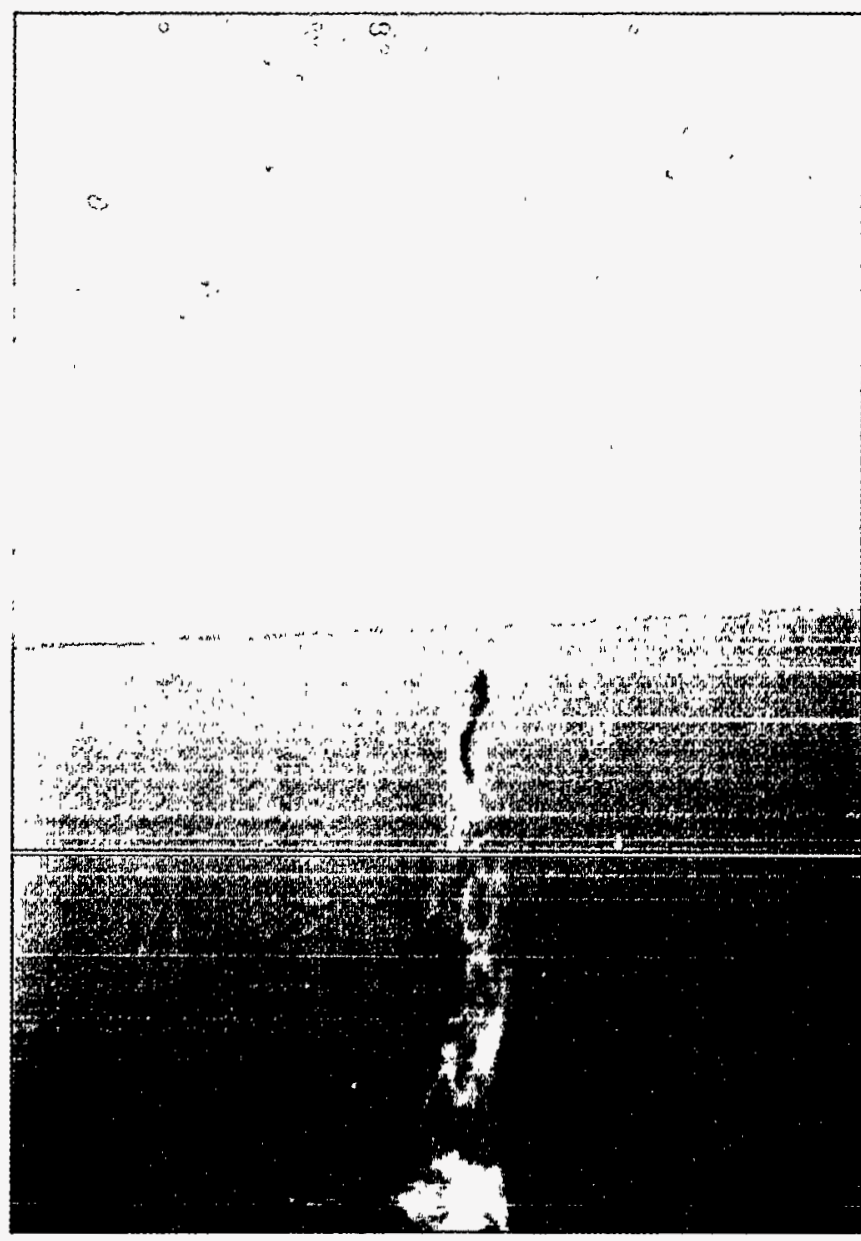

RHR Pump Room - Floor-to-Ceiling Crack 


\section{TURKEY POINT NUCLEAR POWER PLANT - UNITS $3 \& 4$}

\section{Walkdown Description}

A formal presentation was made by Florida Power and Light Company (FPL) personnel. The major topics covered include design criteria, containment structures, support anchorages, spent fuel pool and racks, intake structure, masonry walls, structural boundaries, geology/foundation conditions, maintenance of structures, seismic instrumentation, civil/structural LERs, past structural issues, civil/structural 10 CFR 50.59 evaluations, and emergency plans for natural emergencies.

January 15, 1992:

The audit team stayed together during the entire walkdown except as noted later on January 16, 1992. Since both nuclear units were operating, no walkdowns could be made inside containment. The audit team began the walkdown in the tendon gallery beneath the Unit 3 containment. The entire tendon gallery was examined $\left(\operatorname{all} 360^{\circ}\right)$ and included the concrete walls, floor, ceiling (bottom of mat), tendon bearing plates, and tendon grease caps. The review of the outside containment encompassed the containment dome, ring girder, wall, tendon buttresses, tendon bearing plates and tendon grease caps.

The containment dome was closely examined for any signs of delamination which occurred following original construction of the containment. At that time, the exterior concrete layer of the dome separated from the tendon layer. FPL described the repair made to correct this problem in their formal presentation. It consisted of removing the delaminated layer, placing radial reinforcement, and pouring a new concrete layer to repair the dome.

In the afternoon, the audit team examined areas in the Unit 3 spent fuel pool building, accessible portion of the containment mat, auxiliary building, control building, and Unit 4 switchgear building. These walkdowns included the cable spreading room, battery room, control room, roofs of the spent fuel and auxiliary building, 4160 Volt switchgear room, 480 Volt load center area, air handling equipment room, computer room, seismograph pit, cathodic protection system terminal panel area, $C C W$ heat exchanger room, RHR heat exchanger room, and the RHR pump room. Structural components reviewed in these areas include concrete floors, walls, and ceilings; building structural steel; conduit/supports; cable tray/supports; piping support anchorages; seismic gaps between buildings; equipment supports; tanks; and masonry walls. 
January 16, 1992:

In the morning, the audit team examined the Unit 3 and 4 emergency diesel generator buildings, diesel oil tank for unit 3 , condensate storage tank, and Unit 3 and 4 intake structure. In the emergency diesel generator building the structural components reviewed include the concrete floor, walls, and ceiling; diesel support frame/anchorage; day tank anchorage; and electrical equipment support/anchorage. In the intake structure, the structural components reviewed include the concrete floor; partially accessible portions of the CW pump concrete support beams and walls; and concrete walls at the East side of the intake structure and the screen washout area. Since both units were operating, it was not possible to view the concrete walls and slab below grade from inside the intake structure. However, photographs taken by FPL inside the intake structure below grade were made available and were reviewed by the audit team later in the day.

In the afternoon, the audit team split into two groups. The first group consisting of two audit members covered the 10 CFR 50.59 evaluation review. The second group consisting of the remaining members of the audit team examined the cooling canals.

A FPI representative made a short presentation to the first group describing the 10 CFR 50.59 Program and Initiatives. The presentation covered the procedures and guidelines, review and approval process, training, and recent initiatives to improve the program.

The second group was driven by an FPL representative around the perimeter of the cooling canals. Several stops were made to more closely examine the canals. FPL originally released the cooling water discharge directly to the ocean. However, due to environmental concerns, a cooling canal system was constructed to service both nuclear units and the fossil units at Turkey point. It is an extensive canal system consisting of canals 200 feet wide and spanning 168 miles in total length.

Upon completion of the canal system examination, the audit team reassembled to review representative 10 CFR 50.59 evaluation packages related to the civil discipline. A limited review was made on PCM 79-015, 82-148, 83-050, and 90-472.

\section{Results/Observations}

Outside containment

1. Water accumulation in the Unit 3 containment vertical tendons has been observed during tendon surveillance. However, no water accumulation has been observed in Unit 4 containment vertical tendons. Expanded vertical tendon surveillance for the presence of water for Unit 3 would provide additional data to determine the extent of water accumulation. 
2. In the Unit 3 tendon gallery, some of the bearing plates show signs of corrosion; there are cracks and voids in the concrete adjacent to the bearing plates; and there is a gap between the tendon gallery wall and the ceiling which allows water infiltration (Plate 11).

3. Near the junction of the Unit 3 containment dome and the ring girder there is a discoloration which appears to be due to poor water drainage. Some scaling of Unit 3 dome was observed (Plate 12).

4. Two spare penetrations in the Unit 3 containment wall at approximately elevation $30 \mathrm{ft}$. azimuth 226 degrees are not capped at the outside surface of the concrete containment. They go completely through the concrete wall (approximately $4 \mathrm{ft.})$ and are capped at the liner plate.

Inside Containment (Based on ILRT report for Unit 4)

1. In some areas of the containment liner, the top coat peeled, delaminated, and disbonded.

2. Surface corrosion of some of the liner seam welds and a few penetration canisters was observed.

3. Joint filler material between the liner and adjacent concrete structures was leaching in some areas.

4. Radially inward bulging of the liner was observed at the operating deck level and above the polar crane girder level. The bulging is random but widespread around the perimeter of the containment. The bulges run the entire height of the 10 ft. liner panel, are about 15 inches wide (liner stiffener spacing), and are deflected about $1 / 2$ inch radially inward at the middle of the panel.

5. Two $1 / 16$ inch cracks originating at the lower corners of a duct penetration through the $4 \mathrm{~B}$ steam generator cubicle wall were found.

\section{Intake structure}

We recognize that FPL is aware of the deteriorating condition of the intake structure and of the corrective actions it has taken for some of these areas. The audit team reviewed a report on the intake structure prepared by a consultant to FPL. The report indicates that the bay walls are also degrading and experiencing active corrosion of the reinforcing bars (Plate 13). Therefore, the audit team recommended that the licensee also give close attention to other parts of the structure such as the intermediate and exterior walls. 
Spent Fuel Building

The ceiling of the Unit 3 spent fuel building has a discoloration over an area of about 3 by 6 feet (Plate 14).

Tanks

1. Unit 3 condensate storage tank (Plate 15):

There are bent plates on the anchor bolt chairs.

There is deterioration of the water seal at the base of the tank and corrosion of the tank bottom plate is visible.

In a few places there are signs of corrosion and scratches and gouges on the tank wall.

2. The diesel oil tank does not have washers between the nuts and the anchorage plates.

Masonry Walls

For unreinforced masonry walls the seismic qualification relies on the assumption that there are no cracks in the wall. However, there appears to be no formal monitoring program to confirm that no cracks develop.

In the air handling room in the control building at elevation 30 ft., the angle support at the ceiling is not flush with the masonry wall (Plate 14).

Cathodic Protection System

A Cathodic Protection System (CPS) was installed during original construction to protect the containment-liner plate, reinforcing steel, and tendon assemblies. The system is presently exhibiting low to very low readings in some of the anodes. FPL is presently evaluating the effectiveness of the CPS.

Holes in Concrete structures

In some concrete walls, abandoned anchor holes, drilled holes, or holes from original construction have not been grouted. One example is the 9 inch deep holes on the exterior concrete wall of the Unit 3 containment.

Seismic Instrumentation

The following item is not related to aging degradation effects but was brought to the attention of FPL for their benefit.

Appendix A to $10 \mathrm{CFR}$ Part 100 states that if the vibratory ground motion from an earthquake exceeds the plants operating basis earthquake, the plant will be required to shutdown. The NRC staff 
has developed guidelines it will use to make plant shutdown recommendations. The consequences of the guidelines is based on the ability of the plant to provide prompt information about the earthquake.

Turkey Point has only one three-component accelograph that records photographically. It requires three hours to develop the film after the instrument trigger is detected. Prompt analysis of the photographic record could only provide peak ground acceleration. To obtain response spectra, the records would have to be digitized and used to generate response spectra. This could take a considerable time.

EPRI has developed an OBE exceedance criterion based on a damage threshold estimate. To use the EPRI criterion, digital recording and the generation of response spectra and cumulative absolute velocity are required. The ability to do this can provide the information to avoid unnecessarily shutting the plant down in the event of a nondamaging earthquake which has short duration high frequency exceedance of the OBE. 


\section{Plate 11 - Turkey Point Nuclear Power Plant Unit 3 Tendon Gallery}

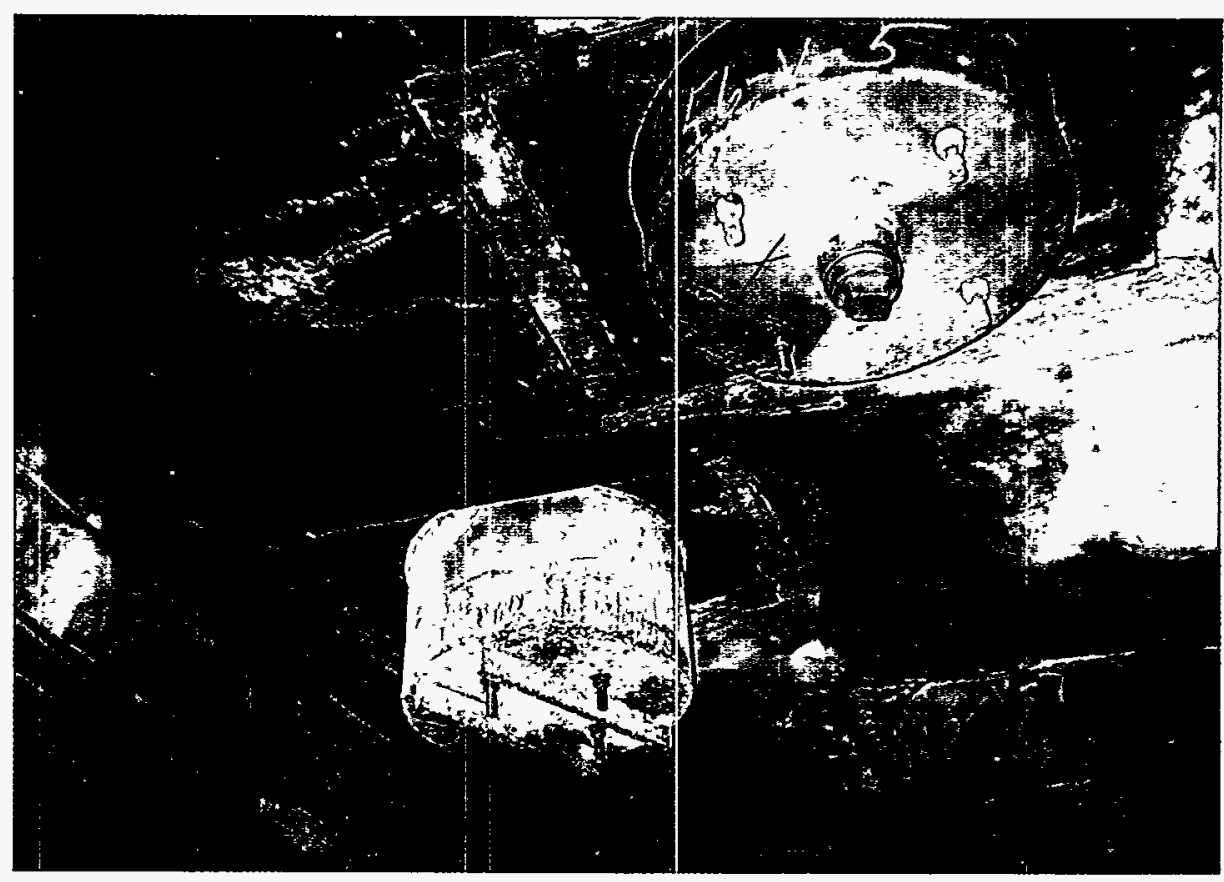

Grease Leakage at Tendon 56-V-5 (Typical)

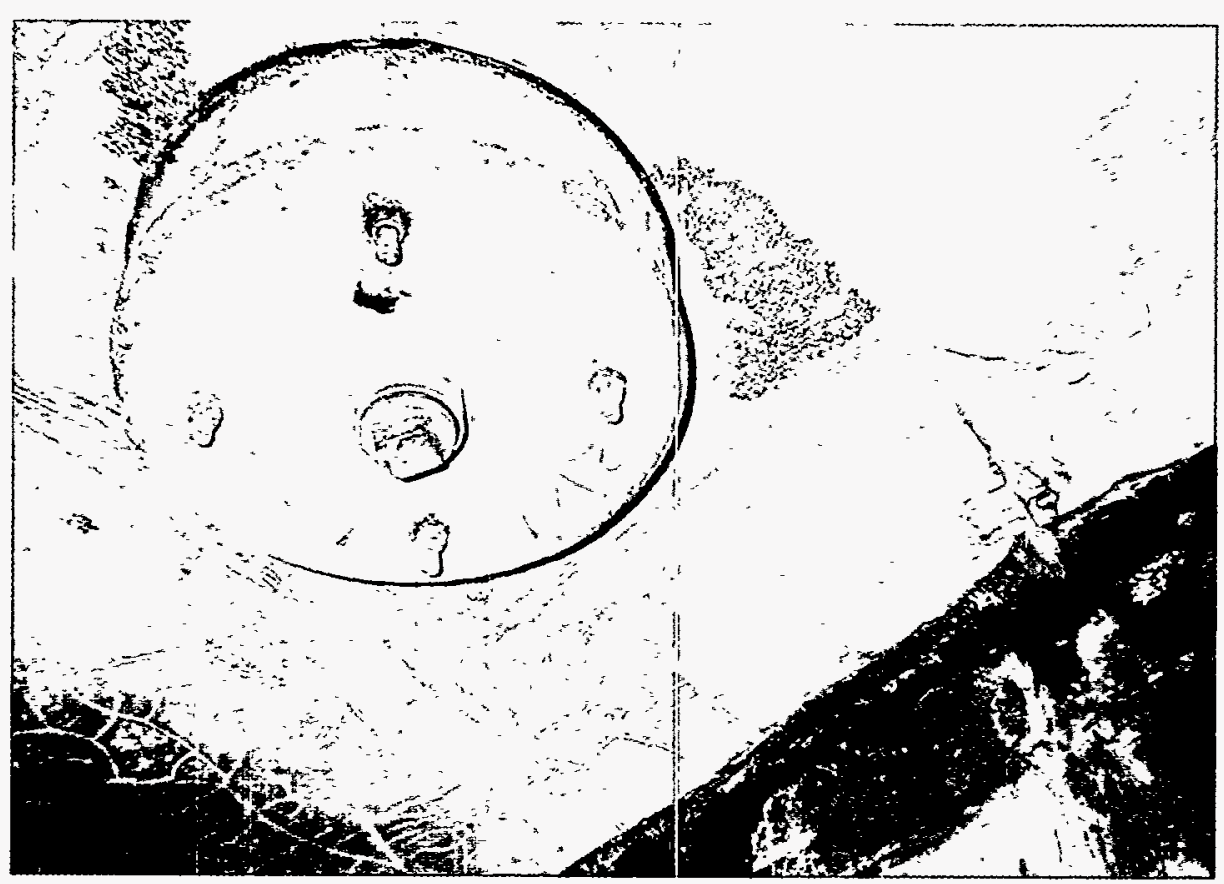

Metal Corrosion and Concrete Cracking at Tendon 12-V-1 (Typical) 
Plate 12 - Turkey Point Nuclear Power Plant Unit 3 containment Dome

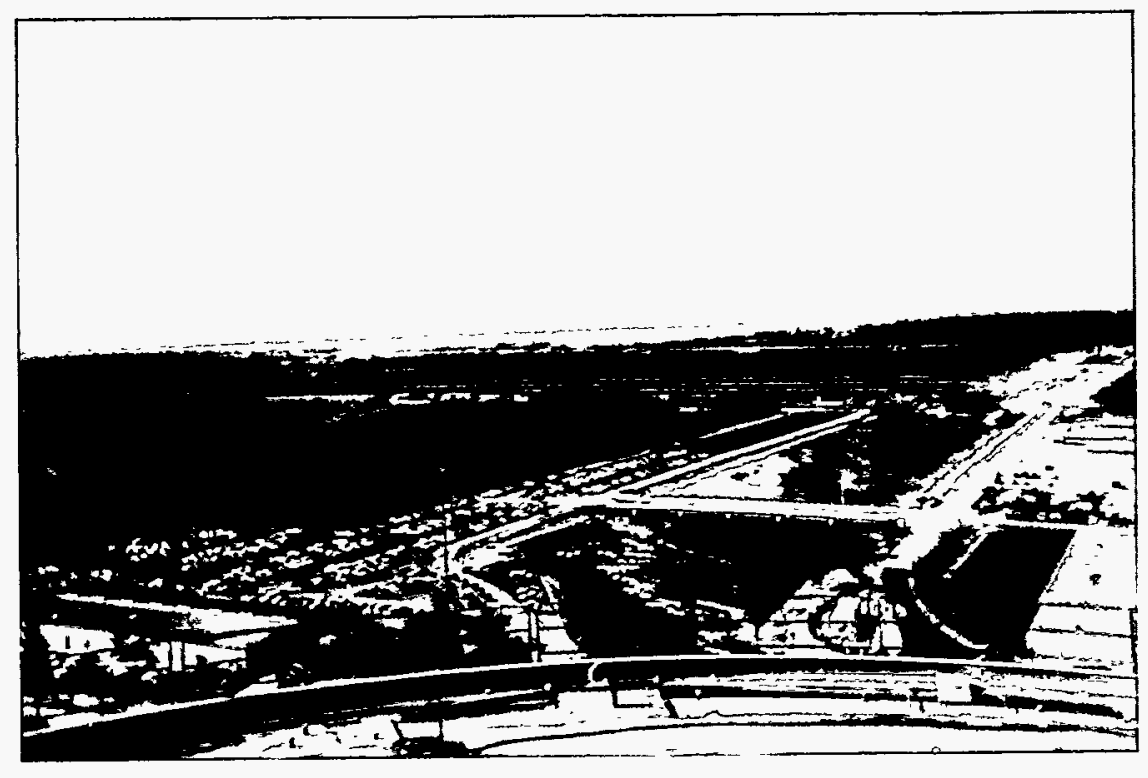

View of Site Cooling Water Discharge and Canal System Looking SW From Atop Unit 3 Containment Dome

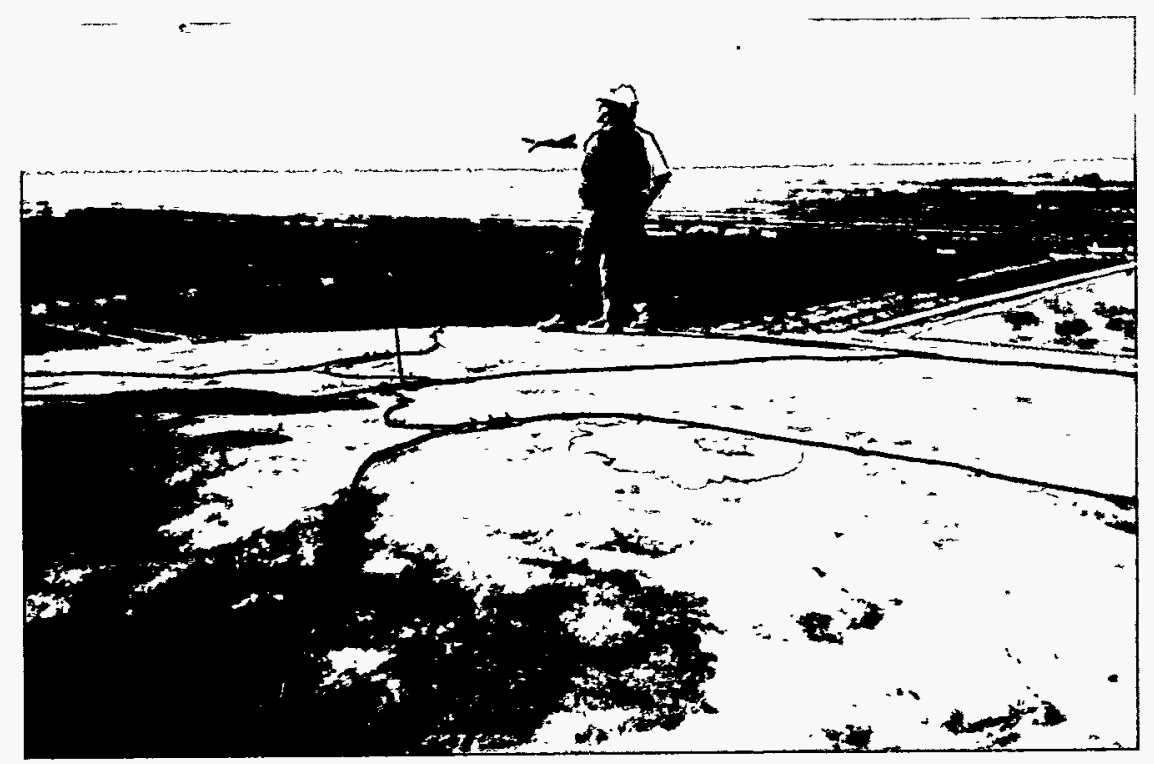

Peeling of Dome Coating Material (White Areas); Possible Cause of Water Drain Blockage 


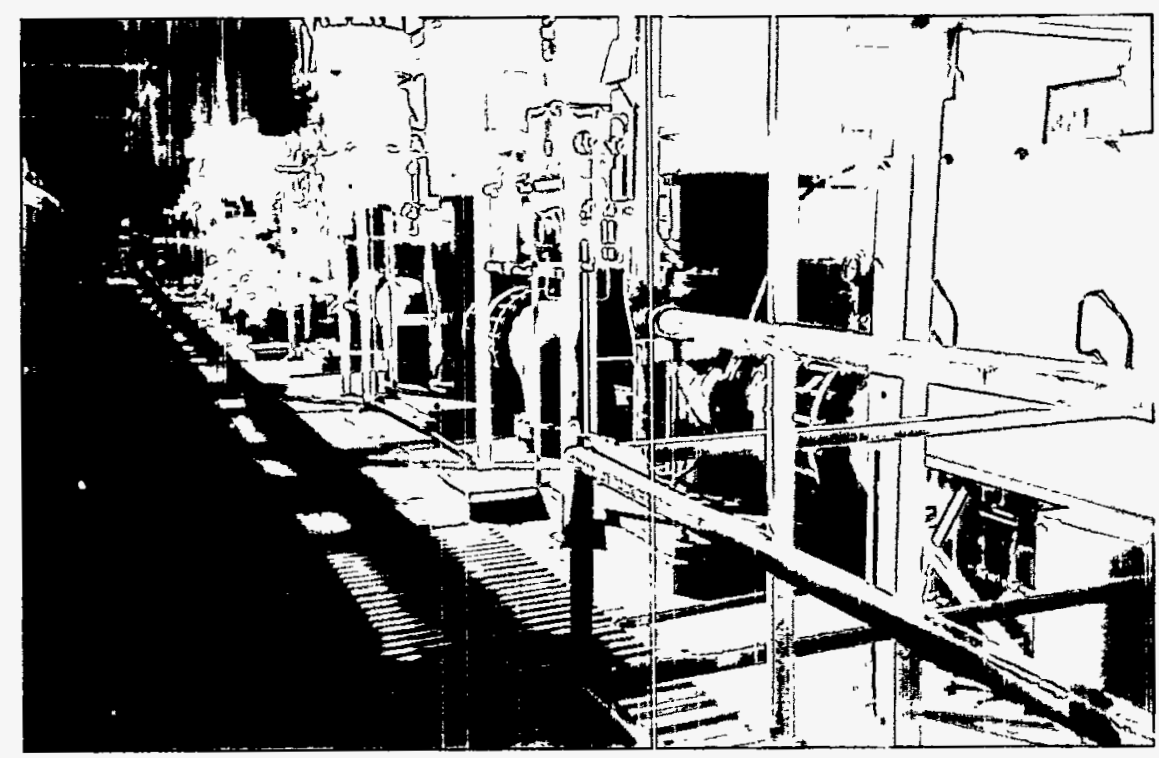

Circulating Water Pump Mounted on Top of Intake Structure;

Supporting Concrete Beams Have Deteriorated and Are Currently Being Strengthened

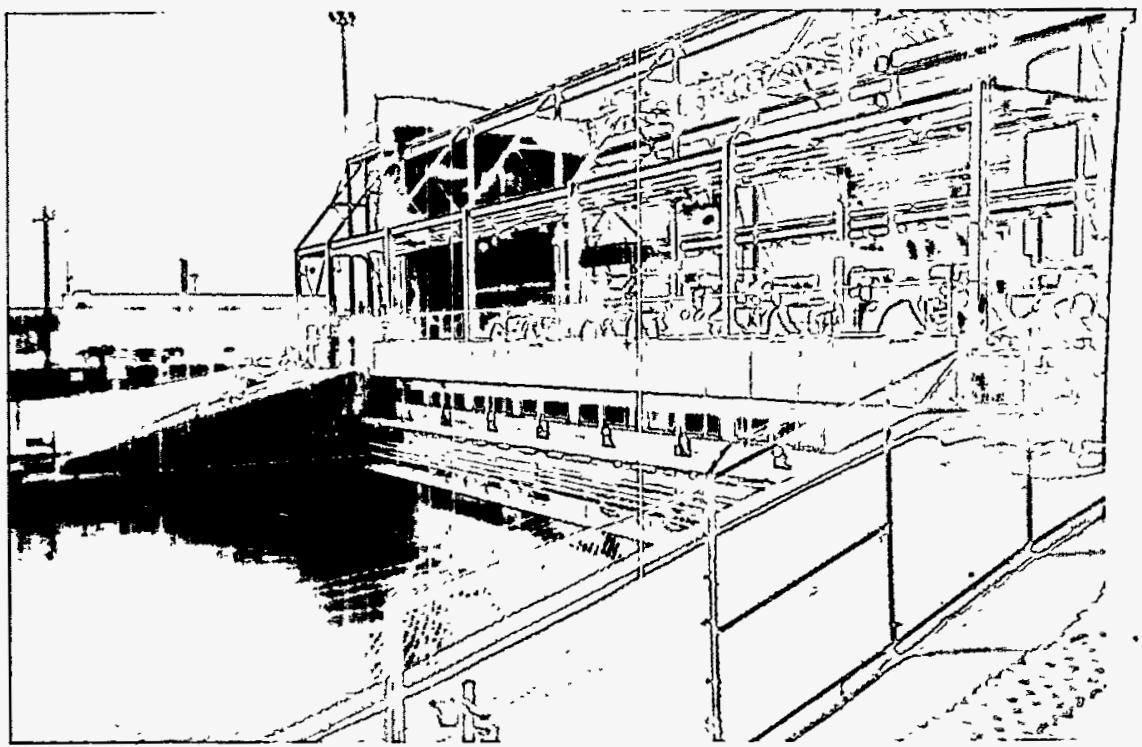

View of Cooling Water Inlet, From North Side, Looking SW 
Plate 14 - Turkey Point Nuclear Power Plant A- Unit 3 Spent Fuel Building;

B- Air Handling Room in Control Building

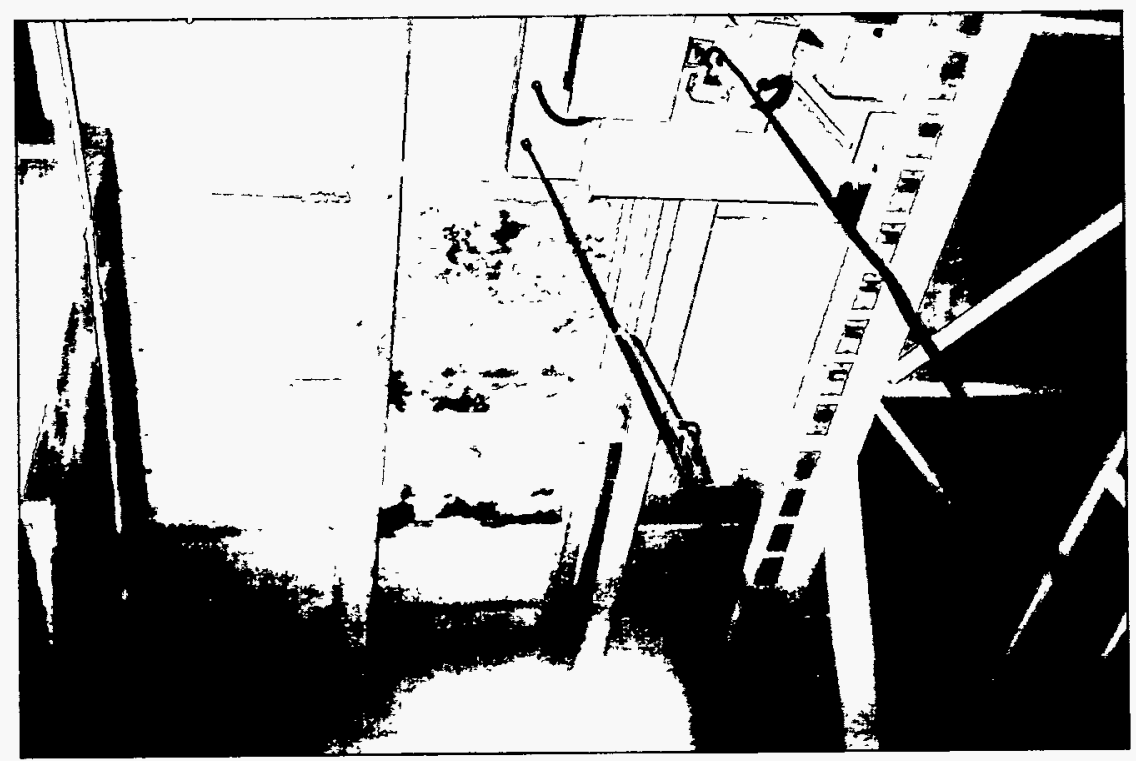

A - Approximately $3^{\prime} \times 6^{\prime}$ Area of Discoloration on Ceiling; Possible Water Leak From Roof

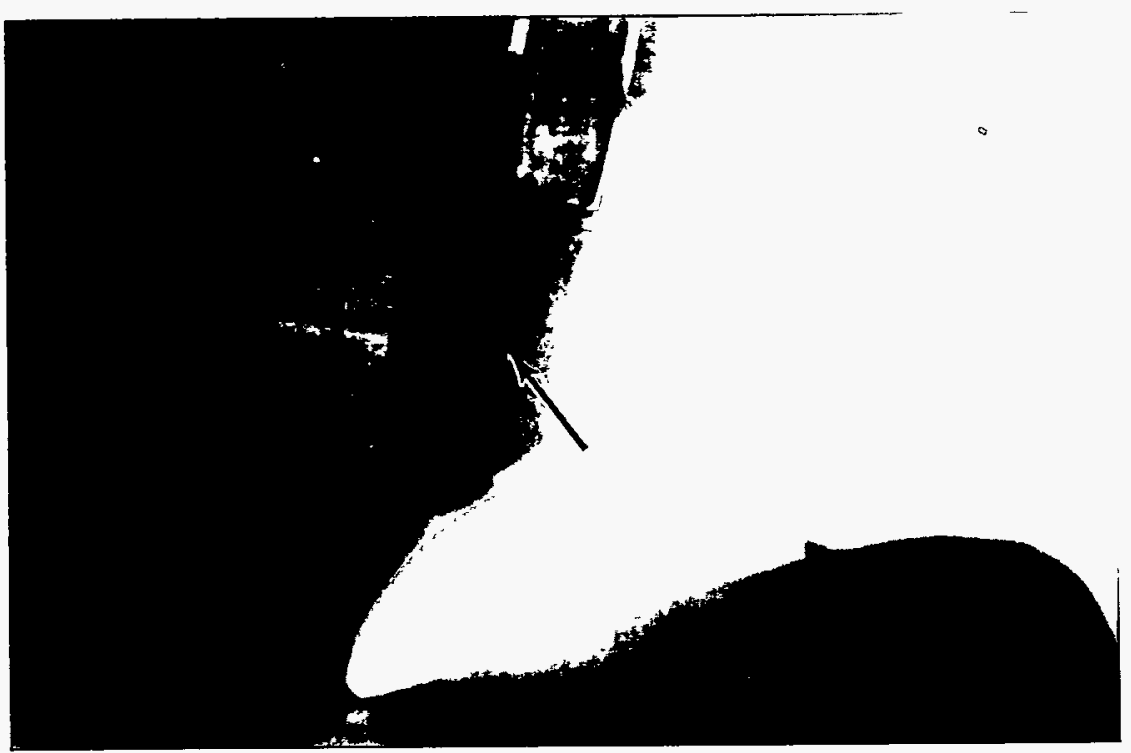

B - Gap Between Masonry Wall and Angle Support Installed at Ceiling as Part of Bullet in 80-11 Program (View Looking Up) 
Plate 15 - Turkey Point Nuclear Power Plant Unit 3 Condensate storage Tank

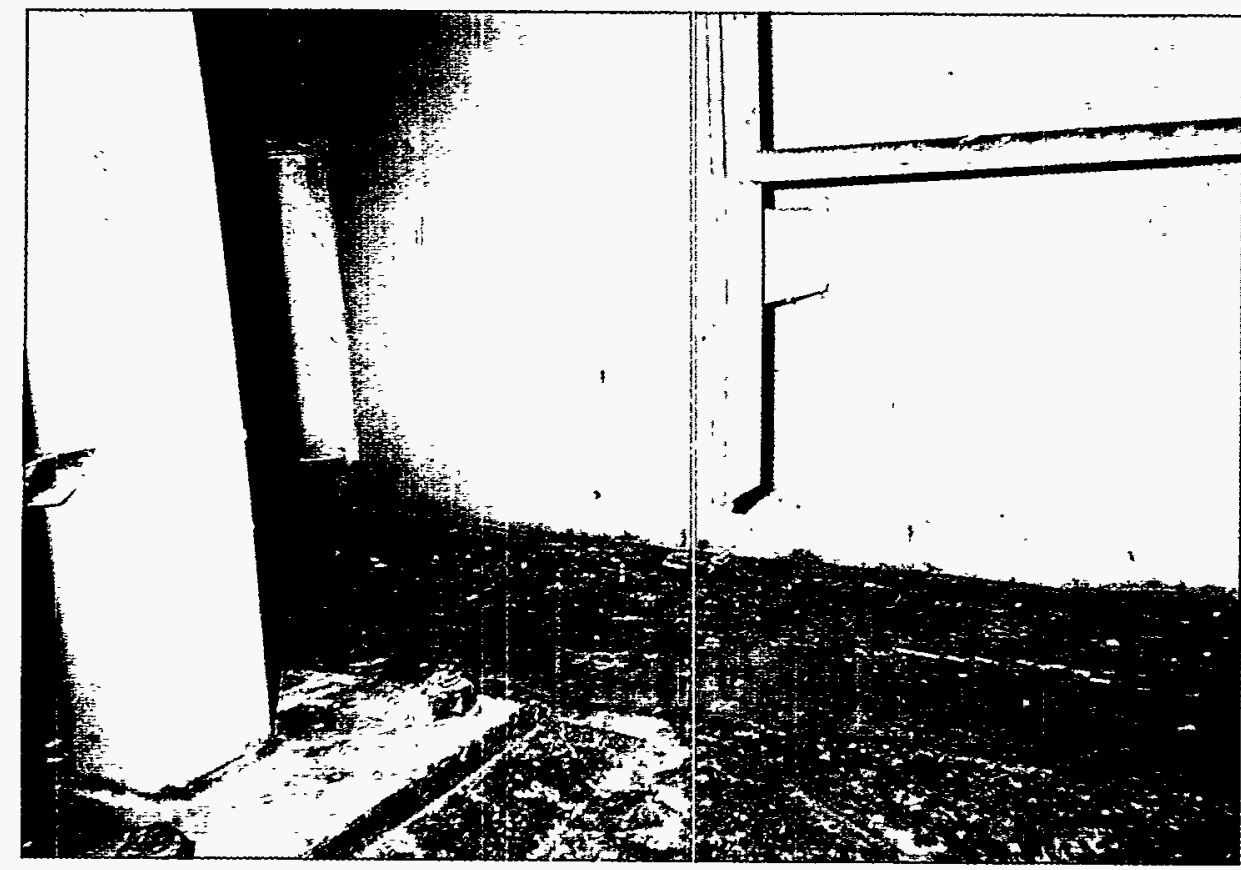

Deterioration of the Water Seal at

Base of Tank/Corrosion of Tank Bottom Plate

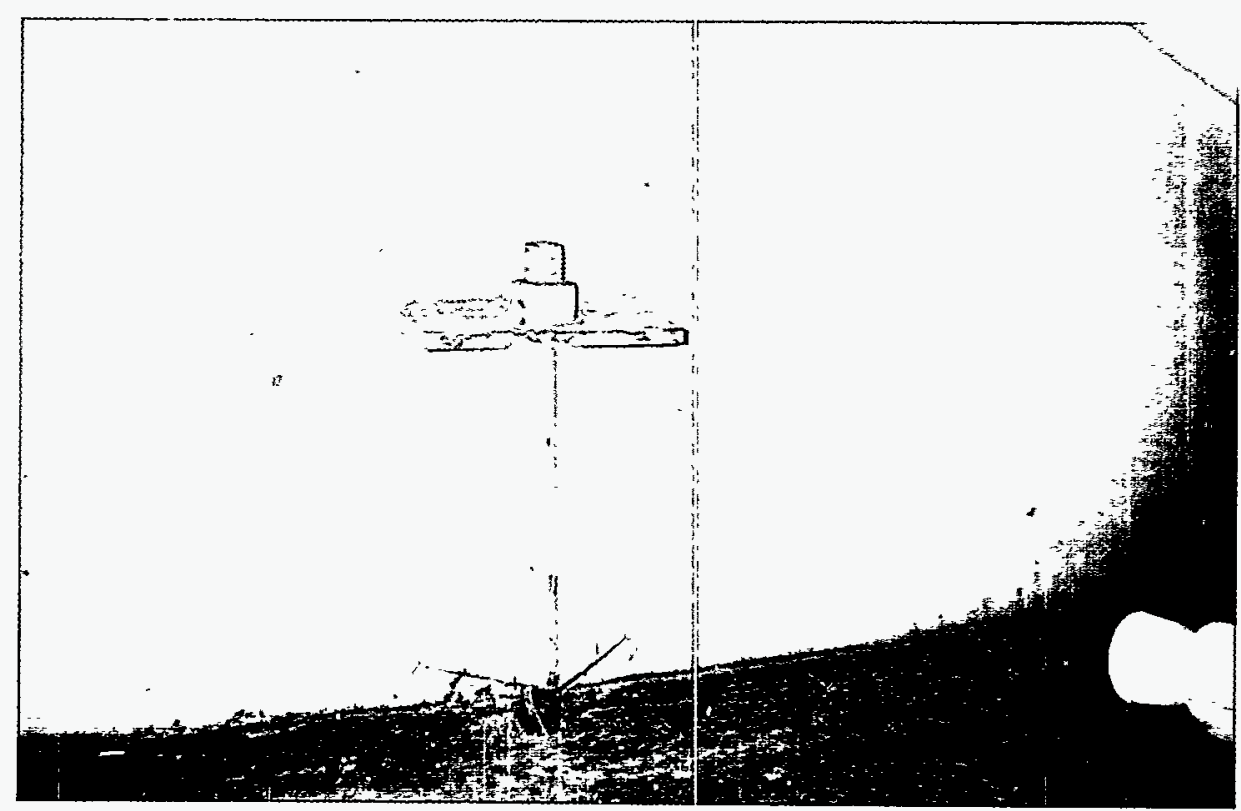

Typical Condition of Anchor Bolt Chairs 


\section{H.B. ROBINSON NUCLEAR PLANT UNIT 2}

\section{Walkdown Description}

April 14, 1992:

A formal presentation was made by Carolina Power and Light Compay (CP\&L) personnel. The major topics covered include design criteria, containment structure, support anchorages, spent fuel pool/racks, intake structure, masonry walls, ground water issues, buried piping, storage tanks, dam design/maintenance, civil/structural LERs and 10 CFR 50.59 evaluations, and plant safety procedures for natural phenomenon.

April 15, 1992:

In the morning the entire audit team conducted a walkdown inside the containment structure. The audit team began its walkdown by entering through the personnel hatch. The containment and internal structures from the operating floor down to the basemat area were examined.

At the operating deck level, a visual examination was made of the dome liner, containment spray ring, polar crane support and refueling pool. At lower levels, the audit team examined the R.C. pump bay, RPV head storage area, shield wall, equipment hatch, piping supports, piping penetrations, cable tray and conduit supports, HVAC, and basemat. These areas were examined for signs of degradation and conditions which may warrant monitoring or remedial action. The vertical portion of the containment liner was not visible because of a layer of rigid insulation attached to the inside face of the liner.

In the afternoon the entire audit team examined the nearby Lake Robinson Dam. This dam, which is located at the southern end of Lake Robinson, maintains the proper water surface elevation normally at elevation 220 feet. The water contained in this lake is used by the Robinson Nuclear Plant Unit 2 and the adjacent coalfired plant, Unit 1. The earth dam is approximately 4,000 feet long and has a maximum height of 55 feet. The water level is controlled by a gated concrete overflow spillway. observations were made of the gates, spillway, and the entire length of the earth dam.

During the remainder of the afternoon, the audit team was split into two teams which followed two separate routes to perform additional walkdowns of other structures. The two routes covered the same structures and components but followed different paths.

The structures examined are the reactor auxiliary building, turbine building, exterior of the containment, and water storage tanks. Walkdowns within these areas include waste evaporator area, 
boric acid batch room, safeguard area, control room, diesel generator rooms, safety injection pump room, emergency bus rooms, battery rooms, spent fuel pool heat exchanger area, RHR pump area, seismic monitor room, refueling water storage tank, and primary water storage tank. Structural components reviewed in these areas include concrete floors, walls, ceilings, and roofs; building structural steel; conduit/supports; cable tray/supports; piping support anchorages; seismic gaps between buildings; equipment supports; tanks; and masonry walls.

April 16, 1992:

In the morning the audit team examined the intake structure along the shore of Lake Robinson. The areas examined were the lower level elevation 218 feet (lower level below grade) and pump area elevation 226 feet (grade level). At the lower elevation, the concrete floor, walls, and ceiling were examined as well as the service water piping and supports. At the grade level, the concrete floor and exterior walls were examined. In addition, the service water - piping, piping supports, and pump anchorage were examined.

Later in the day, the audit team reviewed the 10 CFR 50.59 program at Robinson Unit 2 as it relates to civil/structural modifications/evaluations. The "Plant operating Manual - Plant Program," PLP-032, Rev. 4 was provided to the audit team for review. Appendix I of this manual contains the CP\&I 10 CFR 50.59 Program Manual, Rev. 2. This program manual describes the items requiring 10 CFR 50.59 evaluation, the responsibilities of the personnel performing the safety reviews, procedures for conducting the safety reviews, guidelines for completing the forms, and training/qualification guidelines.

From a list of specific 10 CFR 50.59 packages related to civil/structural items, the audit team selected five packages to review. These covered 50.59 packages for which only evaluations were required and packages which also contained modifications to plant structures/components.

\section{Results/Observations}

\section{Inside containment}

1. Discoloration of the vertical portion of the containment liner at an insulation joint was observed. The vertical portion of the liner was not generally visible because of a layer of rigid insulation attached to the inside face of the liner. Thus, it was not possible to determine if the discoloration was due to corrosion, degradation of the liner paint/coating or some other cause.

2. There were a number of locations of liner bulging radially inwards. Extent of deformation was difficult to identify due to insulation covering the liner. CP\&L discovered this during 
Post-structural Integrity Test inspection in May 1974. Condition was visually inspected and mapped. Stress analysis was performed to verify structural integrity of the liner. Surveillance program was established using strain gages to observe long-term changes.

3. Extensive corrosion of three valves and piping associated with the component cooling water system was observed. The tag numbers on these valves are CC-724B, CC-725B, and CC-726B (Plate 16).

4. Corrosion of a support to the main feedwater line $A$ was identified. The corrosion was located at the top of this vertical support which was located at the 2 nd level inside containment (Plate 16).

5. In some areas of the basemat, the coating on the concrete surface was peeling and cracking severely (Plate 17). The concern is that any water accumulation could enter into the concrete floor and potentially reach the liner in the basemat which would cause corrosion to occur.

Exterior containment

1. Some abandoned holes on the outside of the concrete containment were identified. These, as well as any other abandoned holes, should be filled.

2. In the pipe alley, two baseplates were identified which bridge the 2" seismic gap between the reactor auxiliary building (RAB) elev. 226 ft. floor slab and containment base slab. In addition, at the support to the WD line, the basemat has a 6 to 8 foot long crack up to 1/8" wide.

Reactor Auxiliary Building (RAB)

1. Signs of past water infiltration at the intersection of the roof to wall junction were observed from the stairs leading to the waste evaporator area (level 3). A tear in the roofing membrane was noted at the junction of the roof and wall when viewed from outside in the same area (Plate 18).

2. Spalling of concrete in the ceiling was identified when viewed from level 2. The ceiling location corresponds to the floor of the waste evaporator.

3. Various anchorage deficiencies were observed at different locations. Examples are insufficient anchor thread engagement in nuts for the neutralizer filter support, missing nuts and insufficient thread engagement in other nuts for C.V. vent panel, missing washer on anchor for electrical cabinet in charging pump room, and missing washer and anchor out of plumb for conduit support in elev. $226 \mathrm{ft}$. hallway south of diesel generator room. 
4. A number of water stains were identified on the bottom of cable trays in the safeguards room.

5. A number of concrete cracks were identified in various locations including emergency diesel generator room B (size hard to determine due to coating) and concrete wall adjacent to C.V. vent panel on level 2. These type of cracks should be identified, monitored, evaluated if significant, and repaired if necessary.

Intake structure

1. Cracks at intersection of the concrete walls when viewed at grade level elev. 226 feet (Plate 19).

2. Severe pitting on the service water line was observed on many sections of pipe (Plate 20).

3. Some service water hangers showed signs of corrosion and the rod connection detail to channel section should be checked.

4. The friction clamp on the South service water header was found to be in a degraded condition.

5. The foundation bolts of the strainer were observed to be degraded.

Water storage Tanks

1. Corrosion of nuts at beam seats were observed at the refueling water storage tank (RWST) and the primary water storage tank (PWST) (Plate 21).

Lake Robinson Dam

1. A substantial amount of water was leaking around the side of the gates onto the steel beams that support the gates. This occurred at two of four steel beam support structures to the gate. If this condition is not corrected then the steel will corrode and deteriorate quickly.

2. Spalled concrete was identified beneath two beam seats that support the walkway over the dam gates.

3. Spalled concrete or holes were observed in the dam at the water line.

Other structures

1. Initiation of corrosion was observed underneath structural steel located in the Seismic Category I area of the turbine building near column F12 (looking up from lowest level) (Plate 21). 
2. A significant bulge in concrete wall of the CVCs hold up tank structure was observed.

3. There is no ongoing program for the identification and subsequent repair of cracks in seismic Category I masonry walls. This is important since the seismic calculations assumed that the masonry walls were unreinforced and thus relied on the full bending capability of the masonry walls (without cracks). 
Plate 16 - H.B. Robinson Nuclear Plant, Unit 2 Inside containment - Corrosion

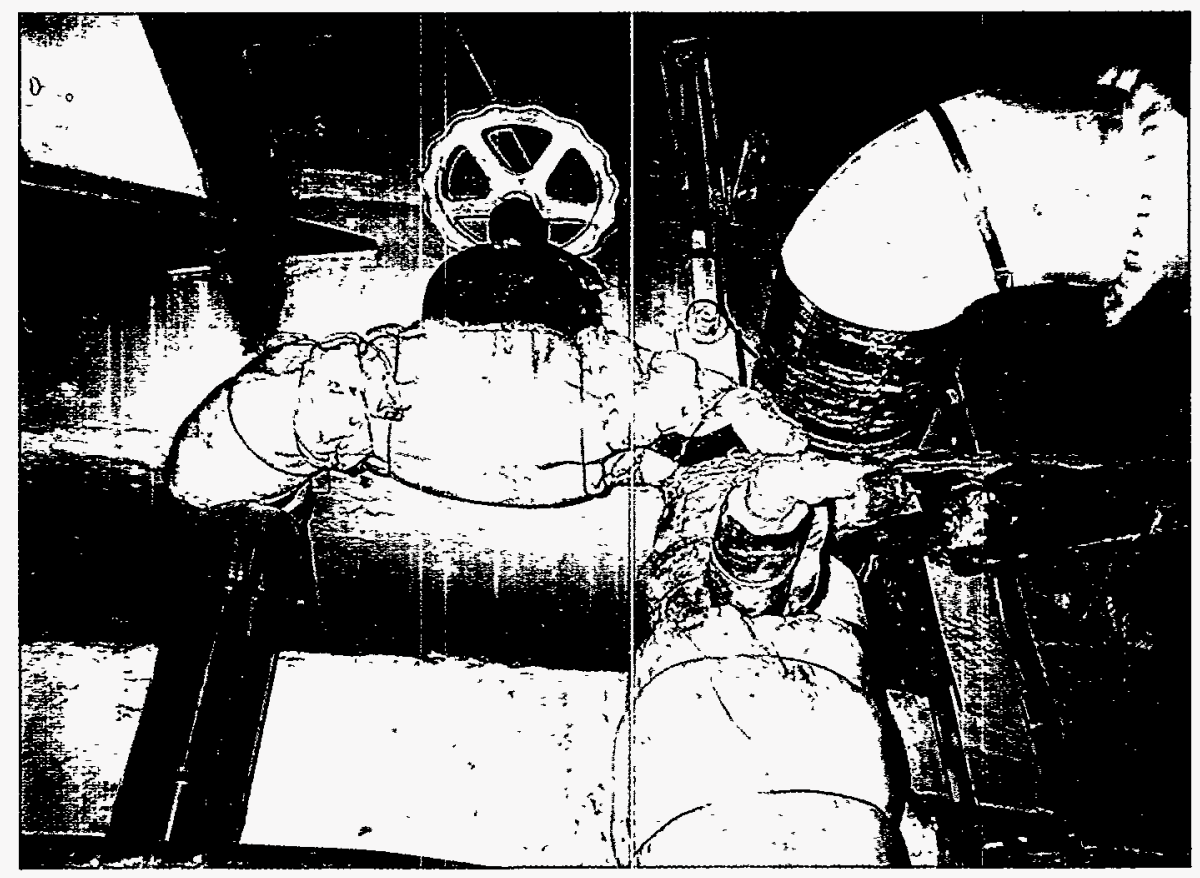

Component Cooling Water Valve and Piping

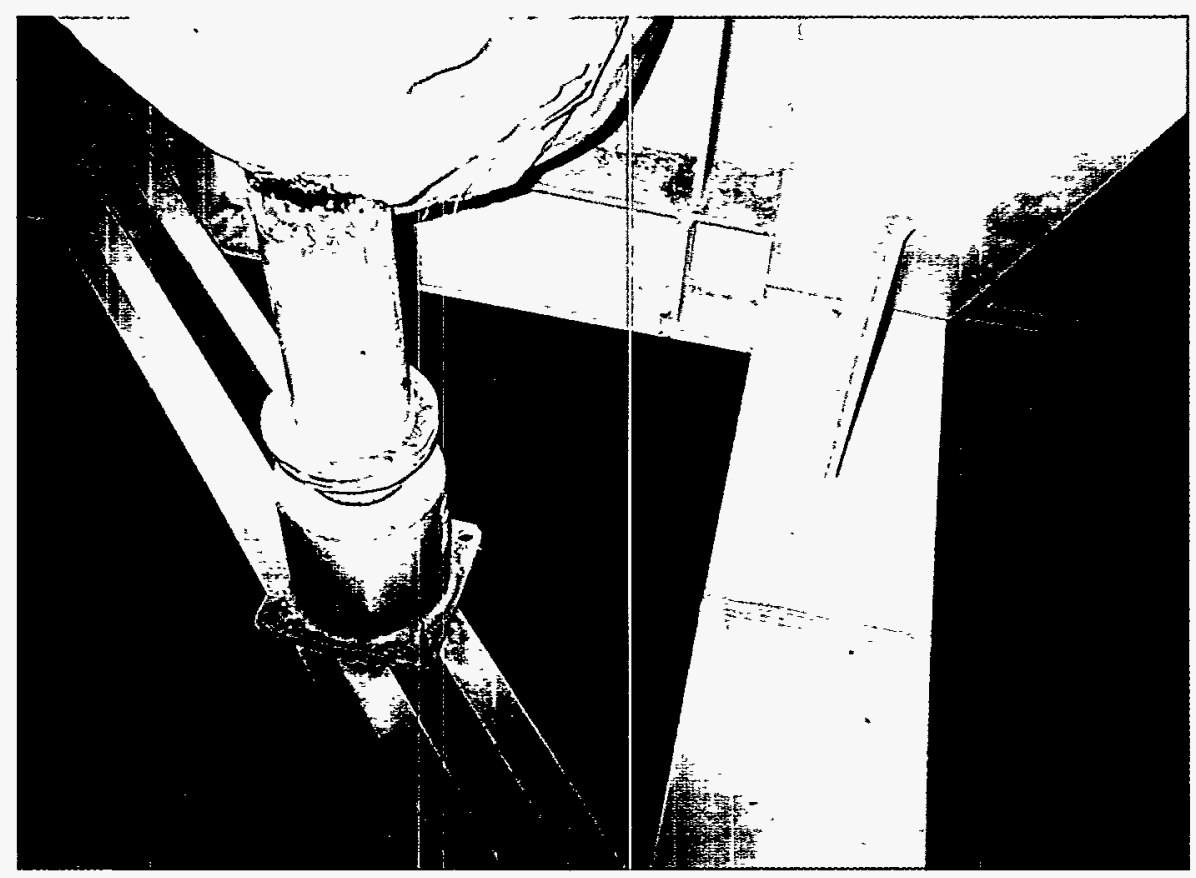

Top of Support to the Main Feed Line A 
Plate 17 - H.B. Robinson Nuclear Plant, Unit 2

Inside Containment - Peeling and Cracking of Coating on Basemat
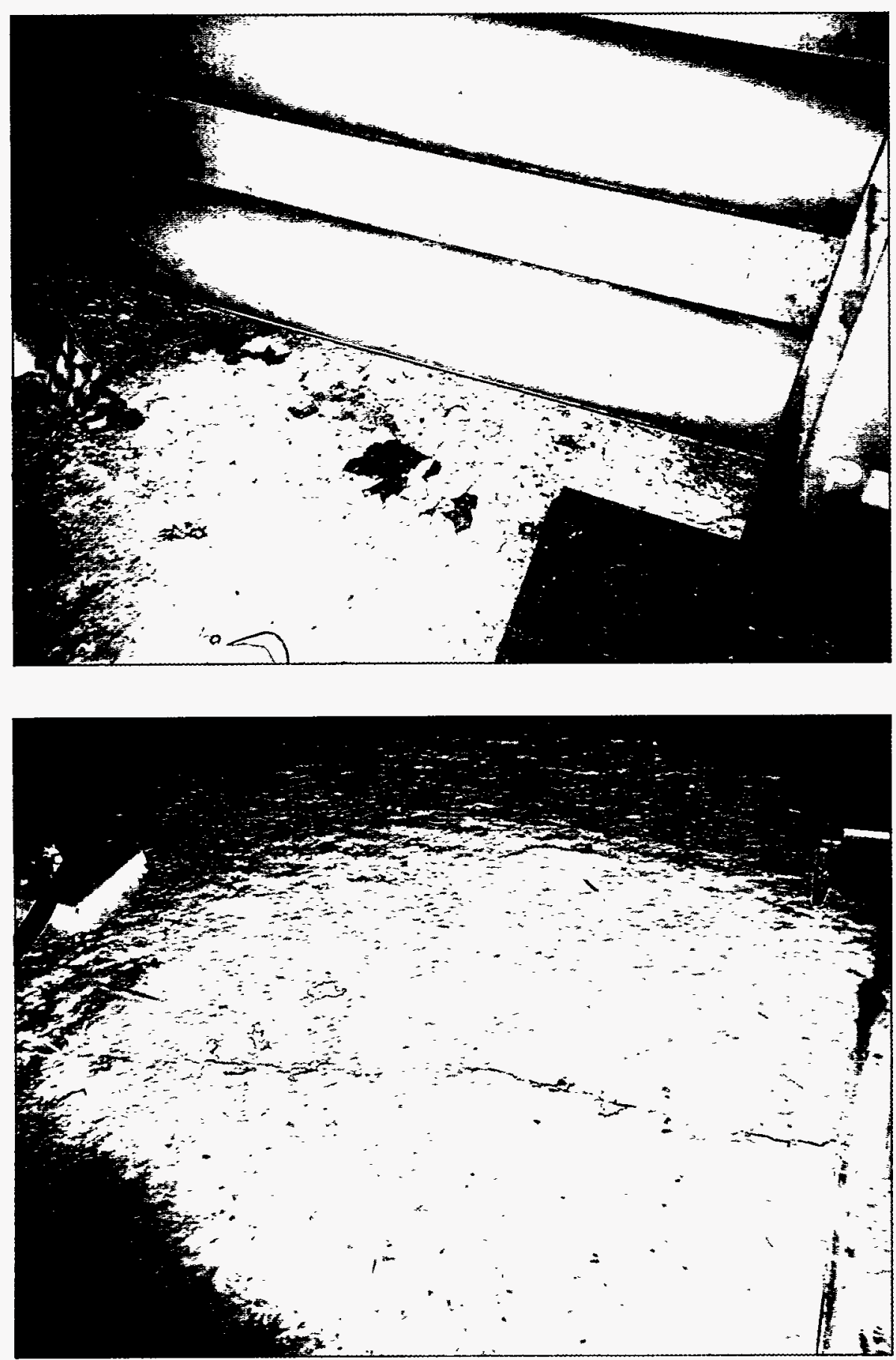


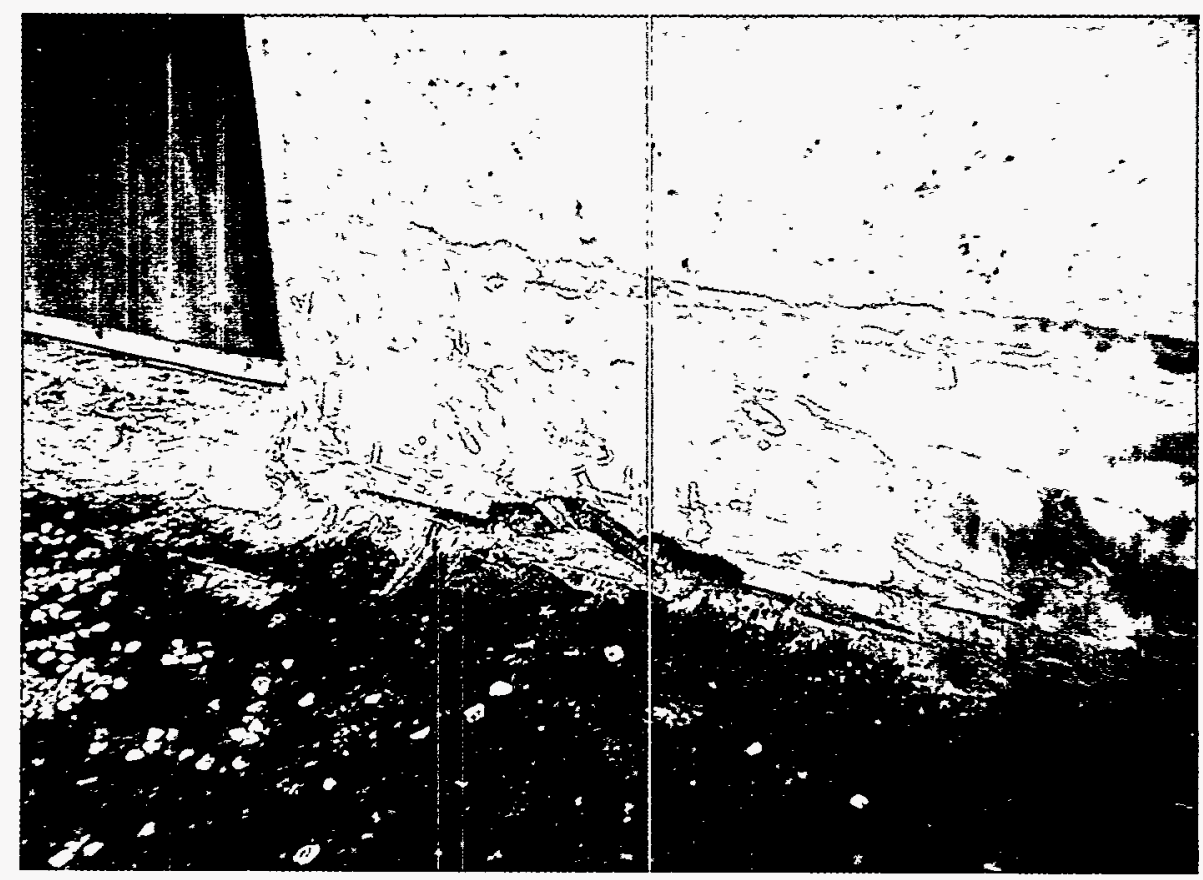

A Tear in Roofing Membrane

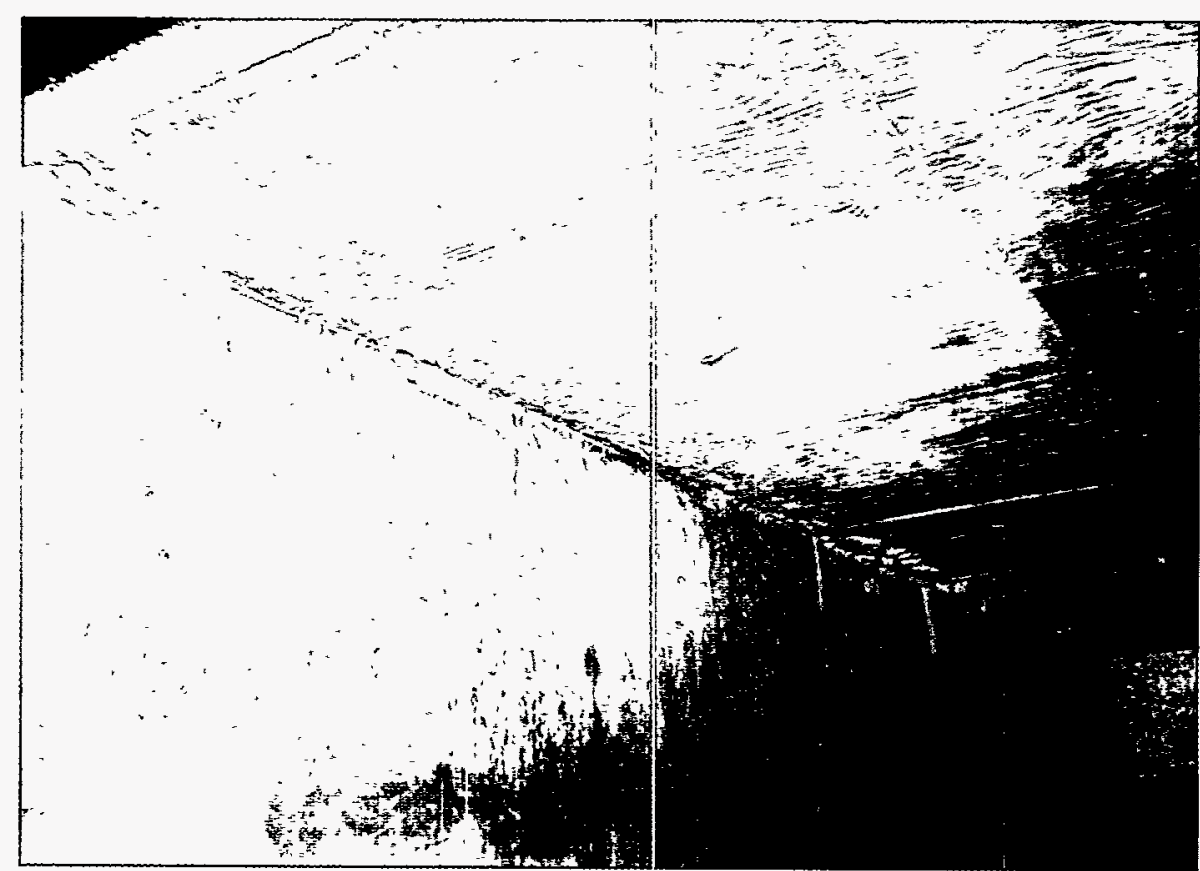

Indication of Water Infiltration at

Intersection of Wall and Roof 
Plate 19 - H.B. Robinson Nuclear Plant, Unit 2 Intake structure

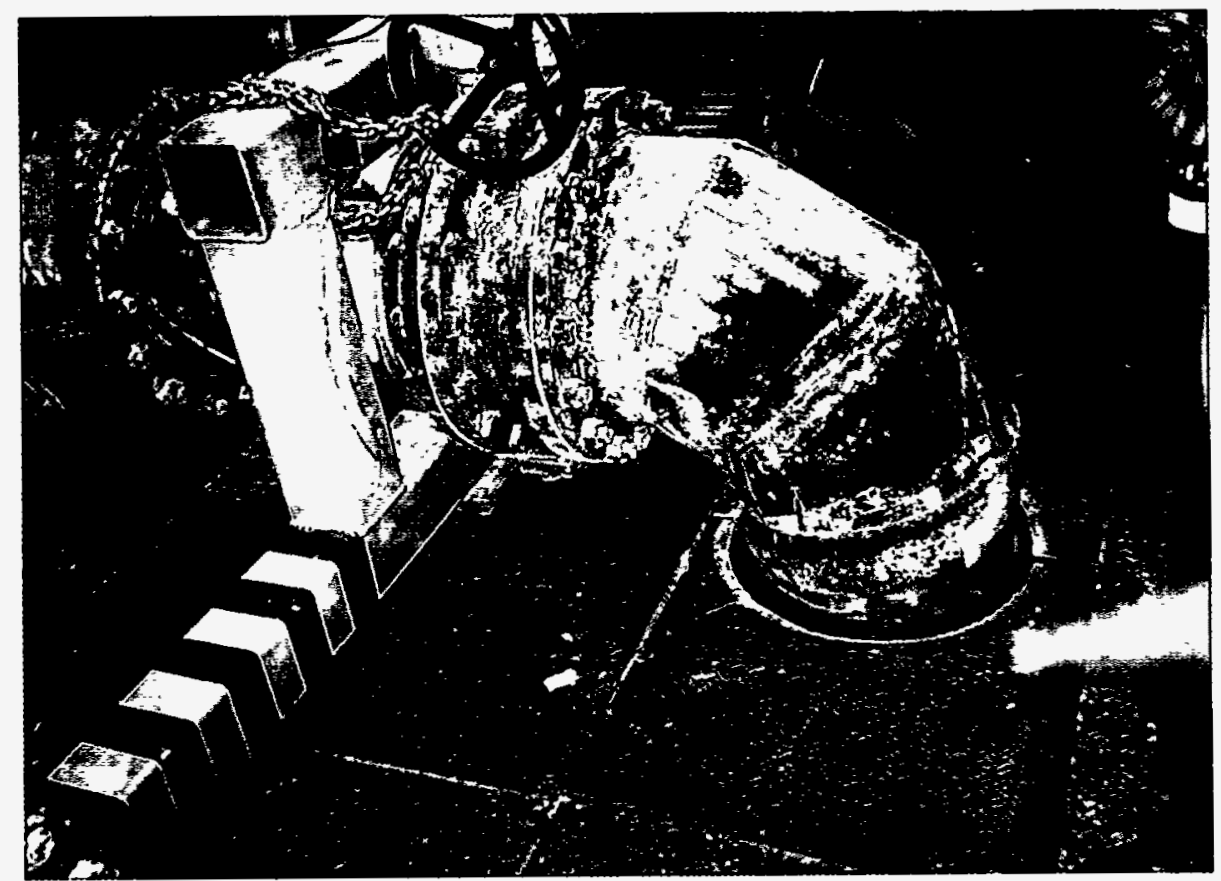

Corrosion and Degradation of Service Water Line - Above Grade

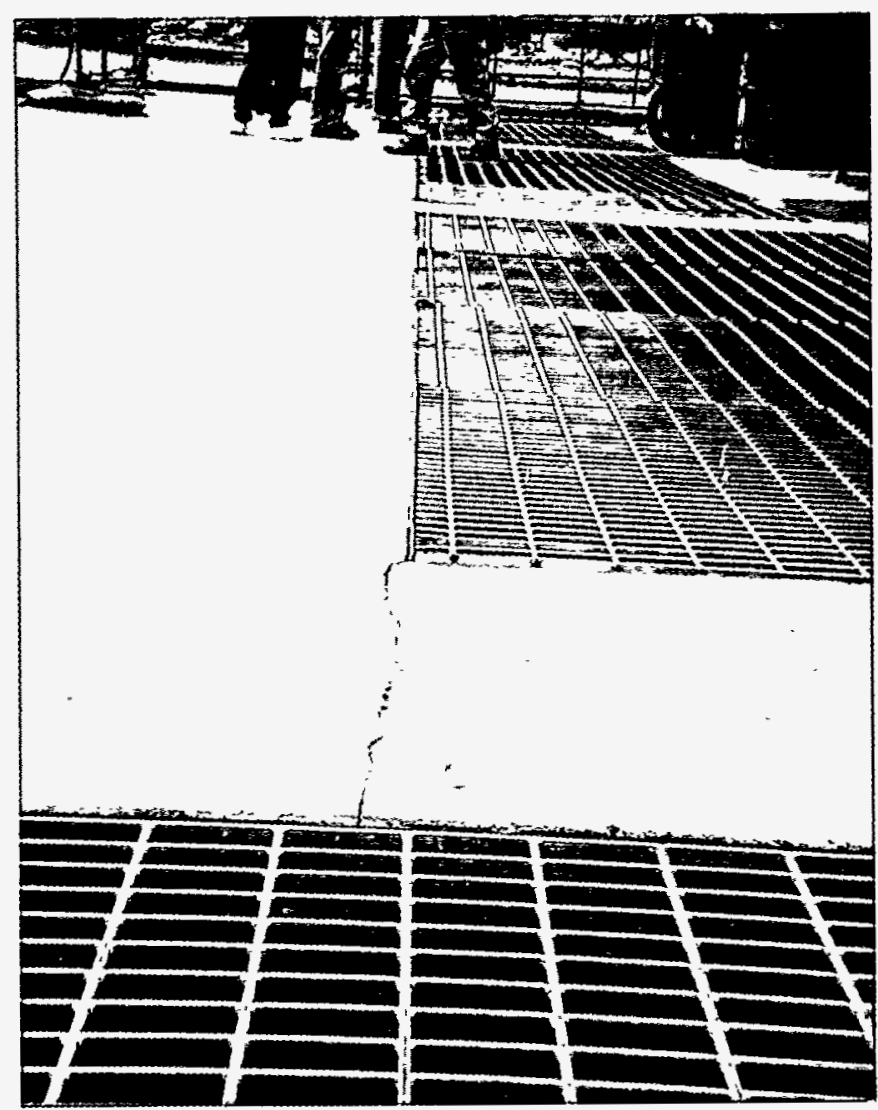

Cracks at Intersection of Concrete Walls 
Plate 20 - H.B. Robinson Nuclear Plant, Unit 2

Intake Structure - Severe Pitting of

Service Water Line, Below Grade
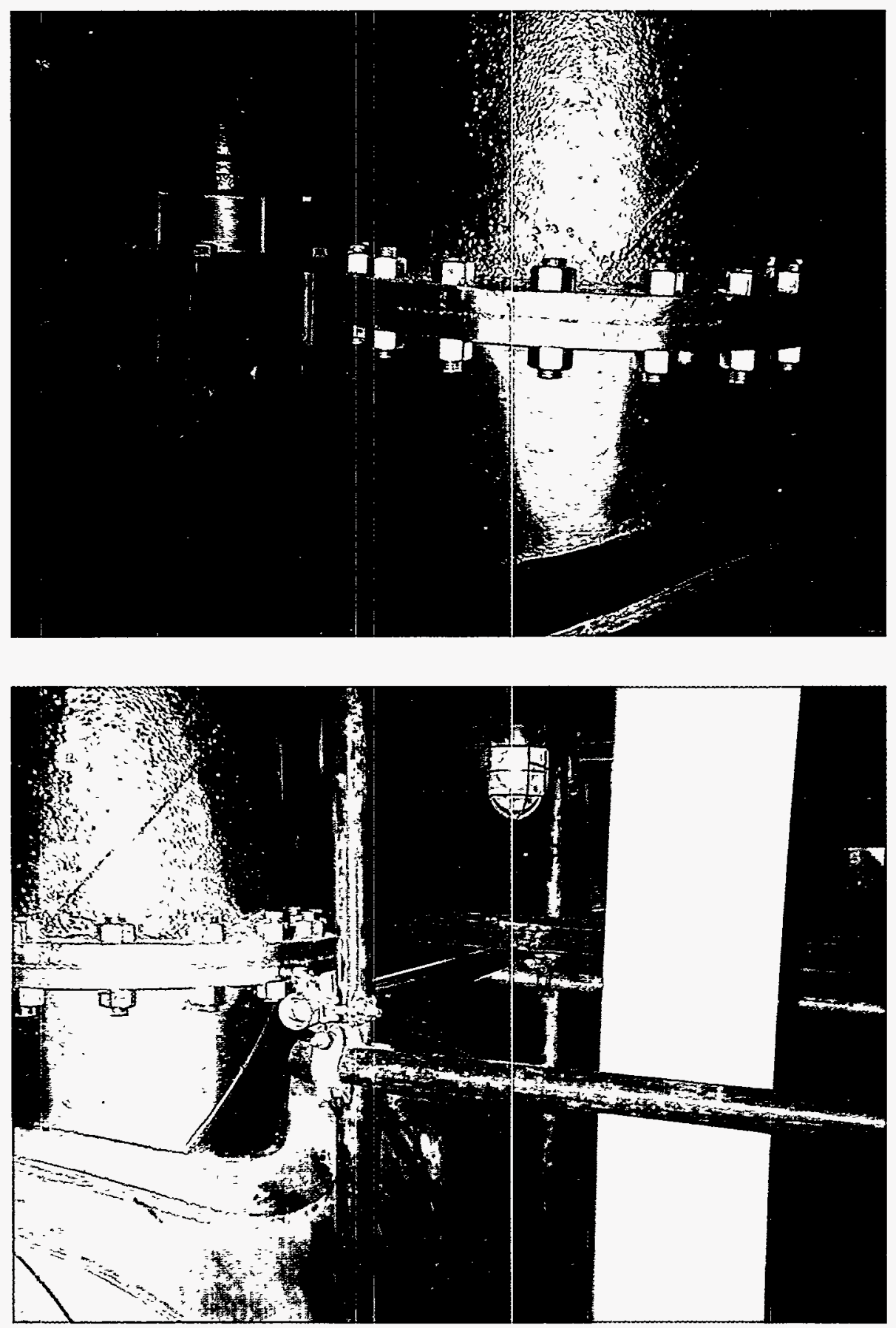
Plate 21 - H.B. Robinson Nuclear Plant, Unit 2 A- Seismic Class 1 Area of Turbine Building; B- Beam Seat of Primary Water storage Tank

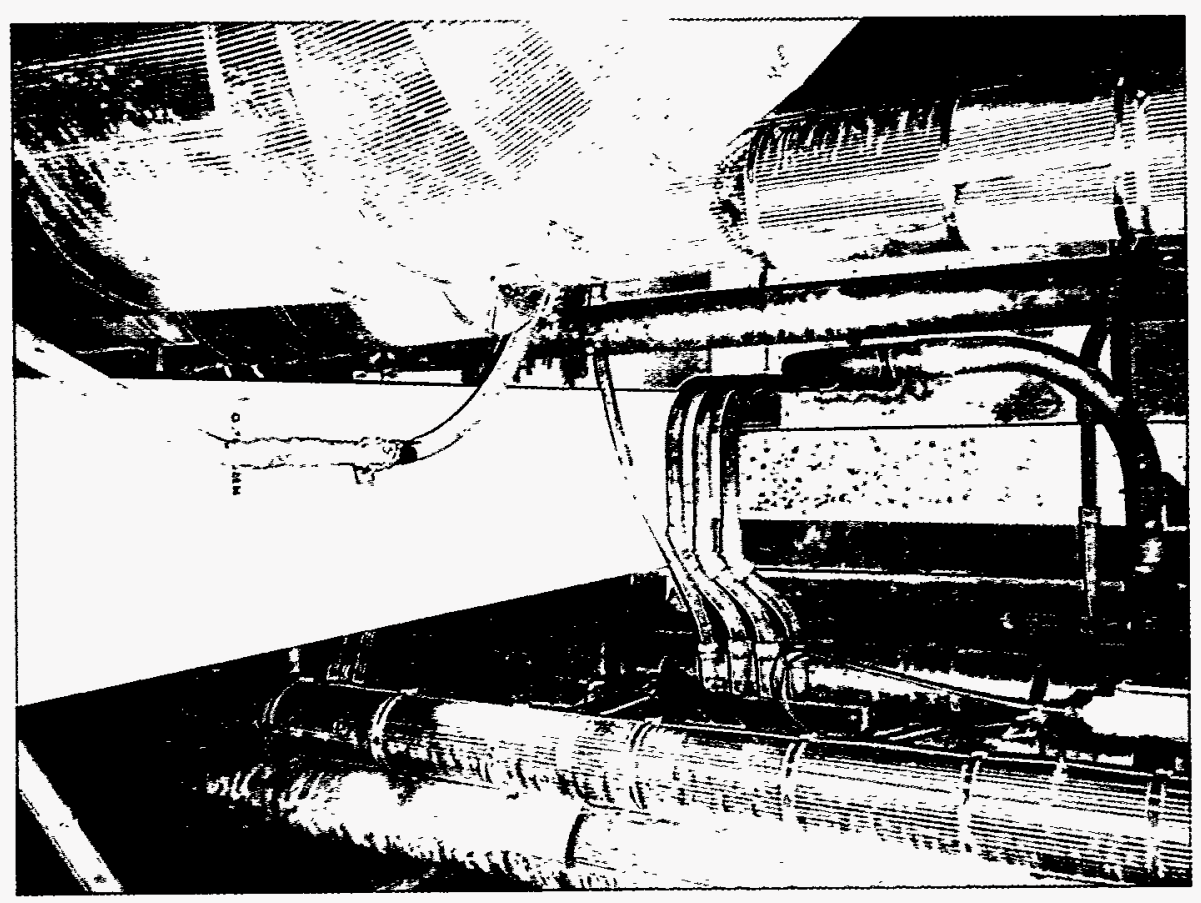

A - Corroded Structural Steel in Seismic Class 1 Area

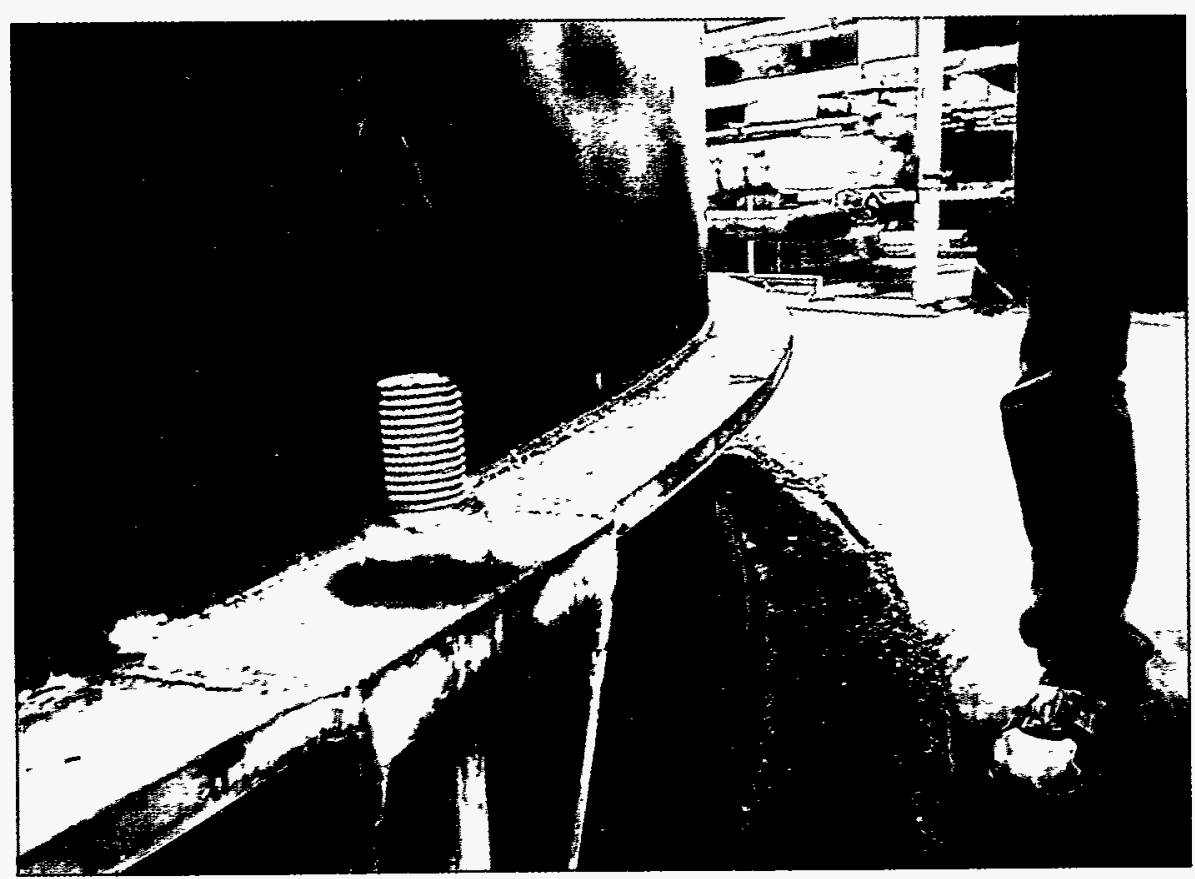

B - Corroded Nut at Beam Seat 



\section{BEAVER VALLEY POWER STATION UNIT 1}

Walkdown Description

June 16, 1992:

A formal presentation was made by Duquesne Light Company (DLCo) personnel. The major topics covered include design criteria, containment structure, support anchorages, spent fuel pool/racks, intake structure, masonry walls, ground water issues, buried piping, storage tanks, civil/structural LERs and 10 CFR 50.59 evaluations, and plant safety procedures for natural phenomena.

June 17, 1992:

The audit team remained together throughout the plant walkdown activities. The first area visited was the intake structure, which is enclosed by a steel frame superstructure over the traveling screens and pump cubicles. The specific areas examined include interior concrete walls, floors, and ceilings; pump cubicles A, B, $C$, and $D ;$ and the exterior concrete walls. There was no immediate access for examining concrete at the water line. Since this required plant maintenance assistance, it was arranged for the following morning.

Next, the team reviewed the exterior of- Category I structures and storage tanks, including the containment; the cable vault and main steam valve house; the coolant recovery structure; the refueling water storage tank; the safeguards area; the diesel generator building; the steam generator drain tank; the primary auxiliary building; the fuel building; the turbine building; and the concrete enclosure for the demineralized water storage tank (no access to confined area).

Following completion of the outside inspections, the team examined the interior of the primary auxiliary building and the fuel building on elevations $722^{\prime}-6^{\prime \prime}, 735^{\prime}-6^{\prime \prime}, 752^{\prime}-6^{\prime \prime}$, and $768^{\prime}$. Structural components reviewed included concrete floors, walls, and ceilings; building structural steel; conduit/supports; cable tray/ supports; pipe supports; equipment supports; support anchorages; seismic gaps between buildings; tanks; masonry walls; and the spent fuel pool and fuel transfer canal.

June 18, 1992:

The walkdown began this day with the interior of the diesel generator building. The concrete walls, floors, and ceilings; the diesel generator supports; attachments to concrete; and general features were examined.

Next, the team returned to the intake structure to assess the condition below the operating floor; it is accessible only through 
normally closed manholes. One team member accompanied the DLCo representative into the $c$ bay pit to check for degradation of concrete and steel.

Following this, the team examined the control room, primarily focusing on masonry walls in the vicinity of safety-related electrical cabinets and control parels.

The remainder of the walkdown encompassed the interior of the service building, the cable vault structure, and the safeguards building. The service building inspection included the switchgear rooms, the process rack area, and the air conditioning room on elevation 713'- 6", the cable mezzanine on elevation $725^{\prime}-6^{\prime \prime}$; and elevation $735^{\prime}$.

The cable vault structure review included the west cable vault, the auxiliary feedwater pump room, the main steam room, and motor control center room, and other areas on elevations 722', 735', 751', 756' and 776'. The safeguards building review included the hydrogen recombiner room, the recirculation spray pump room, the charging line, the quench spray line, the river water line, containment piping penetrations, and other areas on elevations $722^{\prime}$ and $747^{\prime}$.

Structural components examined in these areas include concrete floors, walls, ceilings, and roofs; building structural steel; conduit/supports; cable tray/supports; piping support anchorages; seismic gaps between buildings; equipment supports; tanks; and masonry walls. This concluded the walkdown activities.

In the late afternoon, the audit team reviewed several LER and 10 CFR 50.59 packages related to civil/structural items. These were either selected from a list provided by DLCo during their presentation or were provided by DLCo in response to specific questions by the audit team.

\section{Results/Observations}

containment

1. Concrete patches over construction related holes are deteriorating and falling out. This gives the appearance that small chunks of concrete are spalling (Plate 22).

2. Based on the Containment Inspection Reports conducted prior to the ILRTs, gouges, anchor holes, missing concrete chunks, and some cracks in the exterior concrete surface were also noted. In addition, rusted areas and peeled paint in several locations in the interior steel liner were identified.

3. A few instances of liner bulging were previously identified. DLCo stated that these were subsequently monitored to ensure that the deformations were not growing. 
4. Corrosion of the containment penetration for the component cooling line was observed from the safeguards structure at elevation 722 ft (Plate 23).

Intake structure

1. Concrete cracks in the ceilings of the pump cubicles were identified. Many of the cracks were located near the access panels used for pump maintenance. Crack sizes up to approximately .075 inches were observed (Plate 24).

2. Corrosion of the horizontal structural steel supports for the raw water piping was observed in bay "C" pit (below grade). This may be due to the water that is trapped in the horizontal structural shapes used to support the pipes.

3. In some of the pump cubicles, grout degradation and baseplate corrosion were identified in small diameter piping supports (Plate 24). In addition, conduit supports on the concrete wall had missing washers, untorqued anchors, one missing anchor, gaps with the wall and bent members.

4. Three vertical cracks were observed on the exterior concrete wall on the South side. The cracks were approximately .02 inches wide and 10 feet long.

Diesel Generator Building

1. Long cracks running in the ceiling of both diesel generator rooms were observed. The cracks run the entire width of the room from the East wall to the West wall.

2. The exterior South wall has a region of concrete which has spalled off to a depth of $1 / 2$ inch, exposing the steel reinforcement. The reinforcement shows signs of corrosion (Plate 25).

Primary Auxiliary Building

1. A structural steel angle, initially installed under DLCo's IE Bulletin 80-11 program to restrain the bottom edge of a masonry wall, was found to be only loosely held in place. The masonry wall where this was located is at elevation $722 \mathrm{ft} .-6$ in. in the cable vault structure. In addition, a vertical angle did not have an anchor at the top and no washers were present at other anchors where oversized holes were used in the angle.

2. At elevation $722 \mathrm{ft} .-6$ in. a long, large crack in the concrete ceiling was observed. Signs of rust discoloration were also present (Plate 26).

3. Corrosion was observed in the raw cooling water piping and steel supports for the condensing unit of the control room air conditioning. This was identified at elevation $722 \mathrm{ft} .-6$ in. 
4. At elevation $735 \mathrm{ft} .-6$ in. grout degradation was observed below the baseplate support to the $\mathrm{CCR}$ heat exchanger $1 \mathrm{~A}$ pressure gauge (Plate 26).

Service Building

1. At elevations $713 \mathrm{ft} .-6$ in. and $725 \mathrm{ft} .-6$ in., the concrete ceilings exhibited signs of water infiltration and calcium formation Plate 27).

2. Degradation of the foundation and corrosion of steel supports were observed in the switchgear room, elevation $713 \mathrm{ft} .-6$ in. (Plate 28).

3. Cracks in the masonry wall next to the computer room at elevation $735 \mathrm{ft}$. of the control room were identified.

Cable Vault structure

1. Cracks were identified in the masonry wall on elevation $735 \mathrm{ft}$. of the West cable vault.

2. Water from the fan coil unit drain line at elevation $735 \mathrm{ft}$. was corroding the base/steel supports.

3. Corrosion of the structural steel frame supporting the main steam and feedwater piping was observed at elevation $762 \mathrm{ft}$. roof level.

Safeguards structure

1. Corrosion of the sliding support plates for the river water piping was observed at elevation $722 \mathrm{ft}$. (Plate 27).

2. Corrosion of two pipe support base plates was identified on the ceiling above elevation $722 \mathrm{ft}$.

3. Water infiltration and corrosion of steel angles at the ceiling, adjacent to the exterior containment wall, was observed at elevation $747 \mathrm{ft}$. (Plate 23).

other structures

1. Steam Generator Drain Tank - cracks, water infiltration and calcium formation was observed at the West wall (Plate 25). 

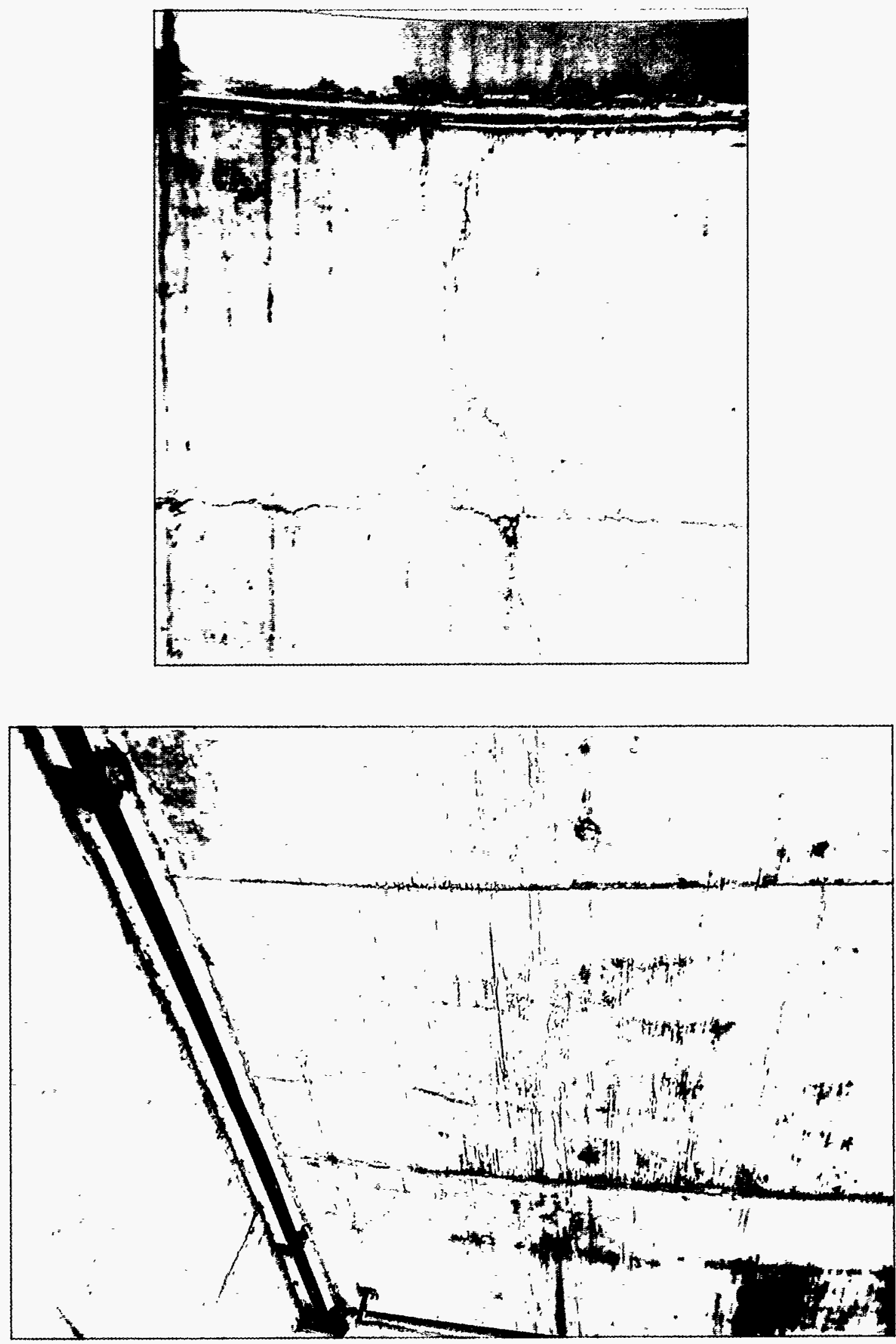

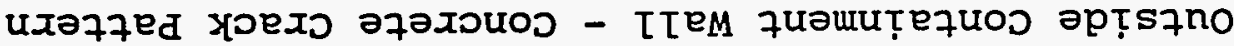

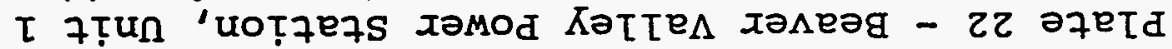


Plate 23 - Beaver Valley Power station, Unit 1

A- Containment; B- Safeguards Structure

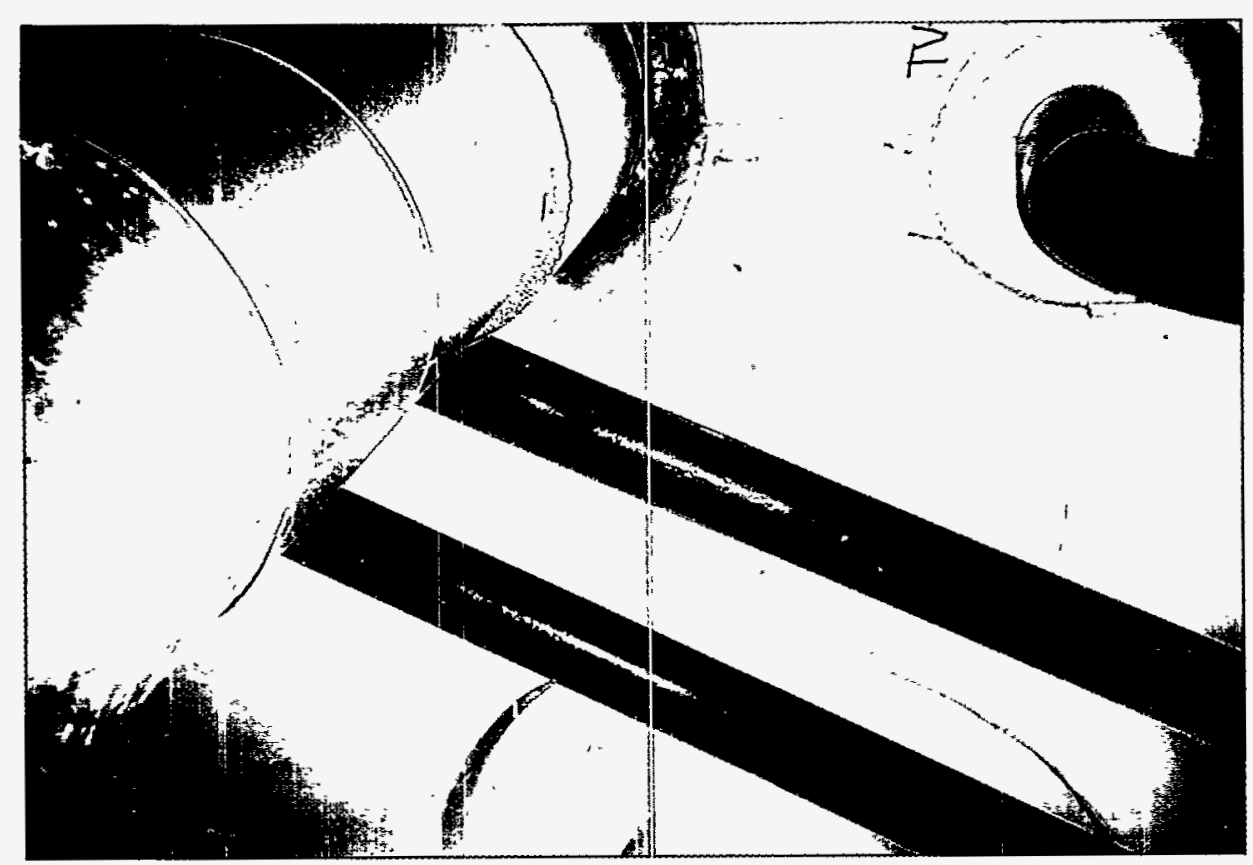

A - Corrosion of Containment Penetration

for Component Cooling Line

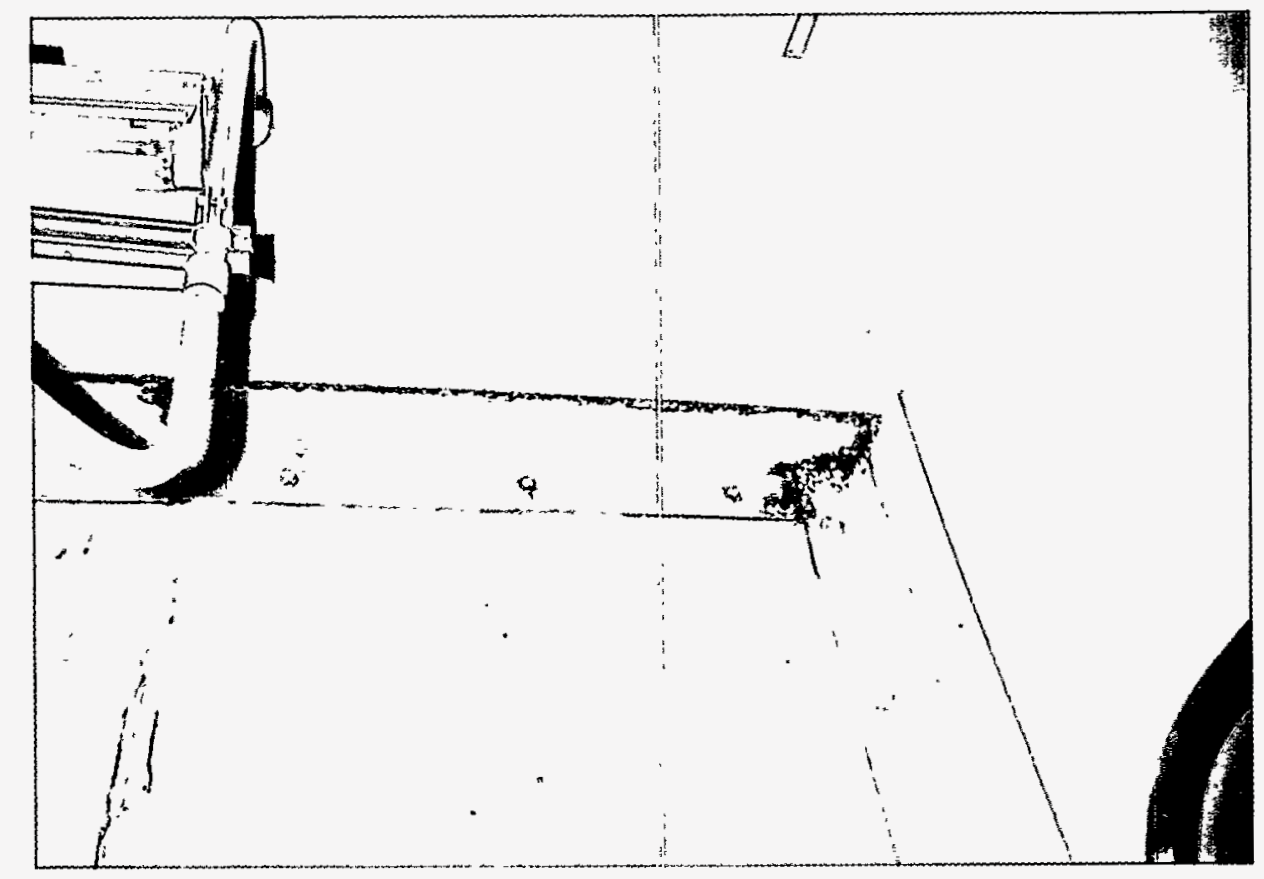

B - Water Infiltration and Corrosion of Steel Angles 
Plate 24 - Beaver Valley Power Station, Unit 1 Intake structure

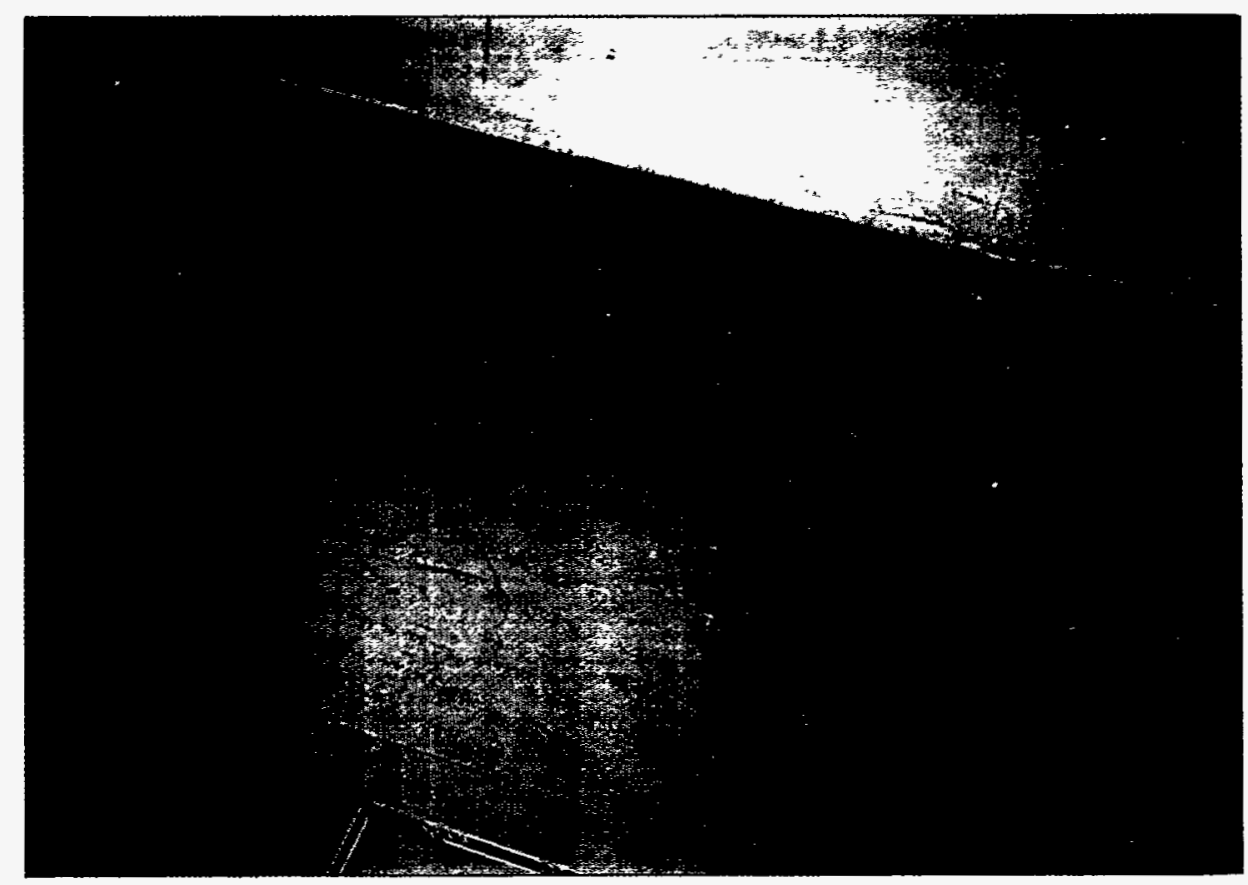

Diagonal Cracks Near Access Panels to Pump Cubicle

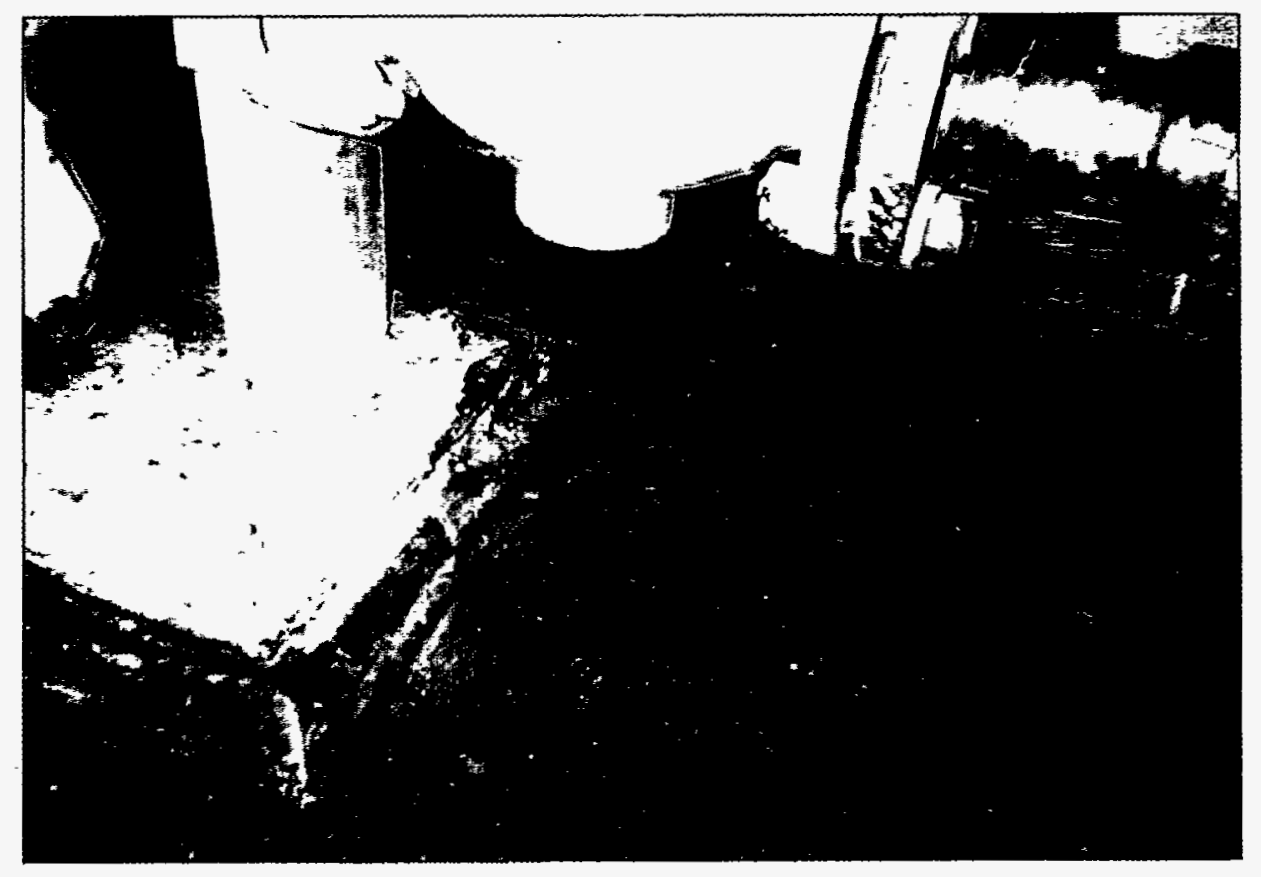

Grout Degradation and Baseplate Corrosion 

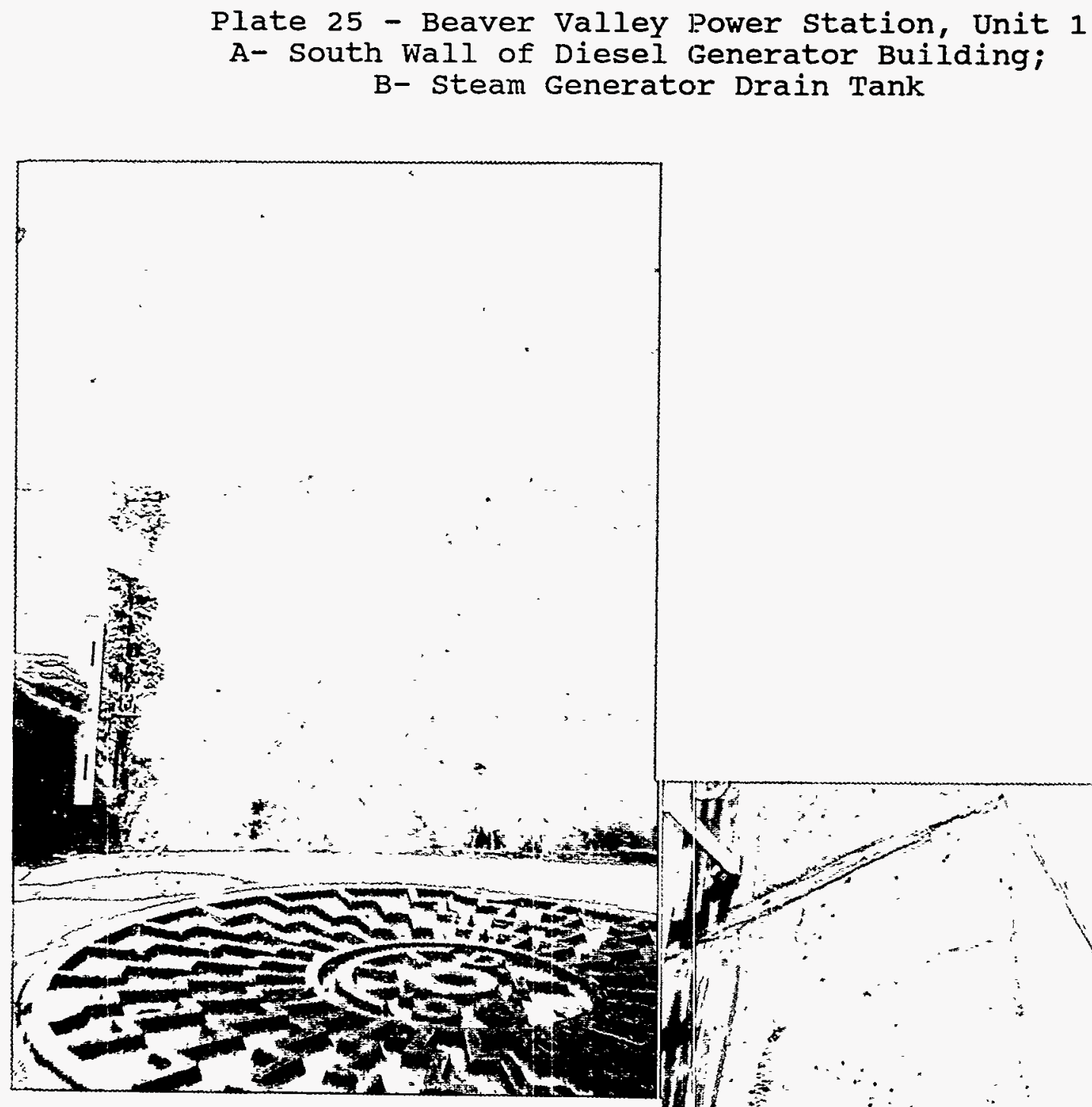

A - Concrete Spall and Corrosion of Reinforcement

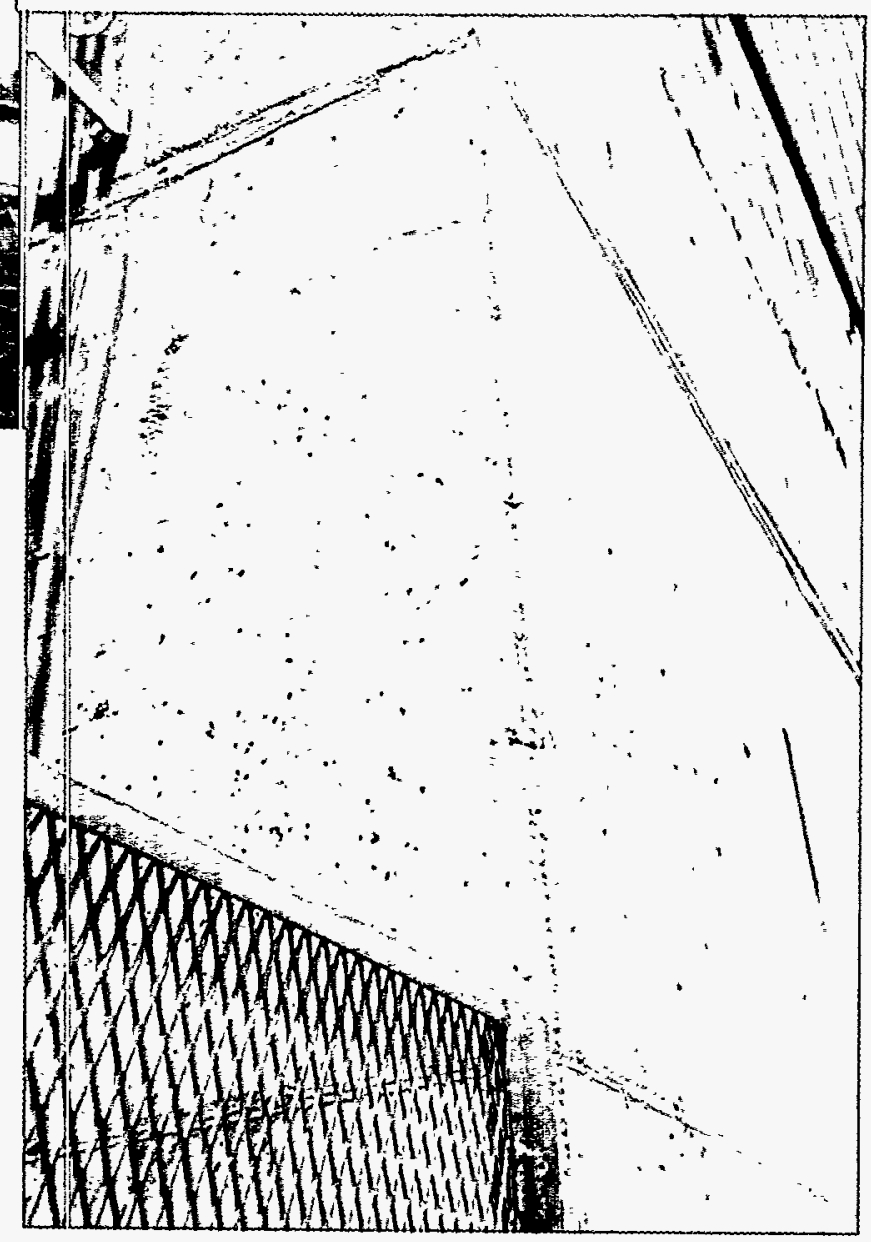
B - Cracks, Water Infiltration, and Calcium Formation




\section{Plate 26 - Beaver Valley Power Station, Unit 1 Primary Auxiliary Building}

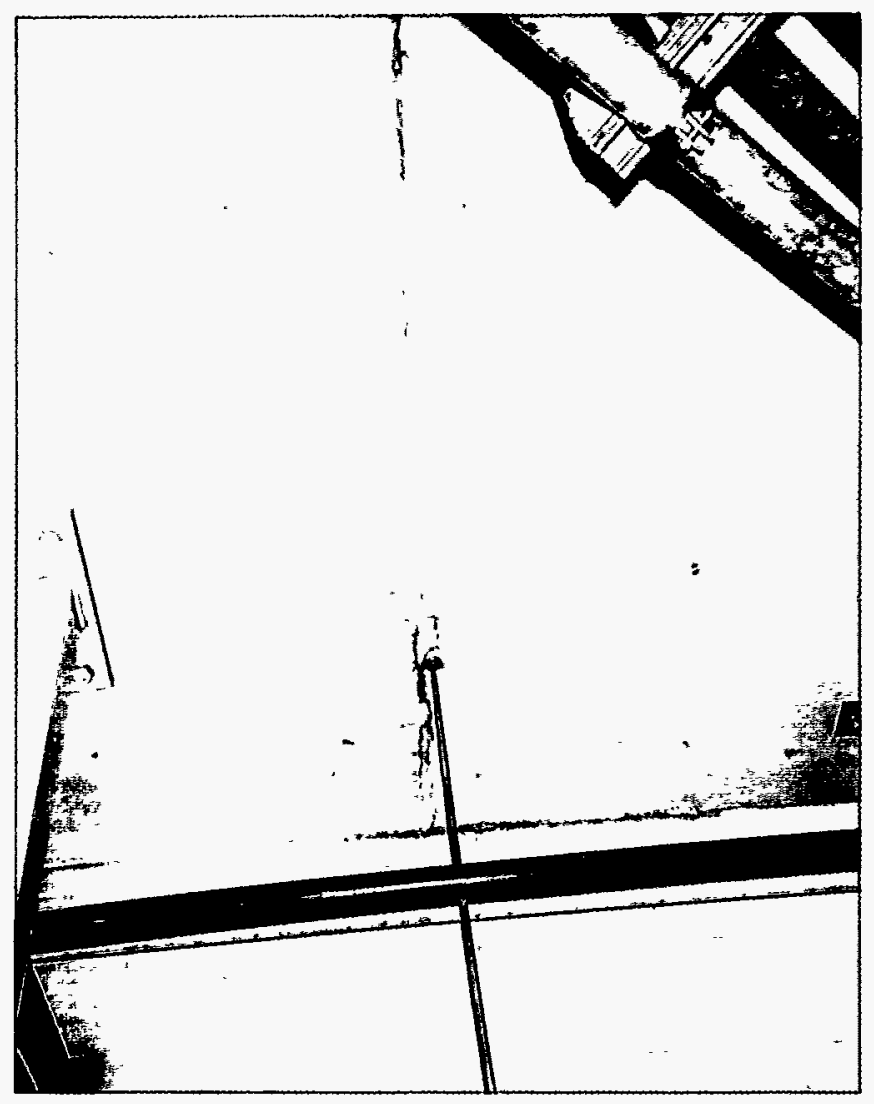

Concrete Crack and Discoloration at Ceiling

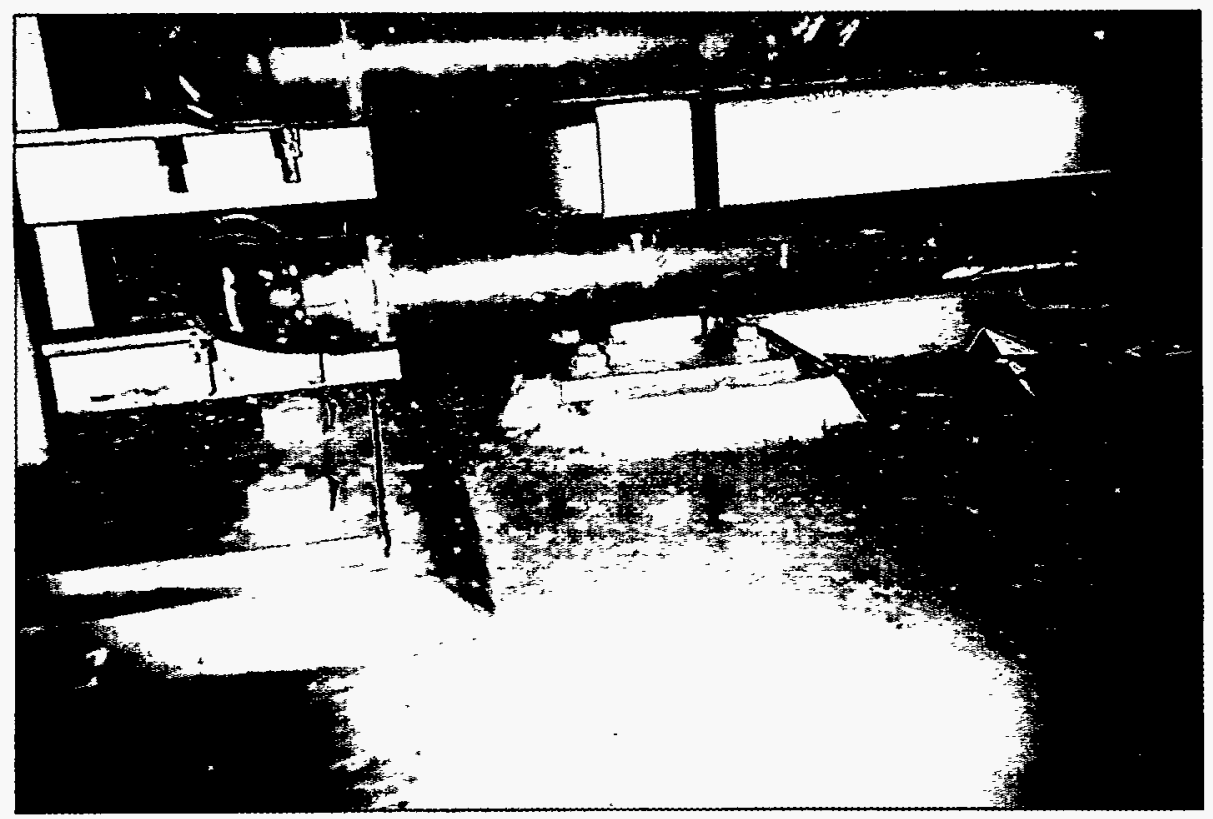

Missing/Degraded Grout Below Baseplate 
Plate 27 - Beaver Valley Power station, Unit 1 A- Safeguards Structure; B- Service Building

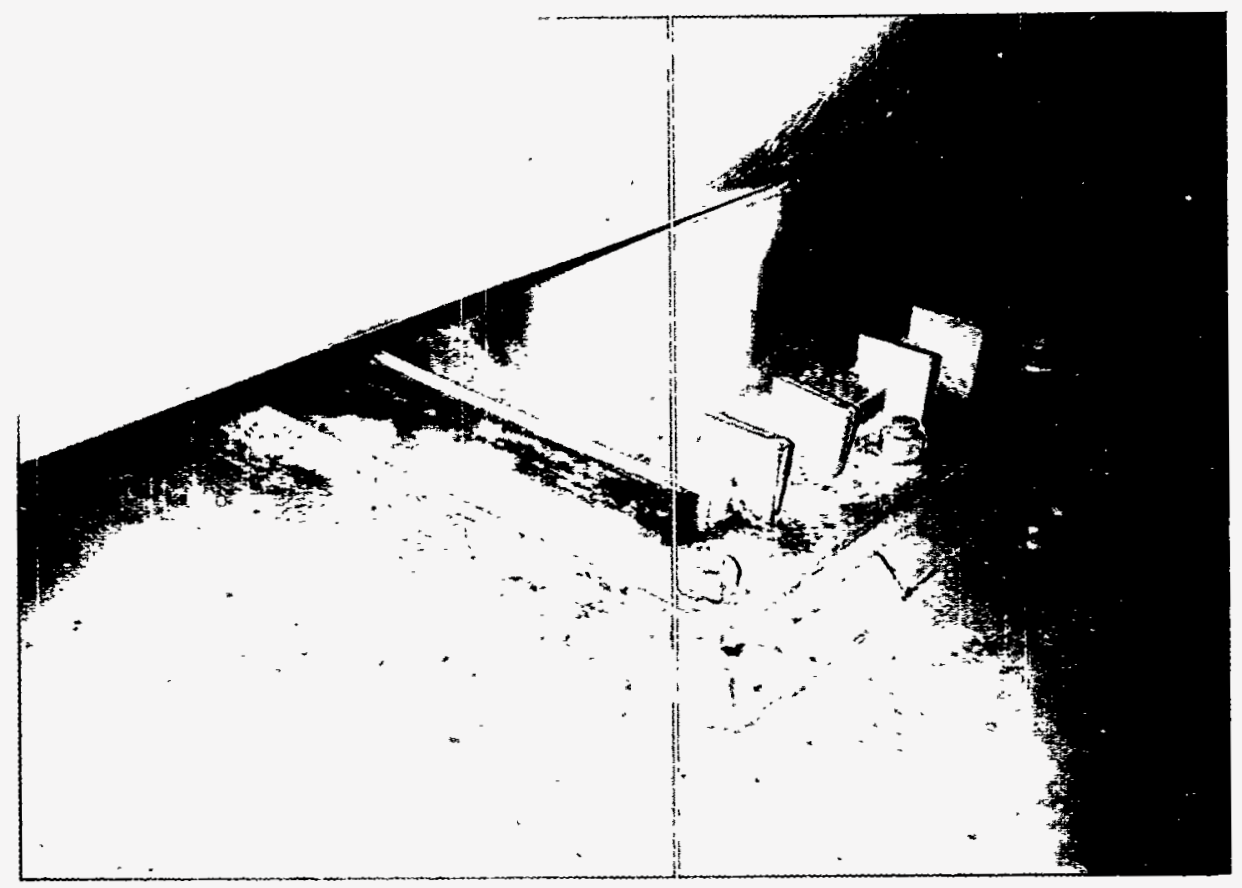

A - Corrosion of Sliding Support

Plates for River Water Piping

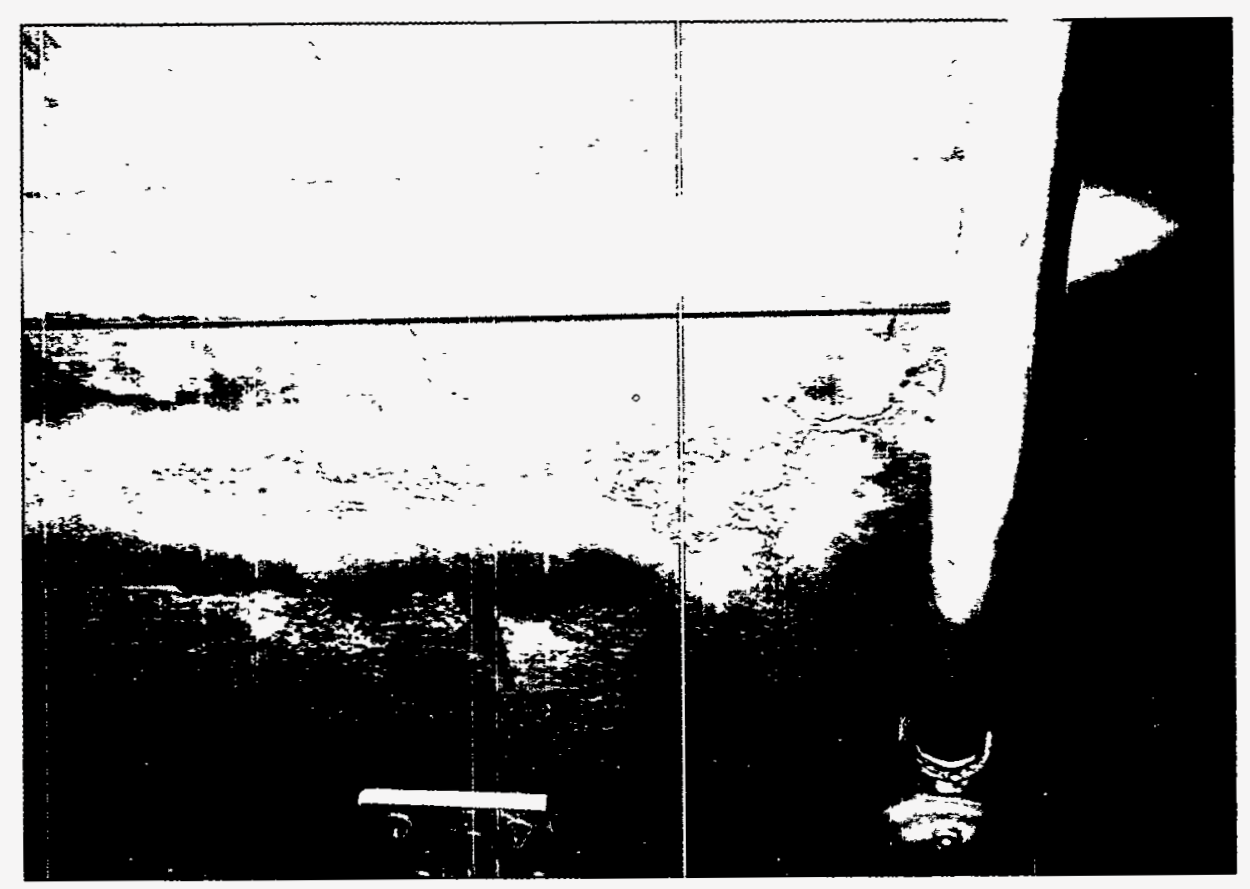

B - Water Infiltration and Calcium Formation 


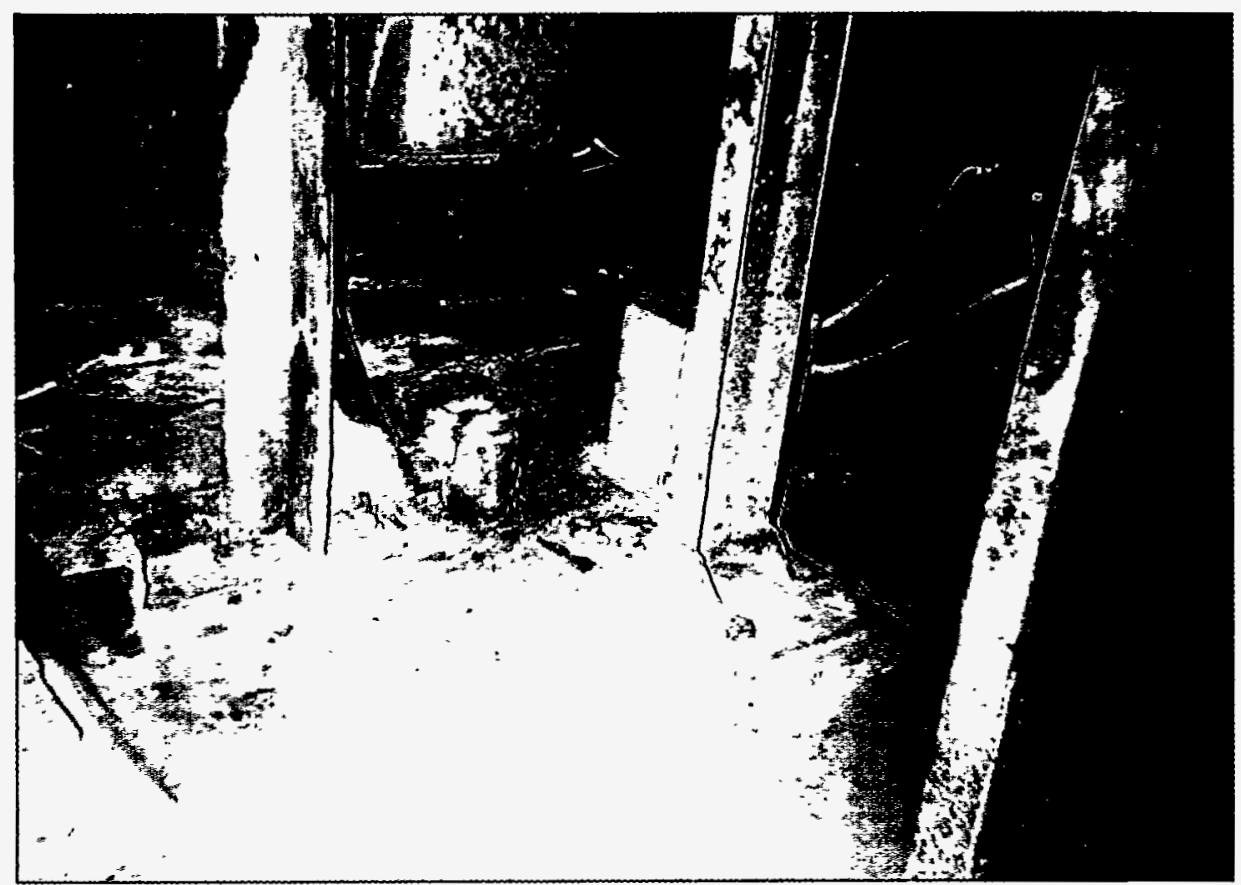

Degradation of Base/Foundation and Corrosion of Steel Supports

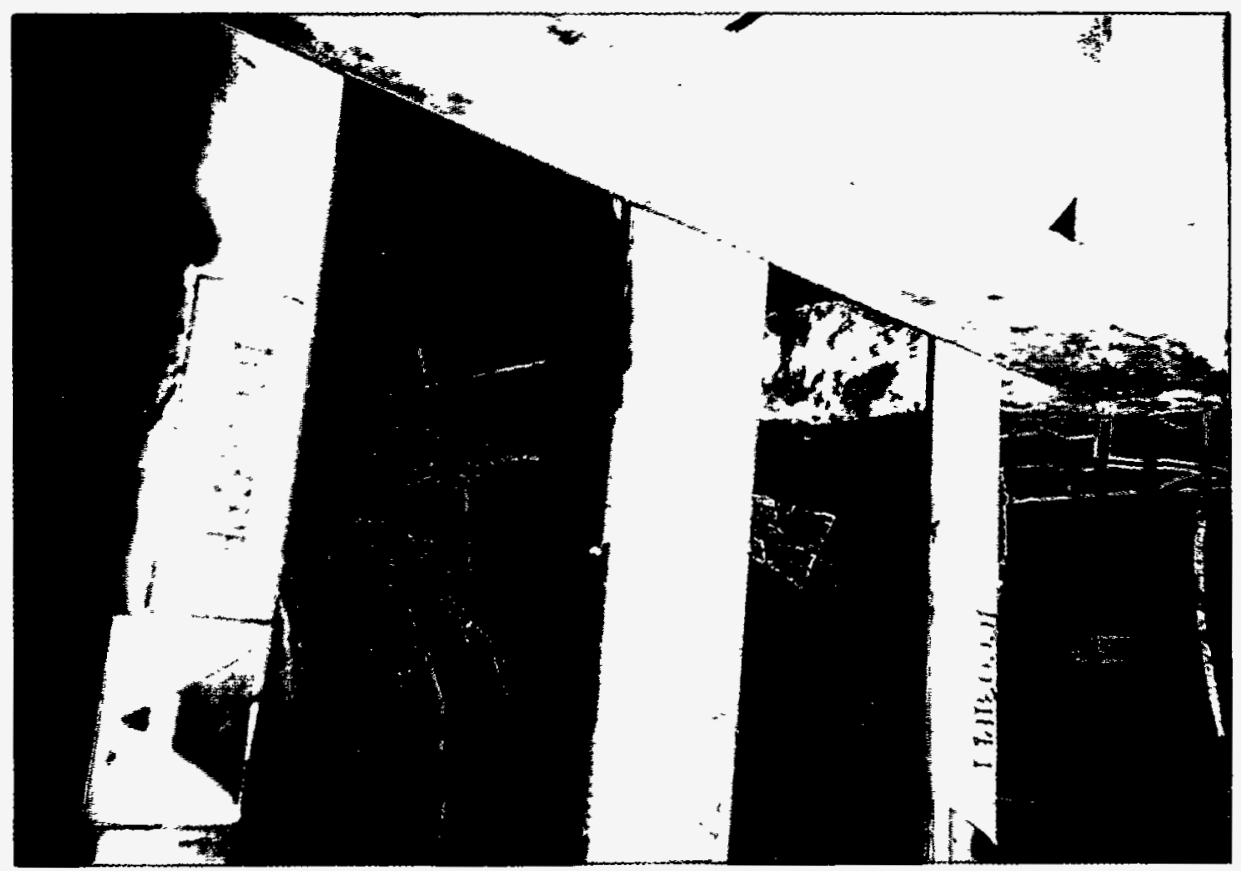

Metal Corrosion of Frame Support 



\section{COOPER NUCLEAR STATION}

Walkdown Description

August 18, 1992:

A formal presentation was made by Nebraska Public Power District (NPPD) personnel. The major topics covered include design criteria, site geology/foundation conditions, settlement/structural boundaries, structural surveillance programs, Mark I torus, intake structure, spent fuel pool/racks, tanks, containment, and support anchorages.

August 19, 1992:

The audit team remained together during the plant walkdown activities this day. The first area visited was the reactor building outside containment. Access inside containment was not possible since the plant was operating at the time. The walkdown began at the top elevation refueling floor and proceeded down to the lower elevations ending up at the torus enclosure. The building structural components examined include the concrete walls, floors, and ceilings and structural steel at elevations $1001 \mathrm{ft}$., $904 \mathrm{ft} ., 976 \mathrm{ft} ., 958 \mathrm{ft} ., 931 \mathrm{ft} ., 881 \mathrm{ft} .$, and $859 \mathrm{ft}$. Included in this review was examination of the drywell hatch, tanks, masonry walls, penetrations, conduit/supports, piping supports, equipment supports, anchorages, and the torus/supports.

Next, the team examined the roof and interior portions of the control building at elevations $948 \mathrm{ft} ., 932 \mathrm{ft} ., 918 \mathrm{ft},, 904 \mathrm{ft}$, $882 \mathrm{ft}$. , and $877 \mathrm{ft}$. The structural components reviewed include the concrete walls, floors, and ceilings; building structural steel; conduit/supports; cable tray/supports; equipment supports; pipe supports; support anchorages; and tanks. Specific areas reviewed include the control corridor, roof, cable spreading room, control room, auxiliary relay room, battery room, DC switchgear room, and emergency condensate storage tank. While on the control building roof, the exterior walls of the reactor building were also examined.

August 20, 1992:

To ensure completion of the walkdown in the allotted time, the audit team was split into two groups; $A$ and $B$.

Team $A$ examined the interior of the radwaste building at elevation $875 \mathrm{ft}$. and basemat and the interior of the turbine building at elevations $932 \mathrm{ft}, 875 \mathrm{ft}$, and $903 \mathrm{ft}$. NPPD had informed the audit team that the only safety-related area in the radwaste building is at the lowest level (basemat) and the turbine building has no safety-related area/components. Team $A$ also 
reviewed the interior and exterior portions of the intake structure.

While Team $A$ was performing the walkdown described above, Team $B$ examined the diesel generator rooms, exterior walls of the control building and reactor building, the buried diesel oil tank area, and the elevated release point tower. Team B also examined the exterior and interior portions of the intake structure.

Both teams examined the exterior and interior portions of the intake structure at the grade level (operating floor elevation). Access below the operating floor down to the water level could not be readily obtained. However, visual examination from the operating floor of all the bays in front of the traveling screens down to the water level were made. In addition, walkdowns were performed in the service water pump room.

Structural components reviewed in the areas described above include concrete floors, walls, and ceilings; building structural steel; conduit/supports; cable tray/supports; piping supports; anchorages; seismic gaps between buildings; equipment supports; tanks; and masonry walls. This concluded the walkdown activities.

In the afternoon, the audit team reviewed several LERs and 10 CFR 50.59 evaluation packages related to civil/structural items. These were selected from a list provided by NPPD during their presentation.

\section{Results/Observations}

1. Signs of corrosion were observed on the external surface of the torus shell, near torus support \#7. The normally reddish color of the torus shell now had dark streaks on it (Plate 29). Apparently, a leak from above the torus has been running down the torus shell wall, on both the inner and outer side. This has removed the reddish coating and has initiated surface corrosion of the shell.

2. Evidence of water leakage through a piping penetration in the exterior concrete wall of the Reactor Building was observed from inside the torus enclosure (Plate 29). The water apparently ran down along the wall onto some conduit adjacent to the wall. NPPD was aware of this situation, indicating the source of the water is from surface runoff during heavy rainfall. However, it appears that no effort has been made to stop the water infiltration.

3. In the service water pump room of the intake structure, corrosion of piping and pipe supports as well as degradation of anchorages and floor coating were observed (Plates 30 and 31). Better housekeeping and maintenance of the equipment, piping, supports, anchorages, and floor is recommended. In addition, in view of the condition in the service water pump room and excessive water on the operating floor outside the pump room, 
inspections of the concrete and steel structure should be periodically performed; particularly in areas that are not visible or readily accessible.

4. At elevation $904 \mathrm{ft}$. in the control building, the RHR service water booster pump (SWBP) gland water system is in a very bad state of corrosion and degradation. This includes the tanks, piping, supports, and anchorages (Plate 32). NPPD was aware of this condition, indicating that they plan to remove the system completely since it is not required. NPPD stated that they plan to remove it during the 1993 refueling outage. However, the system has been allowed to continue to operate in this condition for a number of years.

5. At elevation $882 \mathrm{ft}$. in the control building, the service water booster pump system was observed to be in a degraded condition. Corrosion was identified on the piping, pump B, valve SW-85, and on several flange connections (Plate 33).

6. At elevation $877 \mathrm{ft}$. in the control building, several horizontal pipes near the ceiling over the emergency storage tank appear to show signs of corrosion.

7. Several instances of cracks in concrete floors and walls were observed. These include the floor at elevation $882 \mathrm{ft}$. in the service water booster pump room and west wall (floor to ceiling); exterior wall of the diesel generator structure on the North end and East end; floor at elevation $958 \mathrm{ft}$. of the reactor building (MG pump area); and the crack/spalled concrete of the reactor building exterior wall at the junction of upper and lower levels (North East corner) (Plate 34). Although these cracks are not severe, it would be prudent to monitor them to ensure they do not worsen and lead to degradation of the structure.

8. A number of instances of potential connection/anchorage problems were observed. These include: missing bolt/nut at cable tray splice plate in the cable expansion room, (cable tray \# C227 near hanger \#65), conduit support anchor angularity about $10^{\circ}-15^{\circ}$ (excessive) and a gap exists between the anchor head and plate in the cable expansion room, insufficient thread engagement of anchor nuts in a base plate for the service water line near valve SW-125 at elevation $931 \mathrm{ft}$. of the reactor building, and missing anchors at base angle attached to corrugated steel supports to a masonry wall at elevation 931 ft. of the reactor building.

9. At the base of the structural steel leg of the elevated release point tower (North West corner) the coating has peeled off and corrosion of the base material is evident (Plate 34 ).

10. If epoxy-dipped anchors are used in high temperature areas, then evaluation for possible hardening and brittleness of the 
epoxy and the capacity of the anchors should be evaluated. In addition, the letter to the NRC regarding IE Bulletin 79-02 Resolution describes criteria and plans to resolve the IE Bulletin but does not give any schedule for its completion.

11. As a result of past internal inspections of the torus, NPPD identified numerous cases of corrosion pits in 4 of the 16 bays examined. The existing pits were analyzed with a corrosion growth factor which would conservatively allow for all pits to remain uncoated until the 1993 scheduled refueling outage. However, NPPD decided to patch the 150 pits identified in the 4 bays using underwater cured epoxy.

The audit team expressed a concern about pits in other bays that were not inspected and about the ability of the underwater cured epoxy to arrest the problem. NPPD indicated that the epoxy used was Brutem 15 and "when applied properly, will displace water and trapped air in the repair zone.

The patches will be evaluated during the 1993 scheduled refueling outage and this evaluation should provide justification for the use of underwater applied epoxy.

12. NPPD indicated that ultrasonic testing (UT) of the service water and residual heat removal service water booster system piping, fittings, and valves is routinely performed as part of the Augmented Erosion-Corrosion Program. This program is concerned with lower pressure systems that could be subjected to erosion caused by the silty Missouri River water. The Augmented Erosion-Corrosion Program contains those items which are potentially subject to wall loss, but are not flagged by the criteria of the Erosion-Corrosion Program. 


\section{Plate 29 - Cooper Nuclear Station \\ Reactor Building}

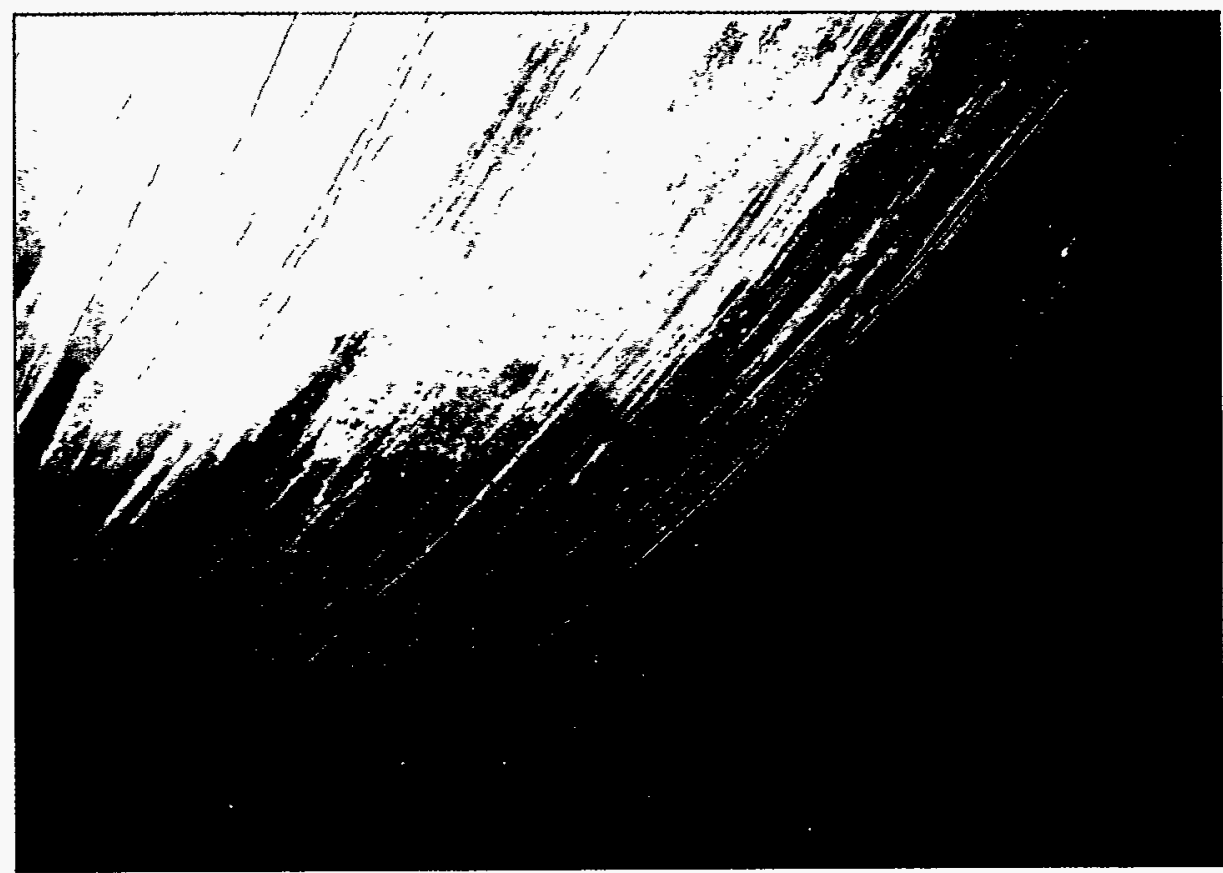

Torus - Surface Corrosion

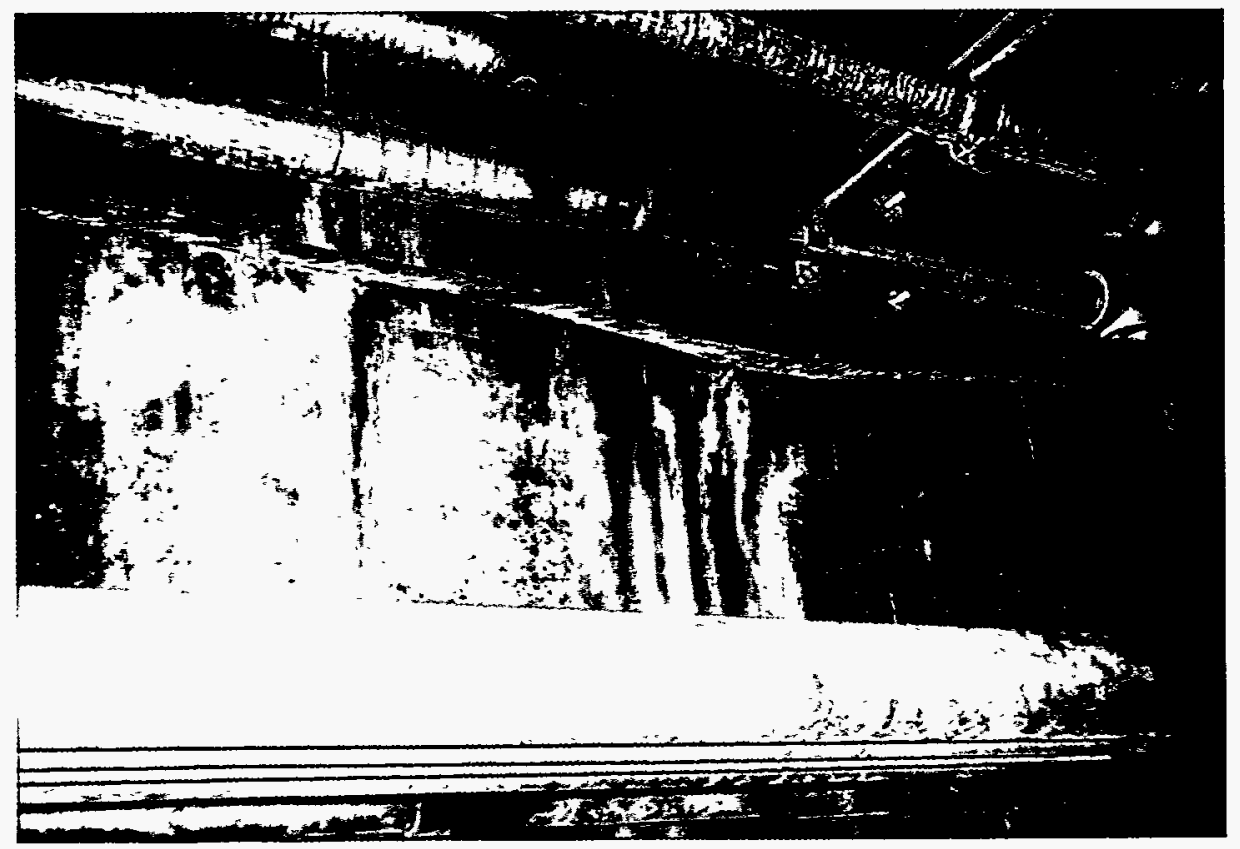

Exterior Concrete Wall - Water Infiltration 
Plate 30- Cooper Nuclear Station

Intake structure, Service Water Pump Room - Degradation

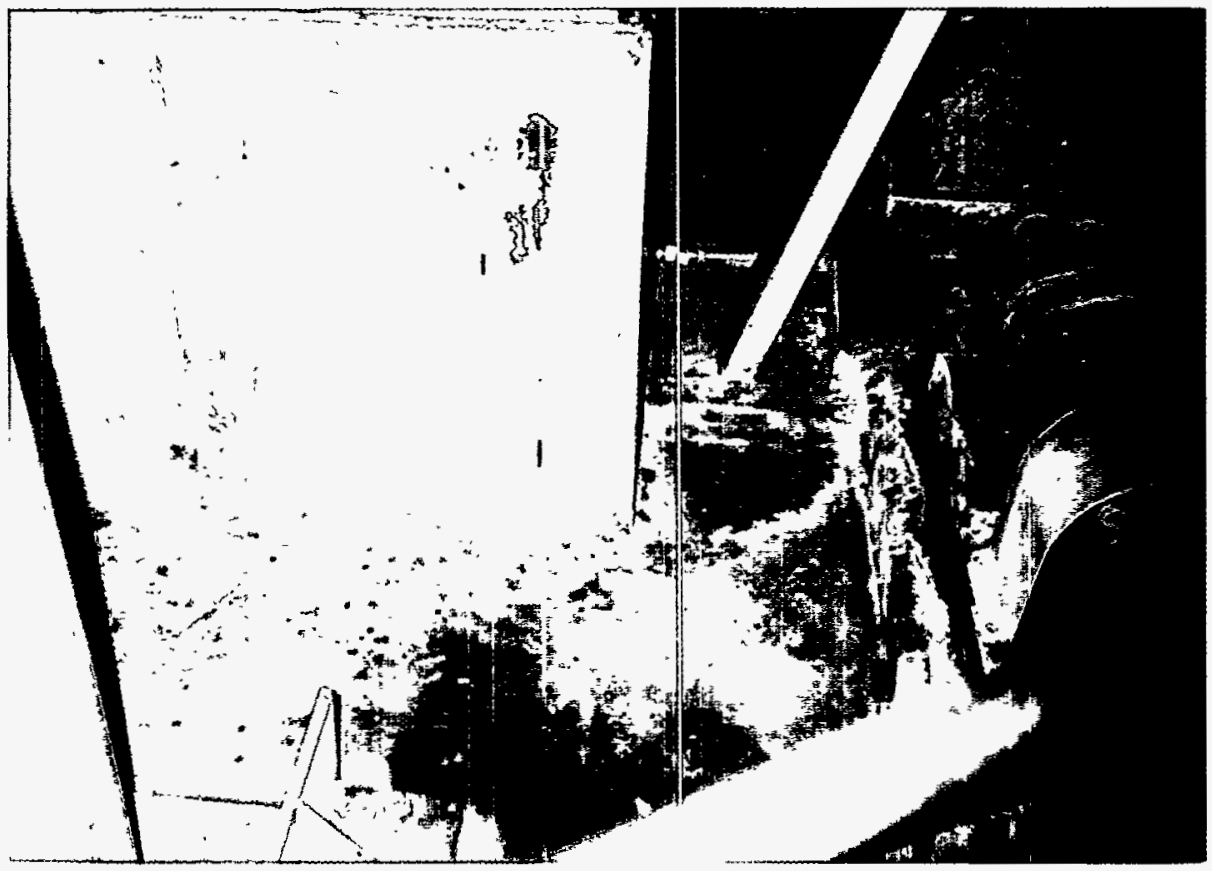

Structural Supports and Anchorage Areas

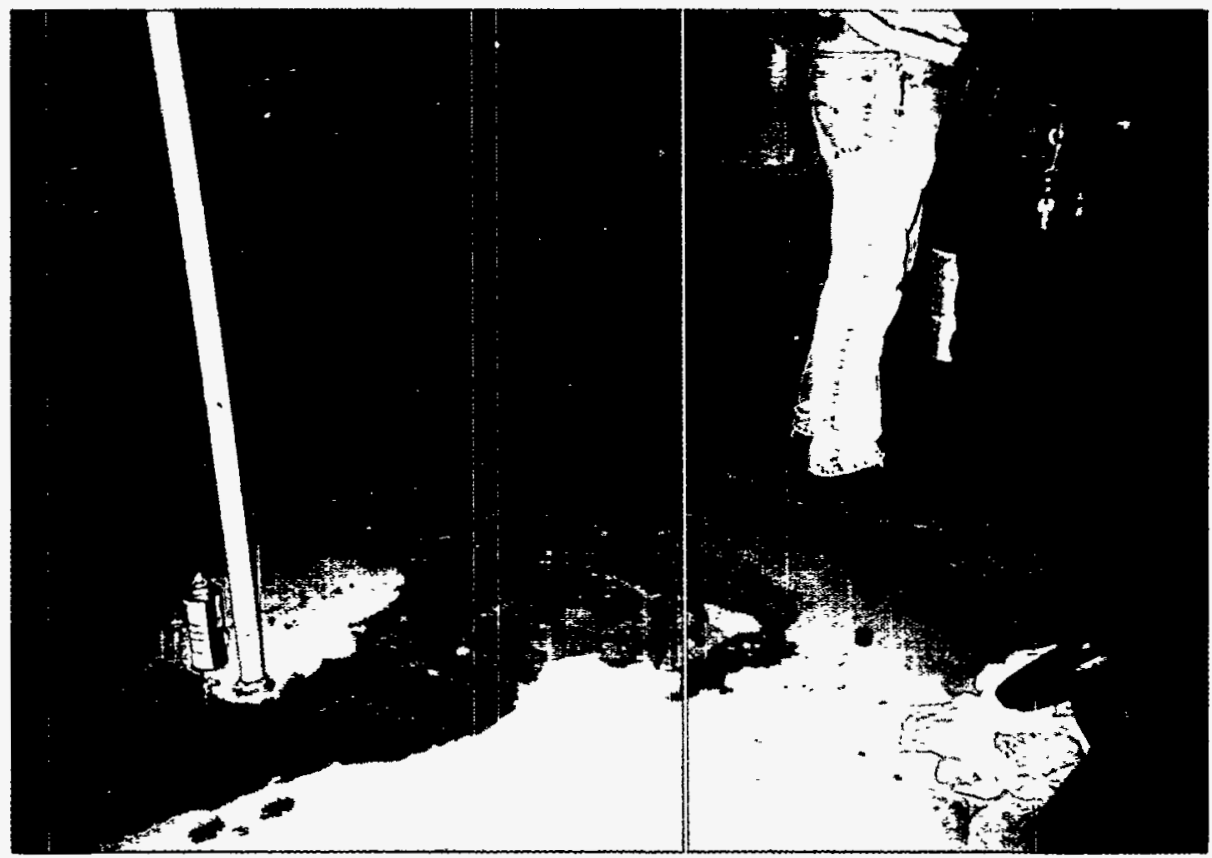

Floor Coating 


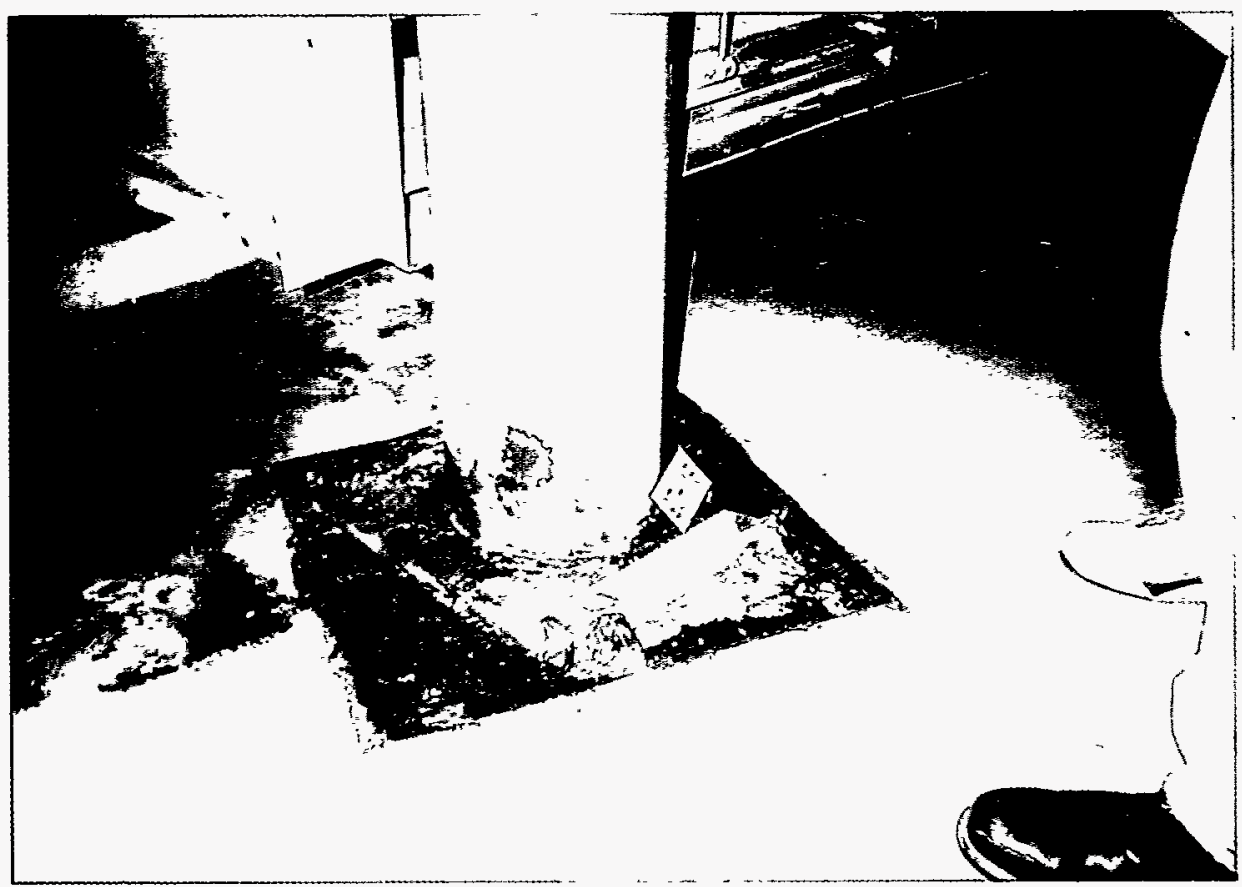

Pipe Support

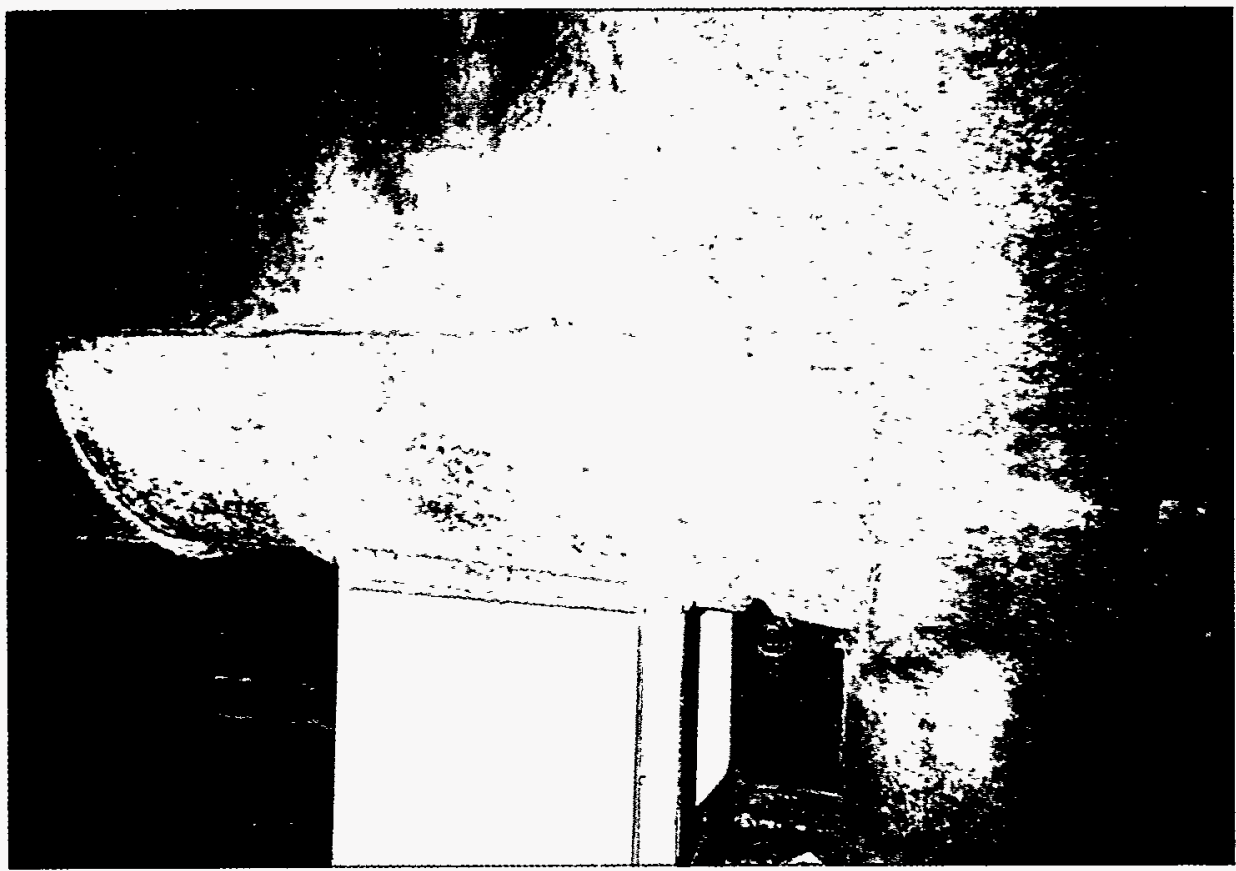

SW Piping 
Plate 32 - Cooper Nuclear Station

Control Building, Service Water Gland Water system Corrosion/Degradation
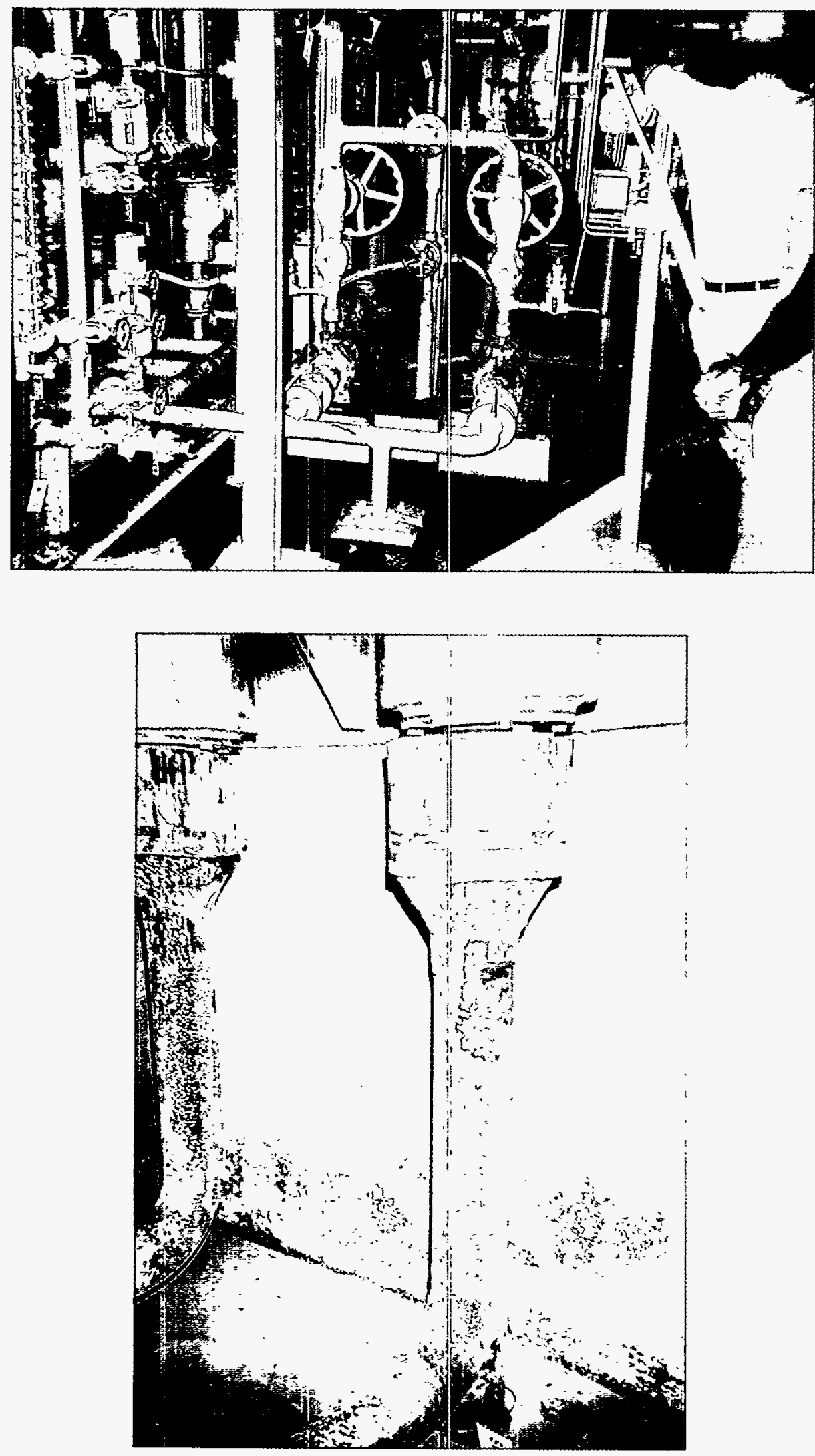

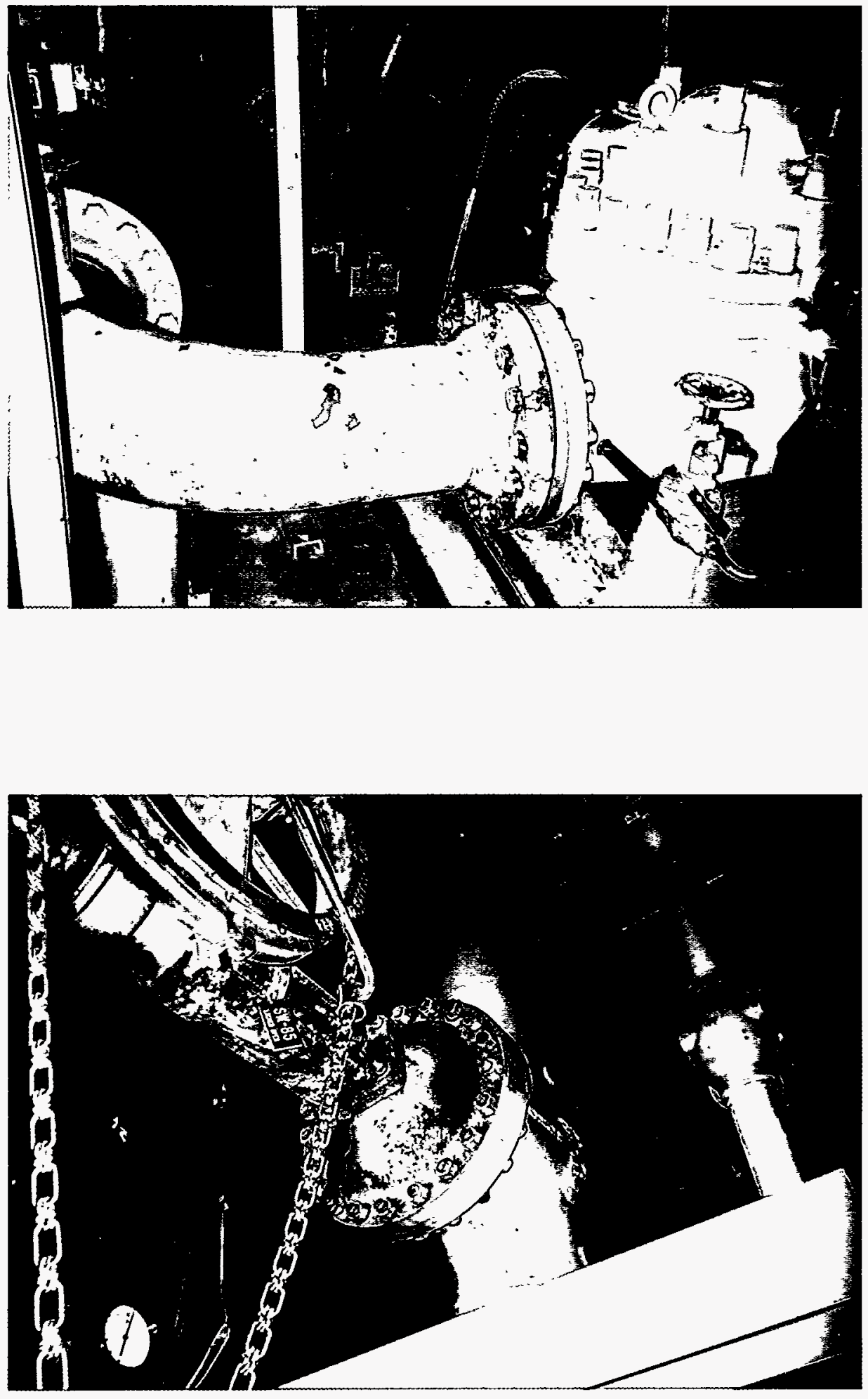

Valve Corrosion 


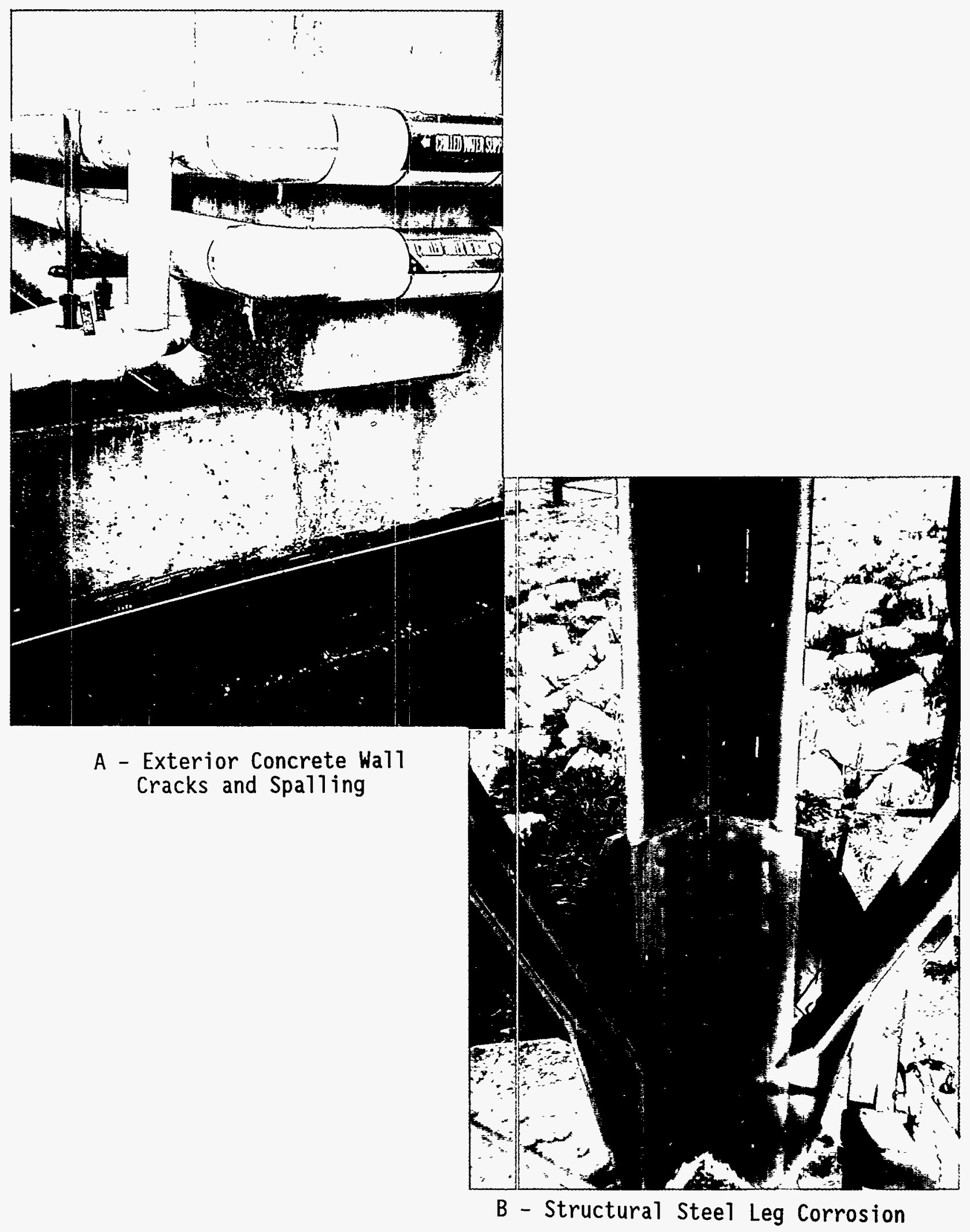




\section{CONCLUSIONS AND RECOMMENDATIONS}

\section{Conclusions}

Considering that the plants reviewed have been operating for an average of 19 years, most civil/structural plant features have performed very well. Some structures/components, however, do show signs of aging degradation.

The various degradations summarized in the preceding chapters and listed in Chapters 3 through 8 are classified under eleven (11) categories. The degradation categories are listed and sequentially numbered in Table 9-1. For each plant a rating is assigned to each category to identify its significance for that specific plant.

The rating system consists of:

$\mathrm{H}$ - High (instances of a more significant nature)

M - Medium (several instances of a moderate nature)

L - Low (very few instances of a non-significant nature)

N/A - Category not applicable

Table 9-2 presents this information for the six (6) plants visited. It is important to emphasize that the ratings are not judgements about the current overall safety condition of these specific plants. The ratings indicate the plant-specific historical experience and current remediation programs, as well as physical observations by the audit team. The information provided by the Licensee during the presentation and during the walkdowns was invaluable. Without the assistance of the Licensee's staff at each plant, the value of this effo

rt would have been significantly reduced.

The last row of Table 9-2 is entitled, "Generic Issue Rating". This represents a "qualitative mean" of the six plants for each of the categories. Thus, a Generic Issue Rating of $\mathrm{H}$ (or high rating) for Category 5, as an example, indicates that tendon gallery degradation was significant at the plants which have tendon galleries.

Recommendations

Table 9-3 presents significance ratings for each category for the following NRC licensing activities:

- Operating Plant Safety

- License Renewal Application

- New Plant Design'Certification/License Application

Note that the ratings for operating Plant safety are the same as the "Generic Issue" ratings from Table 9-2 with the exception of 
category numbers 1,7, and 11 which are discussed below. Each of these areas is addressed in the following paragraphs.

\section{Operating Plant Safety}

The categories rated "H" are candidates for generic letters or information notices to the Licensees, if generic communications related to these categories have not already been issued. The categories rated "M" may be candidates for generic letters or information notices. As a first step, it would be prudent to request that residents and regional inspectors assess the history and current condition of additional plants with respect to these "medium" categories. The ratings would then be adjusted, based on the additional input; the appropriate action would be selected based on the revised ratings.

\section{License Renewal Application}

The information collected during the six-plant audit has been evaluated from the perspective of license renewal for an additional twenty years of operation, beyond the original forty-year design life.

The ratings in Table 9-3 provide guidance for identifying the types of degradation which may require detailed review during the license renewal process. Several categories which are rated "M" for operating plant safety have been elevated to " $\mathrm{H}$ " for license renewal application, because of the increased service life.

For prestressed concrete containments, maintaining the prestressing system components in good working order is essential. Also it will be necessary to ensure that the required level of prestress can be maintained through the life extension period.

For steel containments, such as Mark I, sources of corrosion will have to be identified and eliminated, and an on-going inspection program will be required to ensure that minimum wall thickness requirements are not violated throughout the life extension period.

Problems with corrosion, erosion, and blockage of service water system piping and components are pervasive. Appropriate repairs or retrofits may be required to ensure the safety-related function of the service water system through the life extension period.

The intake structure and associated concrete structures are particularly susceptible to degradation from the elements. This is a major concern at coastal areas where the intake structure is exposed to a salt water environment. A regular inspection and maintenance program is necessary for license renewal. In the worst situation, rebuilding portions of the structure may be necessary to ensure a ready supply of suitable service water. 
Under the Bulletin 80-11 program, all existing masonry walls important to safety had to be qualified for appropriate combinations of operating and severe loadings. Specifically, their capability to survive a design-basis seismic event was questioned and each Licensee had to demonstrate that its masonry walls satisfied criteria acceptable to the NRC. The basis for qualification of masonry walls varied widely - from conservative simplified analysis to installation of major reinforcement schemes. Whatever the basis, it is necessary to ensure that this basis is maintained throughout the plant life including the license renewal period. Regular inspection and maintenance is required to maintain the walls in their originally qualified condition.

The condition of safety-related storage tanks and buried piping must be evaluated before an extension of service life can be approved. These elements are difficult and costly to inspect and are often overlooked by the Licensee. It would be prudent to require detailed, well documented inspections, structural evaluation of the current condition and a conservative estimate of remaining service life as part of the license renewal application.

New Plant Design Certification/Licensing Application

The information collected during the six-plant audit has been evaluated from the perspective of new plant design certification/licensing for a sixty-year design life. This is consistent with recent submittals to the NRC for review of evolutionary and advanced reactor designs. The significance ratings in Table 9-3 provide guidance for identifying the types of potential degradation which need to be addressed during the new plant design certification/licensing process. The ratings, by category, are very similar to those specified for license renewal.

Given the operating experience logged to date by the commercial nuclear industry, the next generation nuclear power plant - whether it utilizes an evolutionary reactor design or an advanced reactor design - should improve on the performance of its predecessors. over the past twenty (20) years, the nuclear industry has had to address many operating problems which were not anticipated at the design stage. The lessons learned must be considered and then extrapolated to a sixty-year design life.

susceptibility to aging degradation is influenced by the following factors:

1) degree of knowledge and understanding of the aging mechanisms

2) design and materials selection

3) fabrication and construction methods

4) level of inspection and maintenance

The current state of knowledge and understanding about aging mechanisms should have a significant impact on the design, materials selection, fabrication, and construction of new nuclear 
power plant structures and civil engineering features. In addition, accessibility for periodic inspection and ease of maintenance should be important considerations at the detail design stage. This is particularly important for those degradation categories rated " $\mathrm{H}$ " in Table 9-3.

\section{Other Recommendations}

At two of the plants, Point Beach Units 1 and 2 and Turkey Point Units 3 and 4, cathodic protection systems (CPS) are relied upon to mitigate the degradation of structural steel components. At Point Beach, the CPS is used to prevent corrosion of the steel piles which support the containment and fuel pool basemats (see Plates 6-10). The Licensee relies on the CPS electrical readings to conclude that the system is functioning and consequently preventing corrosion. No visual or other verification means have been attempted. At Turkey Point, the CPS is used to prevent corrosion of the containment liner plate, reinforcing steel, and tendon assemblies (see Plates 11-15). In this case, the CPS is presently exhibiting low to very low readings in some of the anodes. The Licensee is presently evaluating this condition.

Although the use of CPS is a unique feature at very few plants, additional information on CPS and data on long term integrity of buried components should be reviewed. In some cases it may be necessary that physical inspection be performed to assess the performance of CPS in preventing corrosion of steel components.

In several plants, cracks were identified in masonry walls. Some of these masonry walls were believed to be unreinforced. In addition, one plant had a large gap between a structural steel support and the masonry wall. The structural steel apparently was intended to provide support to the wall. At another plant, a structural steel angle originally installed to restrain the bottom edge of a masonry wall, was found to be only loosely held in place. Also, a vertical angle did not have an anchor at the top and no washers were present at other anchors where oversized holes were used in the angle.

In the case of unreinforced masonry walls, the original seismic qualification typically relies on the bending capability of the masonry blocks and mortar joints without cracks. For the structural steel members which were installed to provide support to the masonry walls, the installation condition should reflect the seismic qualification basis (i.e., clirect support by the structural members without a gap). Therefore, it is recommended that a periodic inspection program, developed by the Licensee, should be performed to ensure that the condition of each seismic category I masonry wall reflects the intended design and assumptions used in the seismic qualification documentation. The inspection should include verification that no additional cracks appear in unreinforced masonry walls which were not considered in the original qualification of the wall. 
Although none of the plants had an adequate inspection program that encompassed all civil/structural features, a few plants did develop procedures for a limited review of selected items. At Beaver Valley Power Station, a Plant Inspection Program was developed (see Chapter 7). The purpose of this procedure is to ensure that deficiencies relating to materials, fire protection, safety hazards, cleanliness, housekeeping, and radiological protection are identified and that corrective action is taken. Under material condition deficiencies, items such as rust, corrosion, loose/unbraced lines/pipes, and leaks are identified.

Expansion of this type of program to cover other aging degradation effects such as concrete cracks, coating failures, and water infiltration would be very beneficial for maintaining the structural performance of nuclear power plants. Such inspection programs should be performed on a periodic basis depending on the type of structure and component examined. In addition, threshold values, such as size and length of cracks, should be specified which would trigger an evaluation of the condition and thus will ensure that some sort of action would be taken.

Based on the above, it is recommended that a periodic inspection program for safety related structures and civil engineering features be developed by each Licensee. The purpose of the inspection program is to identify any aging degradation that may be developing and to ensure that the degraded elements are evaluated and corrective actions taken if needed. These periodic inspections would also be very useful for trending of aging mechanisms for continuing operation, and for potential plant life extension. The frequency and level of inspection should be based on the location/environment (temperature, radiation, water, freezethaw, chemicals, etc.) susceptibility of the material/structure to degradation, and the current age of the structure. Periodic inspections every 5 to 10 years depending on the structure, environment, and age would seem appropriate. 
TABLE 9-1

DEGRADATION CATEGORIES

\begin{tabular}{|c|c|c|}
\hline 1 & - & Intake Structure/Pumphouse/Dam Degradation \\
\hline 2 & - & Service Water Piping System Degradation \\
\hline 3 & - & Water Infiltration \\
\hline 4 & - & Tendon Grease Leakage \\
\hline 5 & - & Tendon Gallery Degradation \\
\hline 6 & - & Masonry Wall Condition and Qualification Basis \\
\hline 7 & - & $\begin{array}{l}\text { Corrosion of Tanks, Buried Piping, Piles; Performance of } \\
\text { Cathodic Protection Systems }\end{array}$ \\
\hline 8 & - & $\begin{array}{l}\text { General Degradation of Concrete structures (other than } \\
\text { containment) }\end{array}$ \\
\hline 9 & - & $\begin{array}{l}\text { General Degradation of steel structures (other than } \\
\text { containment/liner) }\end{array}$ \\
\hline 10 & - & $\begin{array}{l}\text { Corrosion of Anchor Bolts/Grout Degradation/Anchorage } \\
\text { Deficiencies }\end{array}$ \\
\hline 11 & - & Containment structure/Tendon System/Liner Degradation \\
\hline
\end{tabular}


TABLE 9-2

DEGRADATION RATING

\begin{tabular}{|c|c|c|c|c|c|c|c|c|c|c|c|c|c|}
\hline \multirow{2}{*}{ Plant } & \multirow{2}{*}{$\begin{array}{l}\text { Reactor } \\
\text { Type }\end{array}$} & \multirow{2}{*}{$\begin{array}{l}\text { Containment } \\
\text { Type }\end{array}$} & \multicolumn{11}{|c|}{ Degradation Categories } \\
\hline & & & 1 & 2 & 3 & 4 & 5 & 6 & 7 & 8 & 9 & 10 & 11 \\
\hline Trojan & $\begin{array}{l}\text { PWR-W } \\
(1130 \text { MW) }\end{array}$ & $\begin{array}{l}\text { Prestressed } \\
\text { Concrete } \\
\text { (Type 3b) }\end{array}$ & $\mathrm{L}$ & $\mathrm{L}$ & $\mathrm{H}$ & $\mathrm{H}$ & $\mathrm{H}$ & $\mathbf{M}$ & $\mathbf{L}$ & $\mathbf{M}$ & L & L & $\mathbf{M}$ \\
\hline $\begin{array}{l}\text { Pt. Beach } \\
1 \& 2\end{array}$ & $\begin{array}{l}\text { PWR-W } \\
(500 \mathrm{MW} \\
\text { each) }\end{array}$ & $\begin{array}{l}\text { Prestressed } \\
\text { Concrete } \\
\text { (Type 3b) }\end{array}$ & $\mathbf{M}$ & $\mathrm{H}$ & $\mathbf{H}$ & $\mathbf{M}$ & $\mathrm{H}$ & $\mathbf{L}$ & $\mathrm{L}$ & $\mathbf{M}$ & L & $\mathbf{M}$ & $\mathrm{H}$ \\
\hline $\begin{array}{l}\text { Turkey } \\
\text { Point } \\
3 \& 4 \\
\end{array}$ & $\begin{array}{l}\text { PWR-W } \\
(728 \mathrm{MW} \\
\text { each) }\end{array}$ & $\begin{array}{l}\text { Prestressed } \\
\text { Concrete } \\
\text { (Type 3b) }\end{array}$ & $\mathrm{H}$ & $\mathrm{L}$ & $\mathrm{H}$ & $\mathrm{L}$ & $\mathrm{H}$ & $\mathbf{M}$ & $\mathbf{M}$ & M & $\mathrm{L}$ & $\mathrm{I}$ & $\mathbf{H}$ \\
\hline $\begin{array}{l}\text { Robinson } \\
2\end{array}$ & $\begin{array}{l}\text { PWR-W } \\
(665 \mathrm{MW})\end{array}$ & $\begin{array}{l}\text { Prestressed } \\
\text { Concrete } \\
\text { (Type 3a) }\end{array}$ & $\mathbf{M}$ & $\mathrm{H}$ & $\mathrm{I}$ & $\mathrm{N} / \mathrm{A}$ & $\mathrm{N} / \mathrm{A}$ & $\mathrm{L}$ & $\mathbf{L}$ & $\mathrm{L}$ & $\mathrm{L}$ & $\mathbf{M}$ & $\mathbf{M}$ \\
\hline $\begin{array}{l}\text { Beaver } \\
\text { Valley } 1\end{array}$ & $\begin{array}{l}\text { PWR-W } \\
(856 \mathrm{MW})\end{array}$ & $\begin{array}{l}\text { Reinforced } \\
\text { Concrete } \\
\text { (Type 3d) }\end{array}$ & $\mathbf{M}$ & $\mathbf{M}$ & $\mathrm{L}$ & $\mathrm{N} / \mathrm{A}$ & N/A & $\mathrm{H}$ & $\mathrm{L}$ & $\mathbf{M}$ & $\mathrm{L}$ & $\mathbf{M}$ & $\mathbf{M}$ \\
\hline Cooper & $\begin{array}{l}\text { BWR-GE } \\
(778 \mathrm{MW})\end{array}$ & $\begin{array}{l}\text { Steel } \\
\text { (Mark I) } \\
\text { (Type } 4 \mathrm{~g} \text { ) }\end{array}$ & $\mathbf{M}$ & $\mathrm{H}$ & $\mathrm{L}$ & $\mathrm{N} / \mathrm{A}$ & $\mathrm{N} / \mathrm{A}$ & $\mathrm{N} / \mathrm{A}$ & $\mathrm{L}$ & $\mathrm{L}$ & $\mathrm{L}$ & $\mathbf{M}$ & $\mathrm{H}$ \\
\hline \multicolumn{3}{|c|}{ Generic Issue Rating } & $\mathbf{M}$ & $\mathrm{H}$ & M & $\mathrm{M*}$ & $\mathrm{H} *$ & $\mathbf{M}$ & L & $\mathbf{M}$ & $\mathrm{L}$ & $\mathbf{M}$ & $\mathbf{M}$ \\
\hline
\end{tabular}

*Where applicable

Key: H - High (instances of a more significant nature) M - Medium (several instances of a moderate nature)

$L$ - Low (very few instances of a non-significant nature) N/A - Category not applicable

Note: These ratings are not judgements about the overall safety condition at the plants. They indicate the plant-specific historical experience, current remediation programs, and physical observations by the audit team. 
TABLE 9-3

APPLICATION TO FUTURE LICENSING ACTIVITIES

\begin{tabular}{|c|c|c|c|c|c|c|c|c|c|c|c|}
\hline \multirow{2}{*}{ Applicability to } & \multicolumn{11}{|c|}{ Degradation Categories } \\
\hline & 1 & 2 & 3 & 4 * & $5 *$ & 6 & 7 & 8 & 9 & 10 & 11 \\
\hline Operating Plants & $M / H^{\star \star}$ & $\mathrm{H}$ & $\mathbf{M}$ & $\mathbf{M}$ & $\mathrm{H}$ & M & $\mathbf{M}$ & $\mathbf{M}$ & $\mathrm{L}$ & $\mathbf{M}$ & $\mathrm{H}$ \\
\hline License Renewals & $\mathrm{H}$ & $\mathrm{H}$ & $\mathbf{M}$ & $\mathbf{M}$ & $\mathrm{H}$ & $\mathrm{H}$ & $\mathrm{H}$ & $\mathbf{M}$ & $\mathbf{M}$ & $\mathbf{M}$ & $\mathrm{H}$ \\
\hline $\begin{array}{l}\text { New Nuclear Power } \\
\text { Plants }\end{array}$ & $\mathrm{H}$ & $\mathrm{H}$ & $\mathbf{M}$ & $\mathbf{M}$ & $\mathrm{H}$ & 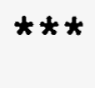 & $\mathrm{H}$ & $\mathbf{M}$ & $\mathbf{M}$ & $\mathbf{M}$ & $\mathrm{H}$ \\
\hline
\end{tabular}

Key: $\mathrm{H}$ - High importance

M - Medium importance

L - Low importance

N/A - Not applicable

* Where applicable.

** H rating is for coastal plants.

*** New design must meet current NRC restrictions and design criteria for masonry walls. 
Assessment of Inservice Conditions of Safety-Related Nuclear Plant Structures

3.

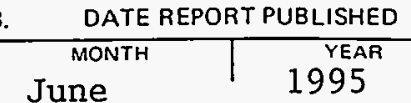

H. Ashar and G. Bagchi

8. PERFORMING ORGANIZATION - NAME AND ADDRESS IIf NRC, provide Division, Office or Region, U.S. Nuclear Regulatory Commission, and mailing address; if contractor, provide name and malling address,

Division of Engineering

Office of Nuclear Reactor Regulation

U.S. Nuclear Regulatory Commission

Washington, D.C. 20555-0001

9. SPONSORING ORGANIZATION - NAME AND ADDRESS (If NRC, type "Same as above"; if contractor, provide NRC Division, Office or Region, U.S. Nuclear Regulatory Commission, and malling address.)

Same as above

10. SUPPLEMENTARY NOTES Portions of the content of the report were presented at the 5 th Symposiu on-Current Issues-Related-to Nuclear Power-Plant-Structures, Equipment, and:Piging =- 11. ABSTRACT 1200 words orless) The report is a compilation from a number of sources of information related to the condition of structures and civil engineering features at operating nuclear power plants in the U.S. The most significant information came from the hands-on inspection of the six old plants (licensed prior to 1977) performed by the staff of the Civil Engineering and Geosciences Branch in the Division of Engineering of the office of Nuclea Reactor Regulation. For the containment structures, most of the information related to th degraded conditions came from the licensees as part of the Licensing Event Report System (10 CFR 50.73), or as part of the requirement under limiting condition of operation of the plant-specific Technical Specifications. Most of the information related to the degradation of other structures and civil engineering features was extracted from the industry survey, the reported incidents, and the plant visits. The report discusses the condition of the structures and civil engineering features at operating nuclear power plants and provides information that would help detect, alleviate, and correct the degraded conditions of the structures and civil engineering features.

Assessment

Civil Engineering Features

Containment Structures

Containments

Degradations

Unlimited 14. SECURITY CLASSIFICATION

(This Page)

Unclassified (This Repor)

Unclassified

Inspection

Intake Structure

Structures

Water Control Structure
15. NUMBER OF PAGES

16. PRICE 